Prepared in cooperation with the Southwest Climate Science Center

\title{
Effects of Climate Change on Tidal Marshes along a Latitudinal Gradient in California
}

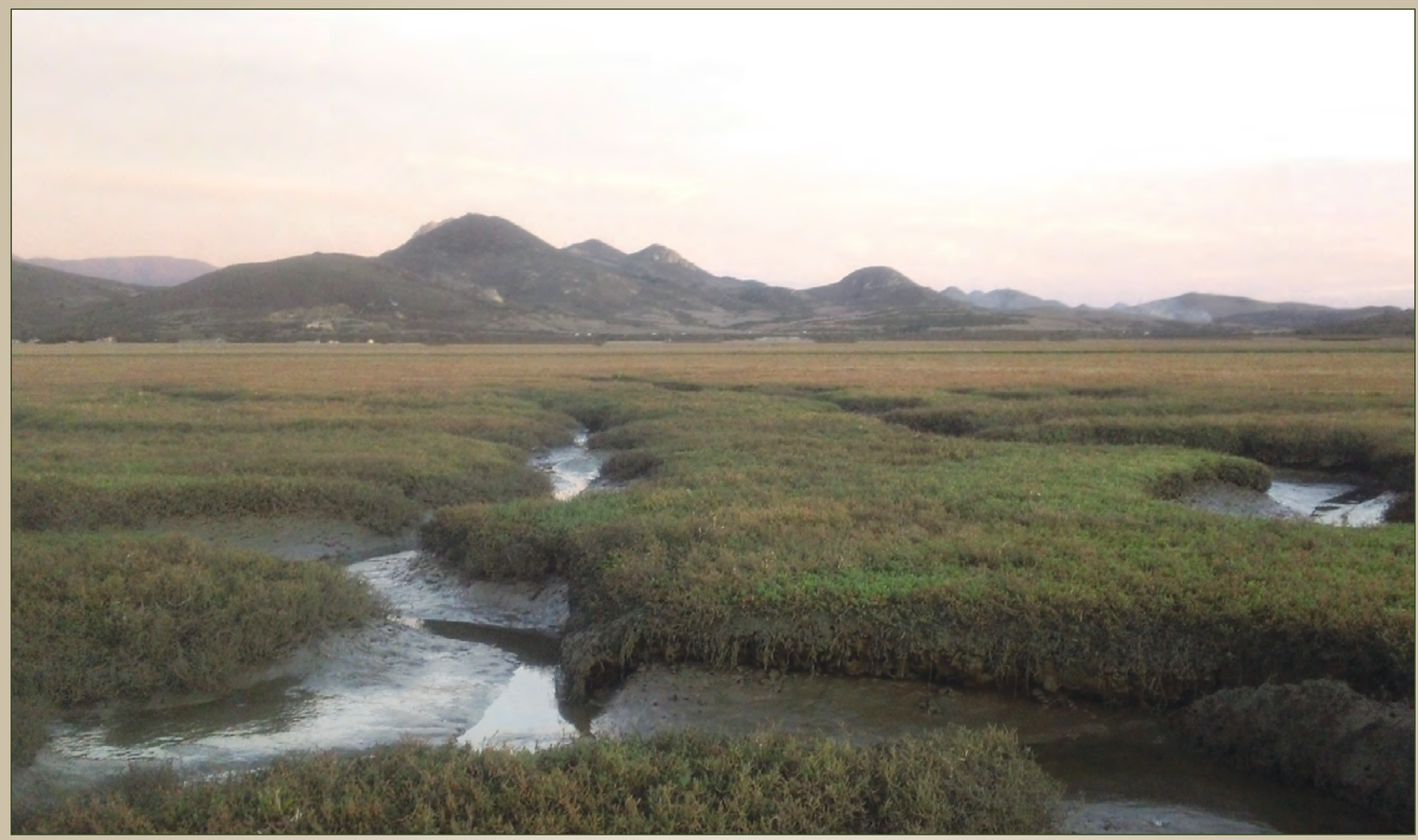

Open-File Report 2016-1125

U.S. Department of the Interior

U.S. Geological Survey 
Cover: Photograph showing Morro Bay Marsh with Cerro Cabrillo and Portola Point in the background, California, 2015. Photograph by Chase Freeman, U.S. Geological Survey. 


\section{Effects of Climate Change on Tidal Marshes along a Latitudinal Gradient in California}

By Karen M. Thorne, Glen M. MacDonald, Rich F. Ambrose, Kevin J. Buffington, Chase M. Freeman, Christopher N. Janousek, Lauren N. Brown, James R. Holmquist, Glenn R. Guntenspergen, Katherine W. Powelson, Patrick L. Barnard, and John Y. Takekawa

Prepared in cooperation with the Southwest Climate Science Center

Open-File Report 2016-1125

U.S. Department of the Interior

U.S. Geological Survey 


\section{U.S. Department of the Interior \\ SALLY JEWELL, Secretary}

\section{U.S. Geological Survey \\ Suzette M. Kimball, Director}

U.S. Geological Survey, Reston, Virginia: 2016

For more information on the USGS-the Federal source for science about the Earth, its natural and living resources, natural hazards, and the environment-visit http://www.usgs.gov/ or call 1-888-ASK-USGS (1-888-275-8747).

For an overview of USGS information products, including maps, imagery, and publications, visit http://store.usgs.gov.

Any use of trade, firm, or product names is for descriptive purposes only and does not imply endorsement by the U.S. Government.

Although this information product, for the most part, is in the public domain, it also may contain copyrighted materials as noted in the text. Permission to reproduce copyrighted items must be secured from the copyright owner.

Suggested citation:

Thorne, K.M., MacDonald, G.M., Ambrose, R.F., Buffington, K.J., Freeman, C.M., Janousek, C.N., Brown, L.N., Holmquist, J.R., Gutenspergen, G.R., Powelson, K.W., Barnard, P.L., and Takekawa, J.Y., 2016, Effects of climate change on tidal marshes along a latitudinal gradient in California: U.S. Geological Survey Open-File Report 2016-1125, 75 p., http://dx.doi.org/10.3133/ofr20161125.

ISSN 2331-1258 (online) 


\section{Contents}

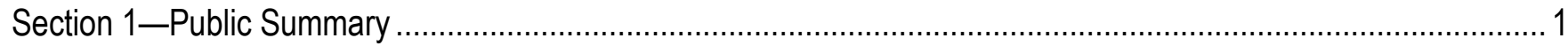

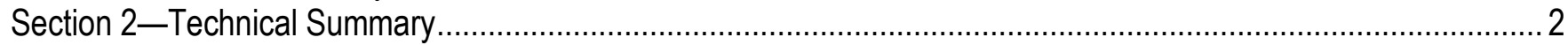

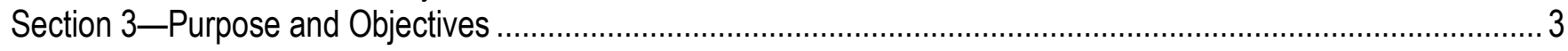

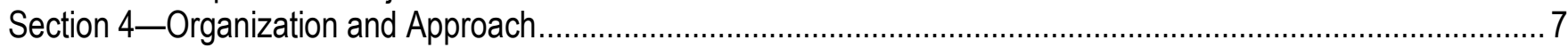

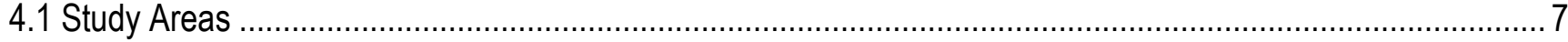

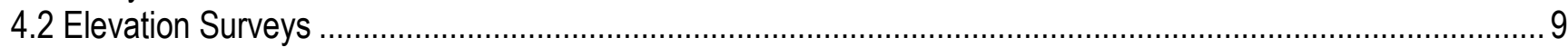

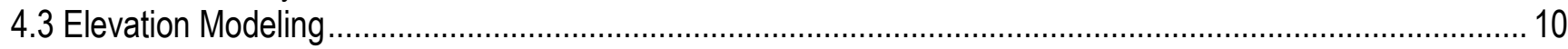

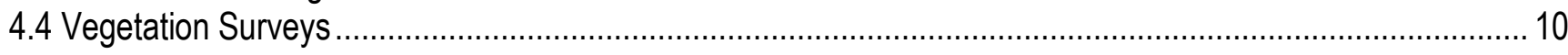

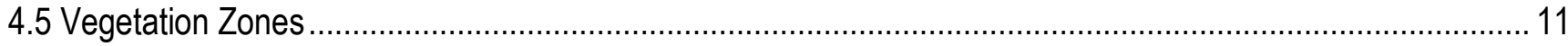

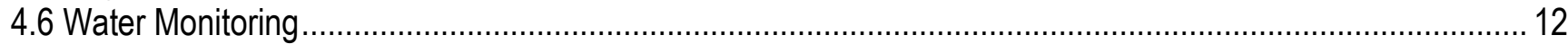

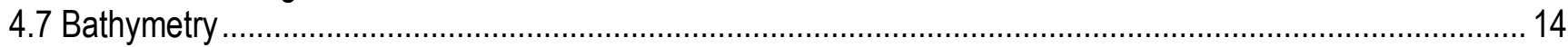

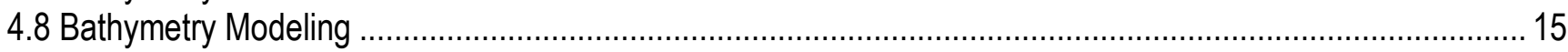

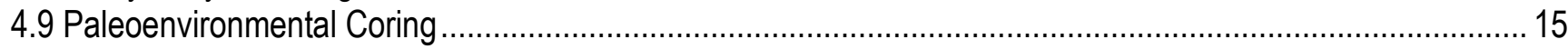

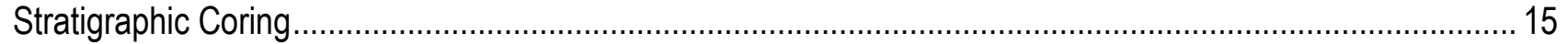

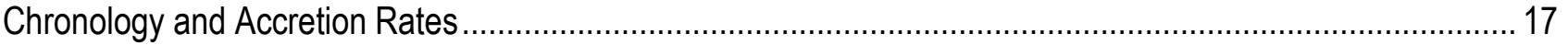

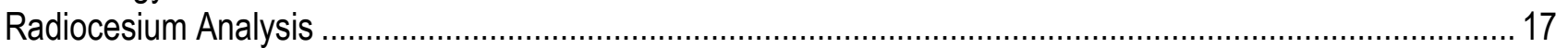

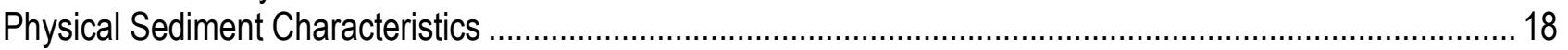

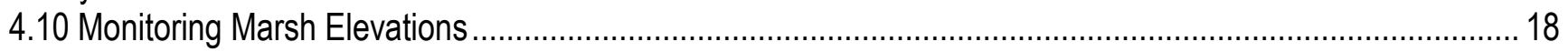

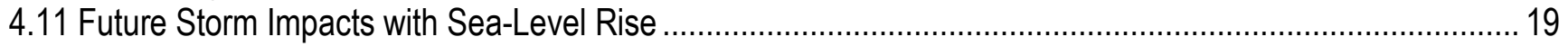

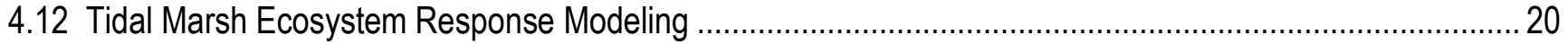

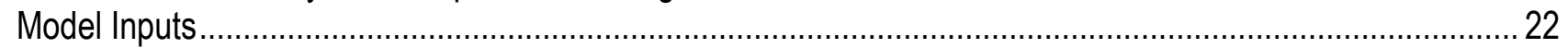

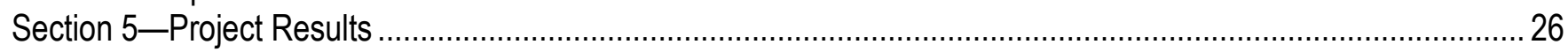

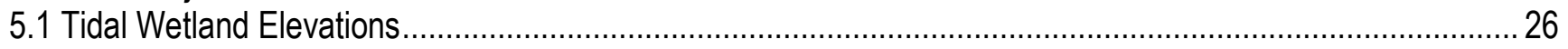

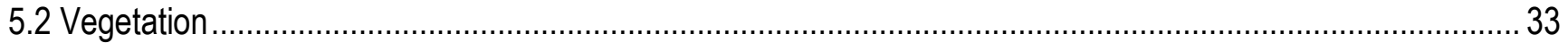

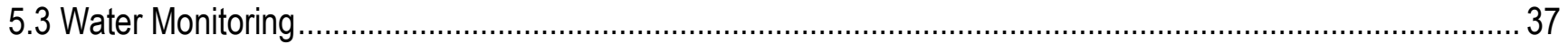

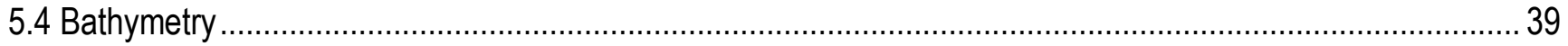

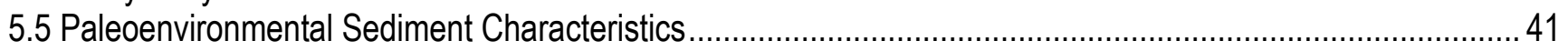

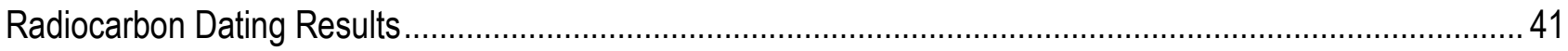

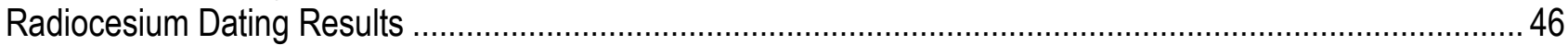

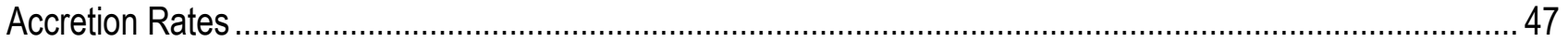

Long-Term Accretion Relative to Sea-Level Rise .............................................................................. 51

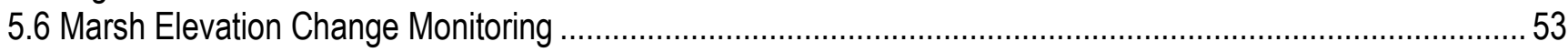

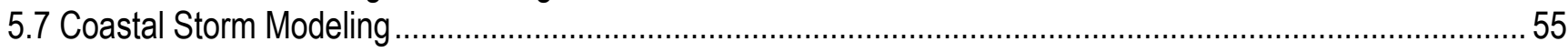

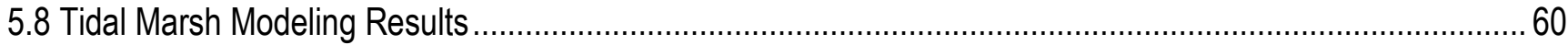

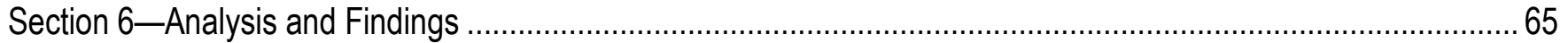

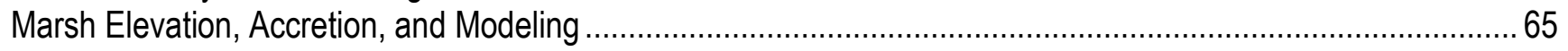

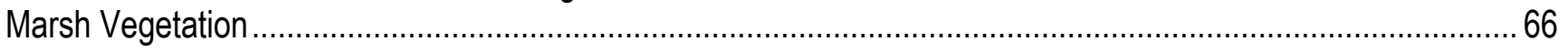

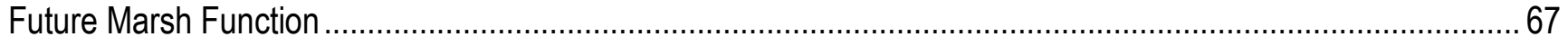

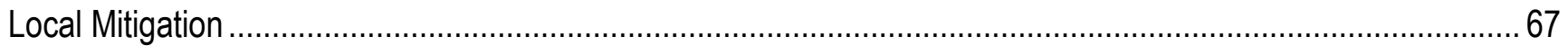

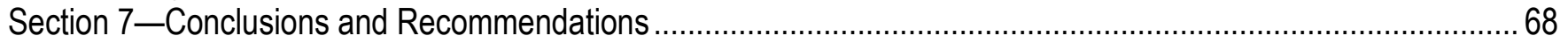

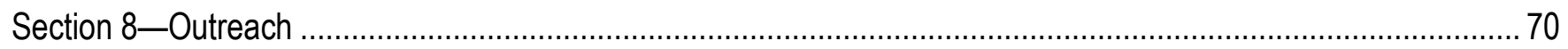

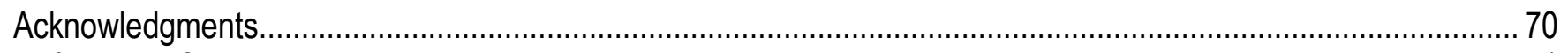

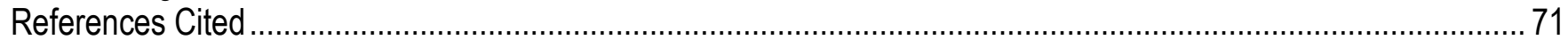

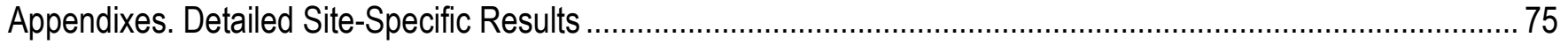




\section{Figures}

Figure 1. Conceptual model of linkages among physical and biological processes along the coast to assess climate-induced changes.

Figure 2. Seventeen project study sites that make up the Coastal Ecosystem Response to Climate Change (CERCC) program network, located within the boundaries of the North Pacific and California Landscape Conservation Cooperatives (LCCs)

Figure 3. California study sites in the U.S. Geological Survey Coastal Ecosystem Response to Climate Change (CERCC) network along a latitudinal gradient

Figure 4. U.S. Geological Survey technician collects elevation data using a Real-Time Kinematic Global Positioning System at Mad River Slough Study site, northern California

Figure 5. U.S. Geological Survey technicians collecting vegetation data at the San Pablo Bay National Wildlife Refuge, northern California.

Figure 6. Water-level logger in secondary channel at a California study-site marsh

Figure 7. U.S. Geological Survey technician conducting bathymetric surveys at San Pablo Bay National Wildlife Refuge, northern California.

Figure 8. Location of six California coastal marsh sites where soil cores were collected.

Figure 9. U.S. Geological Survey technicians from Patuxent Wildlife Research Center and Western Ecological Research Center installing a Surface Elevation Table at Morro Bay, central California...

Figure 10. Conceptual diagram showing how the soil profile is measured by Surface Elevation Table and marker horizon techniques to assess different processes in marsh soils (from Cahoon and others, 2002) ...... 19 Figure 11. WARMER one-dimensional cohort conceptual model of wetland accretion showing input variables for the modeling approach (Swanson and others, 2014).

Figure 12. Annual sediment accumulation function with elevation curves (lines) and measured accumulation rates (points) at six study sites in California.

Figure 13. Organic matter accumulation function with elevation (lines) and measured accumulation rates (points) at six study sites in California.

Figure 14. Density of marsh surface elevation measurements relative to mean higher high water (MHHW) across the seven study sites, California. 28

Figure 15. Boxplot showing distribution of marsh surface elevation data points across all seven California study sites (in meters [m] relative to mean higher high water [MHHW])

Figure 16. Cumulative frequency distribution of marsh elevation points relative to mean higher high water (MHHW, in meters [m]) across seven study sites, California

Figure 17. Tidal marsh digital elevation models across the seven study sites in the Coastal Ecosystem

Response to Climate Change network, California.

Figure 18. Distribution of tidal marsh vegetation zones across the seven study sites in the Coastal Ecosystem Response to Climate Change network, California

Figure 19. Frequency of occurrence (percentage of all vegetation plots [\%]) of six dominant and sub-dominant marsh species across six marshes in California.

Figure 20. Mean ( \pm standard deviation) vascular plant richness (species [spp.] per 0.25 square meters [ $\left.\mathrm{m}^{2}\right]$ ) in vegetation plots at six sites in California

Figure 21. Weekly maximum salinity levels of all study sites where data were available, California, November 2013-June2014

Figure 22. Bathymetry coverage across six study sites in California

Figure 23. Boxplot showing site-specific ranges of long-term accretion rates compared with past and projected rates of sea-level rise (SLR) at seven California study sites. 
Figure 24. U.S. Geological Survey technician measuring surface elevation change at a Surface Elevation Table, Mad River, Humboldt Bay, northern California..

Figure 25. Overview of the study area for Coastal Storm Modeling System (CoSMoS) 1.0 in southern

California, with locations of wave buoys (triangles) and water-level stations (squares) described in section 5.7,"Coastal Storm Modeling" (modified from Barnard and others, 2009).

Figure 26. Nearshore water-level model-data from the water-level station for the storm hindcast (see fig.

25 for location), La Jolla, California, January 2010.

Figure 27. Flooding projected for three southern California study sites (Pt. Mugu, Newport, and Tijuana)

for the January 2010 storm and the overlaid sea-level rise (SLR) scenarios

Figure 29. Projected changes in habitat composition under the National Research Council mid sea-level

rise (SLR) scenario (63 centimeters [cm] for Mad River; $93 \mathrm{~cm}$ for all other California study sites), 2010-2110.

CERCC, Coastal Ecosystem Response to Climate Change.

Figure 30. Projected changes in habitat composition under the National Research Council high

sea-level rise (SLR) scenario (142 centimeters [cm] for Mad River; $166 \mathrm{~cm}$ for all other California

study sites), 2010-2110. CERCC, Coastal Ecosystem Response to Climate Change

\section{Tables}

Table 1. National Geodetic Survey benchmarks used to verify rover accuracy in elevation surveys (published elevation minus measured elevation)

Table 2. Water-level logger deployments at California study sites

Table 3. WARMER model parameters and soil core characteristics used for model calibration across California study sites.

Table 4. Sample size, mean elevation and elevation range of Real Time Kinetic Global Positioning System elevation points collected at all study sites in the California Coastal Ecosystem Response to Climate Change network.

Table 5. Number of vegetation plots (upland plots excluded) and total tidal marsh vascular plant richness across six study sites in California

Table 6. Tidal datums calculated from water-level loggers deployed at each study site in California......

Table 7. Surveyed area and maximum and minimum elevations of nearshore habitat for six study sites in

California

Table 8. Collection data for 55 paleoenvironmental cores sampled for study sites in California 42

Table 9. Collection data for radiocesium samples taken from five cores from four study sites in California. 46

Table 10. Collection data for 71 radiocarbon samples taken from 37 cores and submitted to the University of California, Irvine, Keck Carbon Cycle Accelerator Mass Spectrometry Laboratory for analysis 48

Table 11. Mean long-term accretion rates calculated from radiocarbon, and short-term accretion rates calculated from radiocesium collection data for six study sites in California

Table 12. Average cumulative net change in marsh surface elevation at Surface Elevation Table locations in California tidal marshes

Table 13. Relative influence of key model parameters on final elevation in the WARMER modeling...... 64

Table 14. Three California workshops to disseminate site-specific sea-level rise modeling results were hosted by the U.S. Geological Survey to engage resource managers and their partner...... 


\section{Conversion Factors}

Inch/Pound to International System of Units

\begin{tabular}{|c|c|c|}
\hline Multiply & By & To obtain \\
\hline \multicolumn{3}{|c|}{ Length } \\
\hline mile (mi) & 1.609 & kilometer $(\mathrm{km})$ \\
\hline \multicolumn{3}{|l|}{ International System of Units to Inch/Pound } \\
\hline Multiply & By & To obtain \\
\hline \multicolumn{3}{|c|}{ Length } \\
\hline centimeter $(\mathrm{cm})$ & 0.3937 & inch (in.) \\
\hline meter $(\mathrm{m})$ & 3.281 & foot $(\mathrm{ft})$ \\
\hline kilometer $(\mathrm{km})$ & 0.6214 & mile (mi) \\
\hline \multicolumn{3}{|c|}{ Area } \\
\hline square meter $\left(\mathrm{m}^{2}\right)$ & 0.0002471 & acre \\
\hline hectare (ha) & 2.471 & acre \\
\hline square hectometer $\left(\mathrm{hm}^{2}\right)$ & 2.471 & acre \\
\hline square meter $\left(\mathrm{m}^{2}\right)$ & 10.76 & square foot $\left(\mathrm{ft}^{2}\right)$ \\
\hline hectare (ha) & 0.003861 & square mile $\left(\mathrm{mi}^{2}\right)$ \\
\hline \multicolumn{3}{|c|}{ Volume } \\
\hline cubic centimeter $\left(\mathrm{cm}^{3}\right)$ & 0.06102 & cubic inch $\left(\mathrm{in}^{3}\right)$ \\
\hline \multicolumn{3}{|c|}{ Sediment accretion rate } \\
\hline millimeter per year (mm/yr) & 0.03937 & inch per year (in/yr) \\
\hline \multicolumn{3}{|c|}{ Mass } \\
\hline $\operatorname{gram}(\mathrm{g})$ & 0.03527 & ounce, avoirdupois (oz) \\
\hline kilogram (kg) & 2.205 & pound avoirdupois (lb) \\
\hline \multicolumn{3}{|c|}{ Sediment accumulation rate } \\
\hline gram per centimeter per year $[(\mathrm{g} / \mathrm{cm}) / \mathrm{yr}]$ & 0.067196 & pound per foot per year \\
\hline \multicolumn{3}{|c|}{ Density } \\
\hline gram per cubic centimeter $\left(\mathrm{g} / \mathrm{cm}^{3}\right)$ & 62.4220 & pound per cubic foot $\left(\mathrm{lb} / \mathrm{ft}^{3}\right)$ \\
\hline
\end{tabular}

Temperature in degrees Celsius $\left({ }^{\circ} \mathrm{C}\right)$ may be converted to degrees Fahrenheit $\left({ }^{\circ} \mathrm{F}\right)$ as ${ }^{\circ} \mathrm{F}=\left(1.8 \times{ }^{\circ} \mathrm{C}\right)+32$.

\section{Datums}

Vertical coordinate information is referenced to North American Vertical Datum of 1988 (NAVD 88).

Horizontal coordinate information is referenced to North American Datum of 1983 (NAD 83).

Elevation, as used in this report, refers to distance above the vertical datum. 


\section{Abbreviations}

\begin{tabular}{|c|c|}
\hline AMS & accelerator mass spectrometer \\
\hline BRT & boosted regression tree \\
\hline cal & calibrated \\
\hline CcsM4 & Community Climate System Model version 4 \\
\hline C.E. & Common Era \\
\hline CERCC program & Coastal Ecosystem Response to Climate Change program \\
\hline CosMos & Coastal Storm Modeling System \\
\hline $\mathrm{CO}_{2}$ & carbon dioxide \\
\hline CSUMB & California State University, Monterey Bay \\
\hline GPS & Global Positioning System \\
\hline DEM & digital elevation model \\
\hline GCMs & General Circulation Models \\
\hline IPCC & Intergovernmental Panel on Climate Change \\
\hline IPCC-AR5 & IPCC-Fifth Assessment Report \\
\hline HOWL & highest observed water level \\
\hline LCCs & Landscape Conservation Cooperatives \\
\hline MHW & mean high water \\
\hline MHHW & mean higher high water \\
\hline MLLW & Mean lower low water \\
\hline MSL & mean sea level \\
\hline MTL & mean tide level \\
\hline NARR & North American Regional Reanalysis \\
\hline NERR & National Estuarine Research Reserve \\
\hline NRC & National Research Council \\
\hline NOAA & National Oceanic and Atmospheric Administration \\
\hline P.E.A.R.L & Paleoecological Environmental Assessment and Research Laboratory \\
\hline RCP & representative concentration pathway \\
\hline RMS & root-mean-square \\
\hline RTK & Real Time Kinematic \\
\hline SET & Surface Elevation Table \\
\hline SLR & sea-level rise \\
\hline SML & Seafloor Mapping Lab \\
\hline USGS & U.S. Geological Survey \\
\hline YBP & years before present \\
\hline WRF & Weather Research and Forecasting Model 3.2 \\
\hline
\end{tabular}


This page left intentionally blank 


\section{Effects of Climate Change on Tidal Marshes along a Latitudinal Gradient in California}

By Karen M. Thorne1, Glen M. MacDonald2, Rich F. Ambrose², Kevin J. Buffington¹, Chase M. Freeman¹, Christopher N. Janousek¹, Lauren N. Brown², James R. Holmquist², Glenn R. Guntenspergen¹, Katherine W. Powelson'1, Patrick L. Barnard1', and John Y. Takekawa1

\section{Section 1-Public Summary}

The coastal region of California supports a wealth of ecosystem services including habitat provision for wildlife and fisheries. Tidal marshes, mudflats, and shallow bays within coastal estuaries link marine, freshwater and terrestrial habitats, and provide economic and recreational benefits to local communities. Climate change effects such as sea-level rise (SLR) are altering these habitats, but we know little about how these areas will change over the next 50-100 years. Our study examined the projected effects of three recent SLR scenarios produced for the West Coast of North America on tidal marshes in California. We compiled physical and biological data, including coastal topography, tidal inundation, plant composition, and sediment accretion to project how SLR may alter these ecosystems in the future. The goal of our research was to provide results that support coastal management and conservation efforts across California. Under a low SLR scenario, all study sites remained vegetated tidal wetlands, with most sites showing little elevation and vegetation change relative to sea level. At most sites, mid SLR projections led to increases in low marsh habitat at the expense of middle and high marsh habitat. Marshes at Morro Bay and Tijuana River Estuary were the most vulnerable to mid SLR with many areas becoming intertidal mudflat. Under a high SLR scenario, most sites were projected to lose vegetated habitat, eventually converting to intertidal mudflats. Our results suggest that California marshes are vulnerable to major habitat shifts under mid or high rates of SLR, especially in the latter part of the century. Loss of vegetated tidal marshes in California due to SLR is expected to impact ecosystem services that are dependent on coastal wetlands such as wildlife habitat, carbon sequestration, improved water quality, and coastal protection from storms.

\footnotetext{
${ }^{1}$ U.S. Geological Survey.

${ }^{2}$ University of California, Los Angeles.
} 


\section{Section 2-Technical Summary}

Climate change presents challenges and uncertainties for coastal land managers planning for the conservation and management of estuarine habitats and natural resources. As transitional ecotones between the marine and terrestrial environment, estuaries and their tidal marshes may be affected by multiple climate-change impacts. Projected climate change effects on coastal environments include SLR, changing storm magnitude and frequency, saltwater intrusion, accelerated coastal erosion, shifting mudflat profiles, and increasing water temperature and acidification. We intensively sampled baseline conditions at selected sites along the California coastline to assess the vulnerability of tidal marsh habitats to future SLR and coastal storms. Our overarching questions were:

1. How vulnerable are California tidal marshes to different rates of SLR?

2. Does tidal marsh susceptibility to SLR vary along a latitudinal gradient and between estuaries?

3. We addressed these questions with four specific objectives:

4. Assess past climates to inform near-future projections,

Measure morphological and ecological characteristics of the marshes (for example, elevation, tidal range, hydrology, and vegetation composition) across the habitat continuum,

1. Model tidal marsh elevation and habitat change with SLR, and

2. Examine spatial variability of these projected changes along a latitudinal gradient.

Across our study sites, we found differences in baseline topography, vegetation, soil characteristics, salinity, and tide range. Our modeling suggested that marsh vulnerability was dependent on initial elevation, accretion rates, and rate of SLR by 2110. Most study sites maintained their elevation relative to sea level under the lowest SLR scenario with little loss of vegetated marsh. However, under mid and high SLR rates, marsh vertical growth did not keep pace with SLR and habitat proportions at the site shifted (high and middle marsh zones usually became low marsh or the site transitioned to intertidal mudflats). All study sites were highly vulnerable to a high SLR scenario, losing all vegetated habitat by 2110 . However, the timing of habitat change varied across sites.

Our research products include site-specific baseline data for managers and projections of tidal marsh vulnerability under three SLR scenarios for California. Our findings are timely for local and regional resource managers and policy makers who need to develop future climate change adaptation plans to sustain coastal wetland ecosystem functions and services. 


\section{Section 3-Purpose and Objectives}

Climate change threatens to affect the productivity and diversity of coastal ecosystems by altering nearshore physical and biological systems (Intergovernmental Panel on Climate Change, 2014). Effects on coastal environments include increased inundation from SLR and storms, saltwater intrusion, erosion, shifting beach and mudflat profiles, changes in water temperature, and acidification (Scavia and others, 2002; Huppert and others, 2009). Recent estimates of global SLR by the year 2100 range from 75 to $190 \mathrm{~cm}$ (Vermeer and Rahmstorf, 2009) to 54 to $71 \mathrm{~cm}$ (Slangen and others, 2014). In California south of Cape Mendocino, the National Research Council (hereinafter NRC) projected SLR rates between 42 and $167 \mathrm{~cm}$ over the coming century (National Research Council, 2012). Because of tectonic uplift, the NRC projected SLR rates between 12 and $143 \mathrm{~cm}$ by 2110 for the California coastline north of Cape Mendocino, including Humboldt Bay. At local spatial scales, realized SLR rates are affected by other factors including glacial rebound, regional tectonics, and ocean circulation patterns (National Research Council, 2012). Coastal ecosystems also face other pressures such as urban development, habitat fragmentation, altered hydrology, eutrophication, pollution, and introduction of non-native species (Gedan and others, 2009) that may exacerbate climate change effects on coastal productivity, biodiversity, and accretion potential (Kirwan and Megonigal, 2013).

Model projections of future global climate conditions and ecosystem response often are conducted at scales that are difficult to apply to local-scale management of coastal habitats. To obtain reliable estimates of impacts at smaller spatial scales, it is necessary to collect fine-scale information on environmental conditions and organism distributions and link them to regional SLR scenarios to help inform management decision making and planning. Understanding how regional dynamics currently affect local coastal ecosystems can help inform ecosystem management and identify habitats that are most vulnerable to climate change (fig. 1). To understand climate-induced changes to coastal ecosystems from the site to regional scale, we established the U.S. Geological Survey (USGS) Coastal Ecosystem Response to Climate Change (CERCC) program, with eight California sites distributed from Humboldt Bay to San Diego Bay. The CERCC program also includes nine companion sites in the Pacific Northwest (fig. 2). The program is led by the USGS, Western Ecological Research Center; the University of California, Los Angeles' Oregon State University; and local management agencies. Our broad geographic focus across multiple estuaries allows a more robust assessment of SLR vulnerability. Regional and local understanding will be essential in developing comprehensive vulnerability assessments for long-term conservation and management of coastal habitats, and development of climate adaptation strategies by managers and decision makers. 


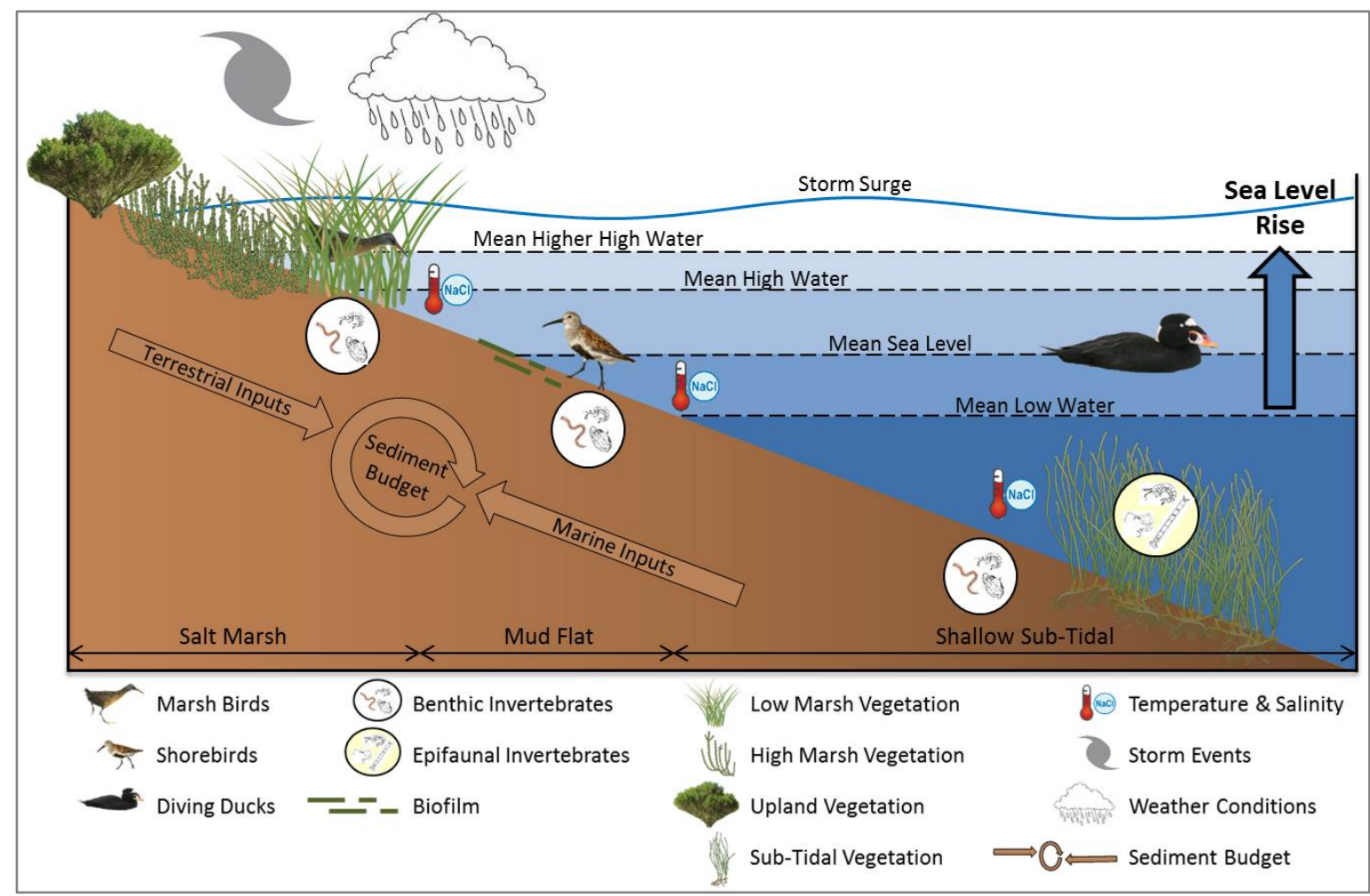

Figure 1. Conceptual model of linkages among physical and biological processes along the coast to assess climate-induced changes. 


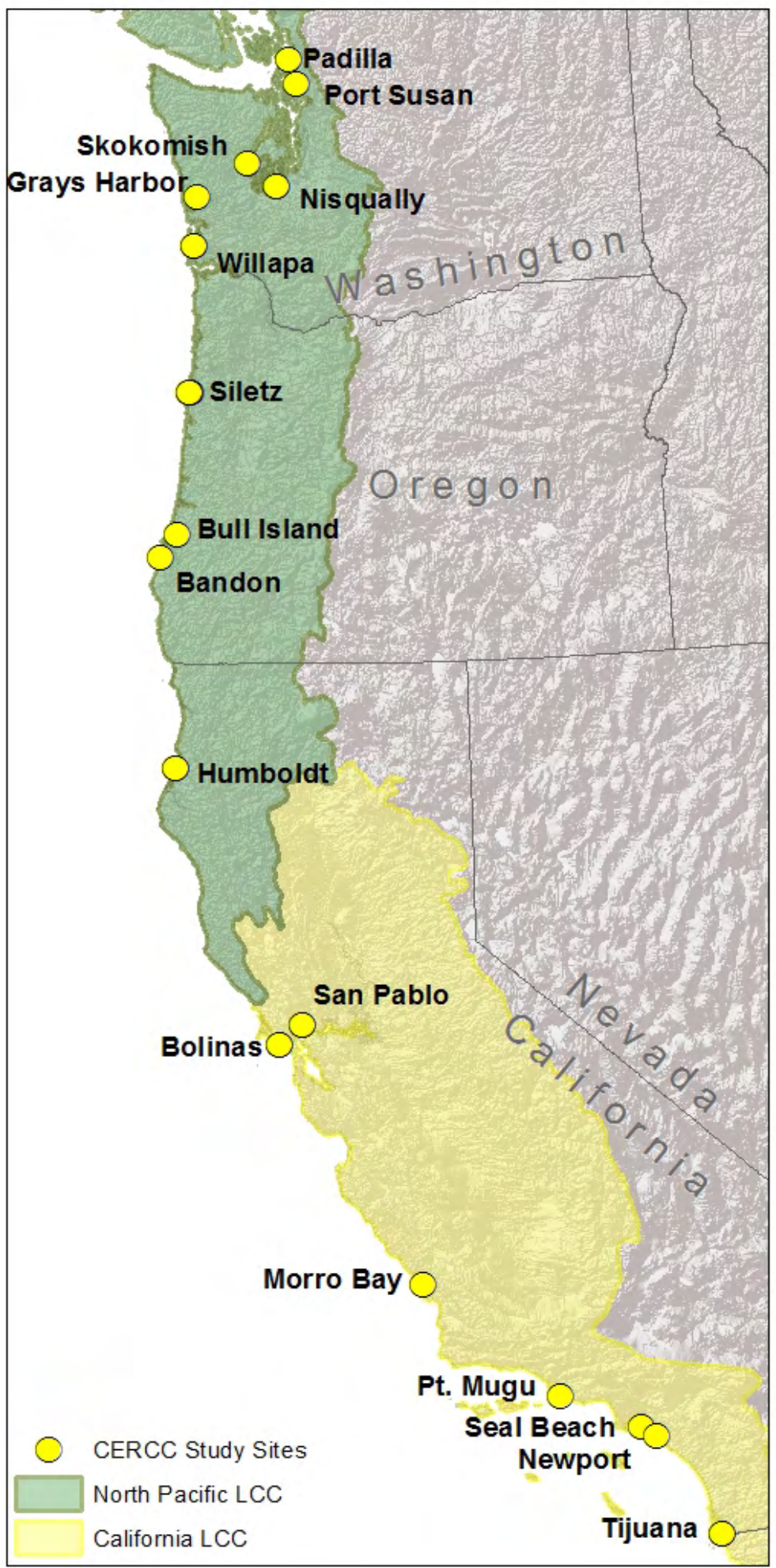

Figure 2. Seventeen project study sites that make up the Coastal Ecosystem Response to Climate Change (CERCC) program network, located within the boundaries of the North Pacific and California Landscape Conservation Cooperatives (LCCs). 
Our research is relevant to several ongoing Federal research priorities to understand climateinduced changes to ecosystems. For instance, our work addresses the priority goals established in "Rising to the Urgent Challenge," a document developed by the U.S. Fish and Wildlife Service (2010) to establish their strategic climate change plan and assist managers in developing adaptation and planning strategies. Additionally, our research helps meet one of the priority objectives in the U.S. Department of the Interior (National Fish, Wildlife and Plants Climate Adaptation Partnership, 2012), developed as a collaborative effort mandated by Congress (P.I. Thorne, coastal development team member, oral commun., 2012). This research is a key science-management need identified by the California and North Pacific Landscape Conservation Cooperatives (LCCs). Our data provide information needed to increase preparedness of resource managers (for example, U.S. Fish and Wildlife Service, National Park Service, National Oceanic and Atmospheric Administration [NOAA], National Estuarine Research Reserve [NERR], California Department of Fish and Wildlife, and California State Parks) who address species and habitat restoration and management. Finally, these results address the USGS Science Strategy, which includes anticipating and assessing ecosystem response to climate change.

At the State level, California has highlighted coastal ecosystems as important areas susceptible to climate change and has prioritized research to assist in adaptation planning for resource management and ecosystem services (for example, State Wildlife Action Plans, California Natural Resources Agency, 2010). The information emerging from this work will provide local managers and decision makers with the information they need to address endangered and threatened species management, wetland restoration, and recovery plans while making informed decisions on habitat resiliency and land acquisition that effectively consider the effects of climate change on their habitats.

The broad goal of our research was to use site-specific data to develop local and regionally applicable models that inform management of tidal wetlands along the California coast. Our overarching questions were:

1. How vulnerable are California tidal marshes to different rates of SLR?

2. Does tidal marsh susceptibility to SLR vary between estuaries and along a coastal latitudinal gradient?

These questions were addressed with four broad objectives:

1. Assess past patterns in sedimentation to inform current SLR projections. This was accomplished by radioisotope dating of stratigraphic cores.

2. Measure baseline conditions in the tidal marshes. We characterized physical and biological properties at all study sites including topography, accretion rates, emergent vegetation, water level, salinity, and water temperature. We are monitoring current elevation change with Surface Elevation Tables (SETs) at all sites.

3. Model tidal marsh elevation and habitat change under three SLR scenarios. We evaluated the degree of marsh habitat change under low, mid, and high SLR scenarios with the WARMER model (Swanson and others, 2013) for all study sites. We also assessed storm and SLR flooding risk using the Coastal Storm Modeling System (CoSMoS) with General Circulation Models (GCMs) driven by representative concentration pathways (RCPs) radiative forcing scenarios created for the Intergovernmental Panel on Climate Change (IPCC) Fifth Assessment Report (AR5) at each study area (Barnard and others, 2014). CoSMoS provided local information on future wave impacts and coastal inundation under a range of SLR and storm scenarios for tidal marshes at Point Mugu Lagoon, Newport Bay, and Tijuana River Estuary.

4. Examine spatial variability of projected SLR impacts along a latitudinal gradient. 


\section{Section 4-Organization and Approach}

\subsection{Study Areas}

The research was conducted between 2012 and 2014 at seven coastal estuaries from Humboldt Bay in northern California to Tijuana Estuary adjacent to the United States-Mexico border (fig. 3), including Mad River Slough in Humboldt Bay National Wildlife Refuge (hereinafter Mad River); San Pablo Bay National Wildlife Refuge in northern San Francisco Bay (hereinafter San Pablo); Bolinas Lagoon (hereinafter Bolinas); Morro Bay State Park, a National Estuary Program site (hereinafter Morro); Point Mugu Lagoon located at Naval Air Station Point Mugu (hereinafter Pt. Mugu); Upper Newport Bay (hereinafter Newport); and Tijuana Slough National Wildlife Refuge/Tijuana River National Estuarine Research Reserve (hereinafter Tijuana). Each study site contained areas of both tidal marsh and adjacent mudflat present in the local estuary. Although most of the California coast has a Mediterranean climate, the sites spanned a range of climate and oceanographic conditions. For instance, air and water temperatures are lower and annual precipitation is higher in the northern parts of California than in the southern parts; northern parts of California are defined as a transitional temperate/maritime climate. Overall tidal range decreased from northern to southern California. 


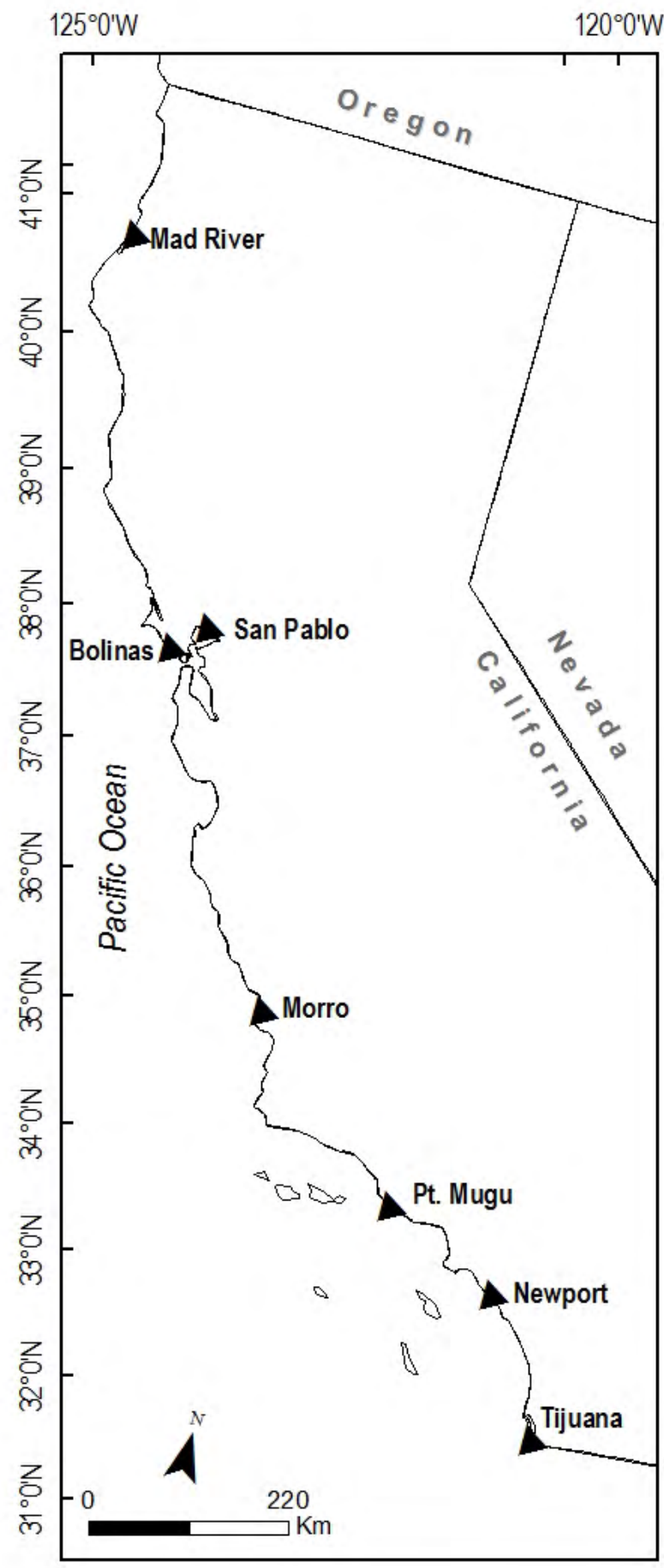

Figure 3. California study sites in the U.S. Geological Survey Coastal Ecosystem Response to Climate Change (CERCC) network along a latitudinal gradient. 


\subsection{Elevation Surveys}

To assess the current topography of the tidal marsh study sites, we conducted survey-grade elevation surveys at all sites between 2009 and 2013 using a Leica RX1200 Real Time Kinematic (RTK) Global Positioning System (GPS) rover $( \pm 1 \mathrm{~cm}$ horizontal, $\pm 2 \mathrm{~cm}$ vertical accuracy; Leica Geosystems Inc., Norcross, Georgia; fig. 4). At sites with RTK GPS network coverage (San Pablo, Pt. Mugu, and Newport), rover positions were received in real time from the Leica Smartnet system using a CDMA modem (http://www.leica-geosystems.us/en/index.htm). At sites without network coverage (Humboldt, Bolinas, Morro and Tijuana), rover positions were received in real time from a Leica GS10 antenna base station by radio link. When using the base station, we adjusted all elevation measurements using an OPUS correction (http://www.ngs.noaa.gov/OPUS/). We used the WGS 84 ellipsoid model for vertical and horizontal positioning. We verified rover accuracy and precision by measuring positions at local National Geodetic Survey benchmarks and temporary benchmarks established at each site (table 1). The average measured vertical error at benchmarks was $2.2 \mathrm{~cm}$ across the sites, which is comparable to the stated error of the GPS.

At each site, we surveyed marsh surface elevation along transects oriented perpendicular to the major tidal sediment source, with a survey point taken every $12.5 \mathrm{~m} ; 50 \mathrm{~m}$ separated transect lines (fig. A1-G1). We used the Geoid09 model to calculate orthometric heights from ellipsoid values (in meters, North American Vertical Datum of 1988 [NAVD 88]) and projected all points to North American Datum of 1983 [NAD 83] UTM zone 10 or zone 11 using Leica GeoOffice v7.0.1 (Leica Geosystems Inc., Norcross, Georgia).

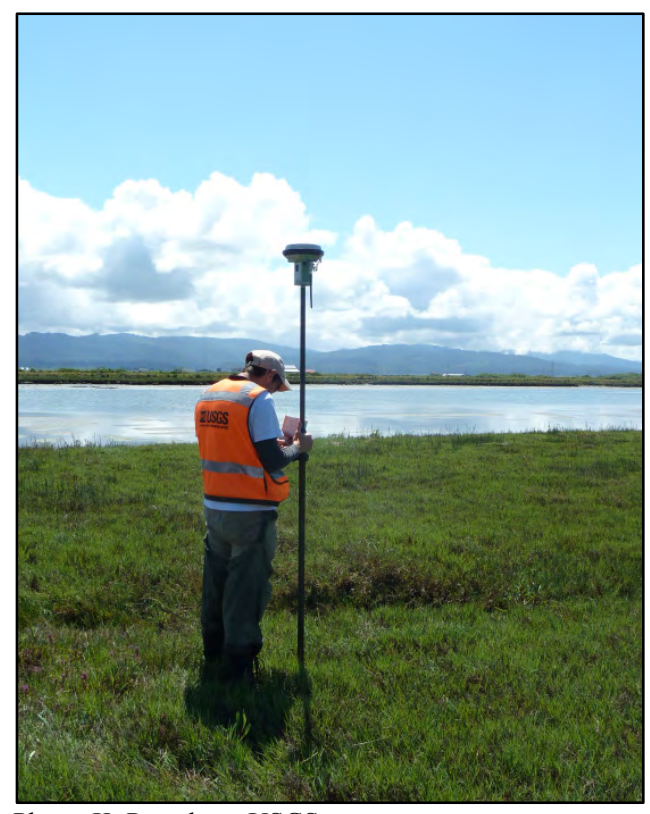

Photo: K. Powelson, USGS

Figure 4. U.S. Geological Survey technician collects elevation data using a Real-Time Kinematic Global Positioning System at Mad River Slough Study site, northern California. 
Table 1. National Geodetic Survey benchmarks used to verify rover accuracy in elevation surveys (published elevation minus measured elevation).

[Sites are ordered from north to south. PID, Permanent Identifier; RTK, Real-Time Kinematic]

\begin{tabular}{llllll}
\hline \multicolumn{1}{c}{ Site } & \multicolumn{1}{c}{$\begin{array}{c}\text { Benchmark } \\
\text { PID }\end{array}$} & \multicolumn{1}{c}{ Latitude (N) } & Longitude (W) & $\begin{array}{c}\text { Average error } \\
\text { (meters) }\end{array}$ & \multicolumn{1}{c}{$\begin{array}{c}\text { Survey } \\
\text { methodology }\end{array}$} \\
\hline Mad River & LV0346 & $40^{\circ} 51^{\prime} 54^{\prime \prime}$ & $124^{\circ} 09^{\prime} 00^{\prime \prime}$ & 0.002 & Base station \\
San Pablo & JT0321 & $38^{\circ} 06^{\prime} 26^{\prime \prime}$ & $122^{\circ} 17^{\prime} 13^{\prime \prime}$ & 0.03 & RTK network \\
Bolinas & BOLYBAY01 $^{1}$ & $37^{\circ} 55^{\prime} 50^{\prime \prime}$ & $122^{\circ} 41^{\prime} 20^{\prime \prime}$ & 0.001 & Base station \\
Morro & FV1099 & $35^{\circ} 22^{\prime} 02^{\prime \prime}$ & $120^{\circ} 50^{\prime} 02^{\prime \prime}$ & 0.01 & Base station \\
Pt. Mugu & EW6523 & $34^{\circ} 07^{\prime} 00^{\prime \prime}$ & $119^{\circ} 05^{\prime} 08^{\prime \prime}$ & 0.06 & RTK network \\
Newport & AD9435 & $33^{\circ} 39^{\prime} 52^{\prime \prime}$ & $117^{\circ} 52^{\prime} 31^{\prime \prime}$ & 0.01 & RTK network \\
\hline Tijuana & B899 & $32^{\circ} 35^{\prime} 38^{\prime \prime}$ & $117^{\circ} 07^{\prime} 21^{\prime \prime}$ & 0.04 & Base station \\
\hline
\end{tabular}

${ }^{1}$ The BOLYBAY01 benchmark surveyed by U.S. Army Corps of Engineers, San Francisco District, Hydrographic Survey Section, May 31, 2012. Results are in an unpublished document entitled, "Final Survey Report—Bolinas Lagoon Ecosystem Restoration Control.”

\subsection{Elevation Modeling}

We synthesized the elevation survey data to create a digital elevation model (DEM) at each site in ArcGIS ${ }^{\mathrm{TM}}$ 10.2.1 Spatial Analyst (Environmental Systems Research Institute, Incorporated, 2013, Redlands, California) with exponential ordinary kriging methods (5×5-m cell size) after adjusting model parameters to minimize the root-mean-square error (RMS). We used elevation models as the baseline conditions for subsequent analyses, including tidal inundation patterns, SLR response modeling, and mapping of sites by specific elevation (flooding) zones.

In this report, we present elevation data as both local orthometric heights (NAVD 88) and local mean higher high water (MHHW), based on computation of site-specific MHHW from water-level data (described in section 4.6). For comparison of results among sites with different tidal ranges, we also standardized elevations to local tide range, using the $\mathrm{z}^{*}$ metric, where $\mathrm{z}^{*}=(\mathrm{z}$-mean tide level or MTL)/(MHHW-MTL) as described in Swanson and others (2014).

\subsection{Vegetation Surveys}

We assessed vegetation cover and species richness concurrently with elevation surveys at about 25 percent of the elevation points (fig. 5). We visually assessed percentage of cover of all plant species within a $0.25-\mathrm{m}^{2}$ quadrat, and recorded the average and maximum height (measured to the nearest centimeter) of each species. Total plant cover in a plot could exceed 100 percent because of vegetation layering. Vascular plant nomenclature generally follows Baldwin and others (2012). 


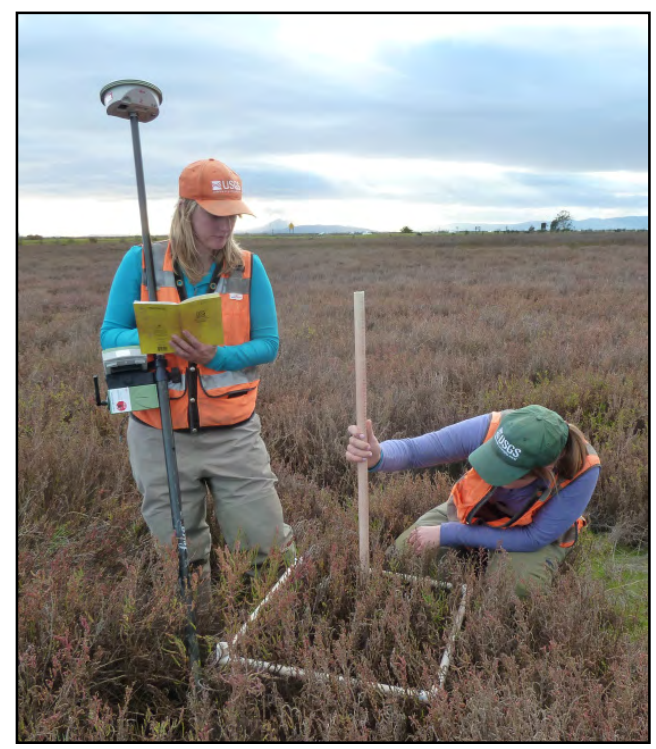

Photo: C. Freeman, USGS

Figure 5. U.S. Geological Survey technicians collecting vegetation data at the San Pablo Bay National Wildlife Refuge, northern California.

\subsection{Vegetation Zones}

We used long-term (10-year) NOAA tide data to assess inundation relationships with local elevation and thereby define the elevation limits of four intertidal habitat zones for evaluation of SLR impacts to marshes along the California coastline: low marsh, middle marsh, high marsh, and transitional marsh. First, to determine region-specific relationships between elevation and inundation, we compiled data from all recorded high tides from 2004 to 2013 at three NOAA tidal stations along the West Coast of the United States-San Diego, San Francisco, and Charleston, Oregon (http://tidesandcurrents.noaa.gov). Using these time series, we determined the percentage of high tides that reached a given elevation. We defined low marsh as all elevations between the lowest vegetation plot and the elevation reached by 50 percent of all recorded high tides (low marsh flooded at least once daily, on average). We defined middle marsh as habitat flooded by 50-25 percent of all high tides (flooding once every 1-2 days, on average), and high marsh as elevations flooded by 3-25 percent of all high tides (flooding at least twice per month, but less than once every other day, on average). We defined transition-zone marsh as habitat flooded by $0.14-3$ percent of all high tides (flooding at least once annually, but no more than twice per month, on average). Mudflat occurred between local mean lower low water (MLLW) and the lowest extent of emergent tidal marsh vegetation; subtidal habitat occurred below MLLW.

Using the regional NOAA data, we determined the $\mathrm{z}^{*}$ ranges that corresponded to the four marsh habitat zones defined in the preceding paragraph. We used San Diego long-term NOAA data for southern California sites (Tijuana, Newport, and Pt. Mugu), San Francisco data for sites in central California (Morro, San Pablo, Bolinas), and Charleston data for the Mad River site. Finally, using MHHW and MTL estimates specific to each study site, we converted the regional $z^{*}$ ranges of each zone to local NAVD 88 and MHHW ranges that corresponded with the defined habitat zones. 


\subsection{Water Monitoring}

We deployed 1-4 water-level loggers and a single conductivity logger at all sites over the study period (fig. 6; table 2). Primary water-level loggers and conductivity loggers were deployed in major tidal channels connecting the marshes to the estuary. Secondary water-level loggers were deployed in the upper reaches of second-order tidal channels to capture high tides and determine inundation patterns. Water-level readings were collected every 6 minutes. We used data from the primary water-level logger at each site to develop local hydrographs and inundation rates. Loggers were surveyed by RTK GPS at least once during the period of deployment. We corrected all raw water-level data with local time series of barometric pressure using Solinst ${ }^{\circledR}$ barometric loggers (Model 3001, Solinst ${ }^{\circledR}$ Canada Limited., Georgetown, Ontario, Canada), additional Hobo ${ }^{\circledR}$ loggers (Model U-20-001-01-Ti, Onset Computer Corporation, Bourne, Massachusetts), or barometric pressure from local airports (distance $<10 \mathrm{mi}$ ).

We assessed salinity and water temperature in the tidal channels at each site with Odyssey ${ }^{\mathrm{TM}}$ conductivity/temperature loggers (Dataflow Systems Pty Limited, Christchurch, New Zealand), after an initial period of unsuccessful deployment of Hobo ${ }^{\circledR}$ conductivity loggers (Model U-24-001, Onset Computer Corporation, Bourne, Massachusetts) that were recalled because of manufacture error and data inconsistencies. We converted specific conductance values obtained with the Odyssey ${ }^{\text {TM }}$ loggers to practical salinity units (PSU) using the equation in United Nations Educational, Scientific and Cultural Organization (1983). At Tijuana, we used salinity data from the Web site of the National Estuarine Research Reserve System Centralized Data Management Office, using the Boca Rio station (TJRBRWQ, $32.5595^{\circ} \mathrm{N}$ latitude, $-117.1288^{\circ} \mathrm{W}$ longitude; cdmo.baruch.sc.edu).

Water-level data were used to estimate local tidal datums for all sites with procedures outlined in the NOAA Tidal Datums Handbook (National Oceanic and Atmospheric Administration, 2003). Only local mean high water (MHW) and MHHW were calculated because the loggers were positioned in the intertidal zone, and therefore could not be used to compute lower datums. Mean tide level (MTL) was estimated for each site by using the NOAA VDATUM model (v.3.4) at the location of the primary water-level logger or at a nearby site in the estuary if the VDATUM model domain did not include the water-level logger location. At Bolinas, we used NOAA published values for MTL, MHW, and MHHW; the station was located about $2 \mathrm{~km}$ from the study site. 


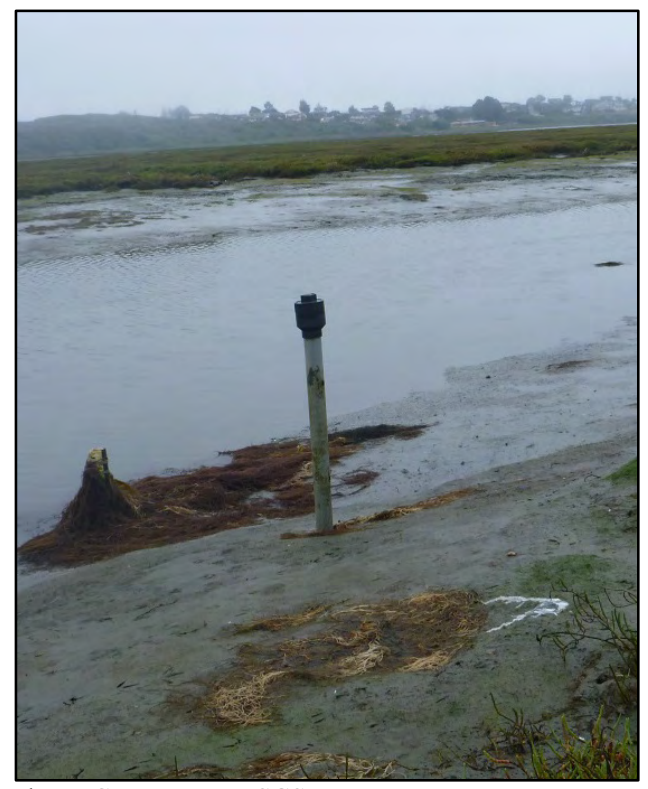

Photo: C. Freeman. USGS

Figure 6. Water-level logger in secondary channel at a California study-site marsh.

Table 2. Water-level logger deployments at California study sites.

[Sites are ordered from north to south. Manufacturer information, number of loggers currently deployed, and source of barometric pressure data for compensation varied across sites]

\begin{tabular}{llccl}
\hline Site & \multicolumn{1}{c}{$\begin{array}{c}\text { Date of } \\
\text { Deployment }\end{array}$} & $\begin{array}{c}\text { Water-level logger } \\
\text { manufacturer }\end{array}$ & $\begin{array}{c}\text { Number of water-level } \\
\text { loggers deployed }\end{array}$ & $\begin{array}{c}\text { Barometric pressure } \\
\text { compensation method }\end{array}$ \\
\hline Mad River & June 2012 & Solinst & 2 & On-site barologger \\
San Pablo & December 2009 & Solinst & 4 & On-site barologger \\
Bolinas & January 2013 & Hobo & 1 & On-site barologger \\
Morro & November 2013 & Hobo & 2 & On-site barologger \\
Pt. Mugu & January 2013 & Hobo & 2 & Point Mugu Naval Air Station data \\
Newport & December 2012 & Hobo & 2 & John Wayne Airport data \\
Tijuana & June 2012 & Solinst & 4 & On-site barologger \\
\hline
\end{tabular}




\subsection{Bathymetry}

We conducted bathymetric surveys using a shallow-water echo-sounding system (Takekawa and others, 2010, Brand and others, 2012) comprised of an acoustic profiler (Navisound 210, Reson, Inc., Slangerup, Denmark), Leica RTK GPS Viva rover, and laptop computer mounted on a shallow-draft, portable flat-bottom boat (Bass Hunter, Cabela's, Sidney, Nebraska; fig. 7). The RTK GPS obtained high-resolution elevations of the water surface (reported precision $<1 \mathrm{~cm}$; estimated accuracy $\pm 3 \mathrm{~cm}$ ). The rover positions were received from the Leica Smartnet system (http://www.lecia-geosystems.com) or base station and were referenced to the same benchmark used in the elevation surveys (table 1). The rover averaged $\pm 2.5 \mathrm{~cm}$ vertical error at the reference benchmark, which is within the stated error of the survey unit. We mounted a variable-frequency transducer on the front of the boat and connected it to the sounder; the sounder worked in areas with greater than $10 \mathrm{~cm}$ of water depth. We recorded 20 depth readings and 1 GPS location each second along transects spaced $100 \mathrm{~m}$ apart perpendicular to the nearby salt marsh. We calibrated the system before use with a bar-check plate and adjusted the sound velocity for salinity and temperature differences. We suspended the bar-check plate below the transducer at a known depth that was verified against the transducer readings. Morro Bay did not have bathymetry data; therefore, we downloaded lidar data collected by the NOAA California Coastal Conservancy Coastal TopoBathy Project_-Digital Elevation Model 2009-2011.

For bathymetry at Pt. Mugu, we used data collected by the Seafloor Mapping Lab (SFML) at California State University, Monterey Bay (CSUMB) (Seafloor Mapping Lab, 2013). Side scan data for Pt. Mugu were acquired using a Swathplus interferometric sonar with an Applanix Position and Orientation System, Marine Vessel (POS MV 320 v.4) system (position accuracy $\pm 2 \mathrm{~m}$, pitch, roll and heading accuracy $\pm 0.02^{\circ}$, heave accuracy \pm 5 percent or $5 \mathrm{~cm}$ ). Bathymetric data were post-processed using CARIS HIPS hydrographic data cleaning system software. Derived products are at 1-m resolution and relative to the NAVD 88 with geoid09. Data acquisition, post-processing, and final products derived from multibeam bathymetry data were handled by the SFML at CSUMB.

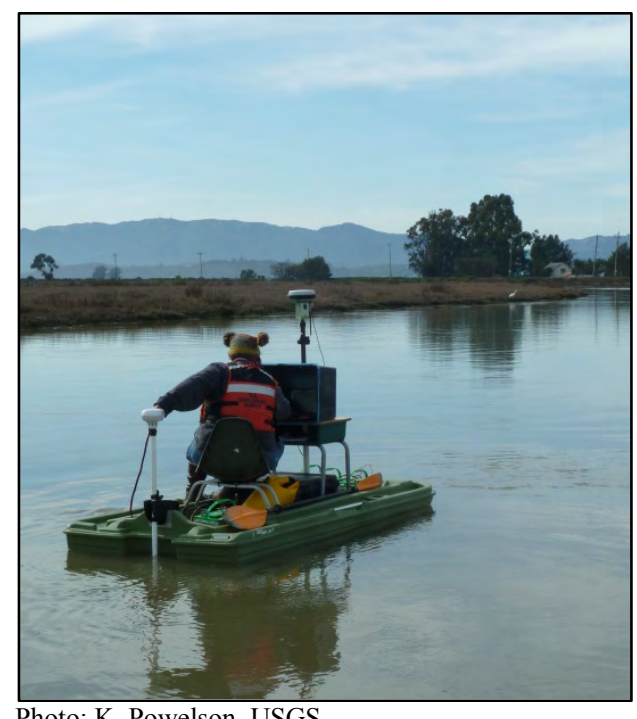

Photo: K. Powelson. USGS

Figure 7. U.S. Geological Survey technician conducting bathymetric surveys at San Pablo Bay National Wildlife Refuge, northern California. Photograph by Katherine Powelson, U.S. Geological Survey, 2012. 


\subsection{Bathymetry Modeling}

We synthesized the bathymetry data to create a DEM of the mudflat and subtidal regions at Mad River, San Pablo, Bolinas, Morro, Pt. Mugu, and Newport using ArcGIS ${ }^{\mathrm{TM}}$ 10.2.1 Spatial Analyst (Environmental Systems Research Institute, Incorporated, 2013, Redlands, California) with exponential ordinary kriging methods $(5 \times 5 \mathrm{~m}$-cell size $)$. We removed parts of the bathymetry data that overlapped with elevation surveys conducted on the marsh. In this report, we present elevation data as local orthometric heights (NAVD 88).

\subsection{Paleoenvironmental Coring}

\section{Stratigraphic Coring}

From 2012 to 2014, we collected a total of 63 stratigraphic cores from three marshes in Humboldt Bay (Eureka Marsh, Jacoby Slough, and Mad River Slough), and from marshes in Bolinas Lagoon, Morro Bay, Mugu Lagoon, Upper Newport Bay, and Tijuana Estuary (fig. 8).

We used a 1-m-long Russian peat borer for all sediment recovery, with multiple drives to capture sediment deeper than $1 \mathrm{~m}$. Core samples typically spanned surface peat with active growing marsh vegetation down to impenetrable sands, marine shell-rich intertidal mud, or bedrock. We wrapped samples in plastic wrap, supported by an outer layer of aluminum foil in the field, and transported them to a laboratory at the University of California, Los Angeles, in specialized core boxes for cold room storage at $4{ }^{\circ} \mathrm{C}$.

We attempted to collect two replicate cores to characterize sediments from low-, middle-, and high-elevation zones, for a total of six cores at each site. We estimated marsh elevation zones in the field using observations of species composition and digital elevation maps, and by estimating the distance from open water or channels. We took duplicate cores adjacent to each pair of SETs at Mad River Slough in Humboldt Bay, Bolinas, Pt. Mugu, Morro Bay, Seal Beach, Newport, and Tijuana.

The cores we collected ranged in length from 17 to $600 \mathrm{~cm}$ and averaged $170 \mathrm{~cm}$. We processed 38 cores to measure apparent accretion rate using one or more radiocarbon $\left({ }^{14} \mathrm{C}\right)$ dates, and 16 others were maintained as archival material. Nine cores were collected too recently to submit for any kind of analysis. 

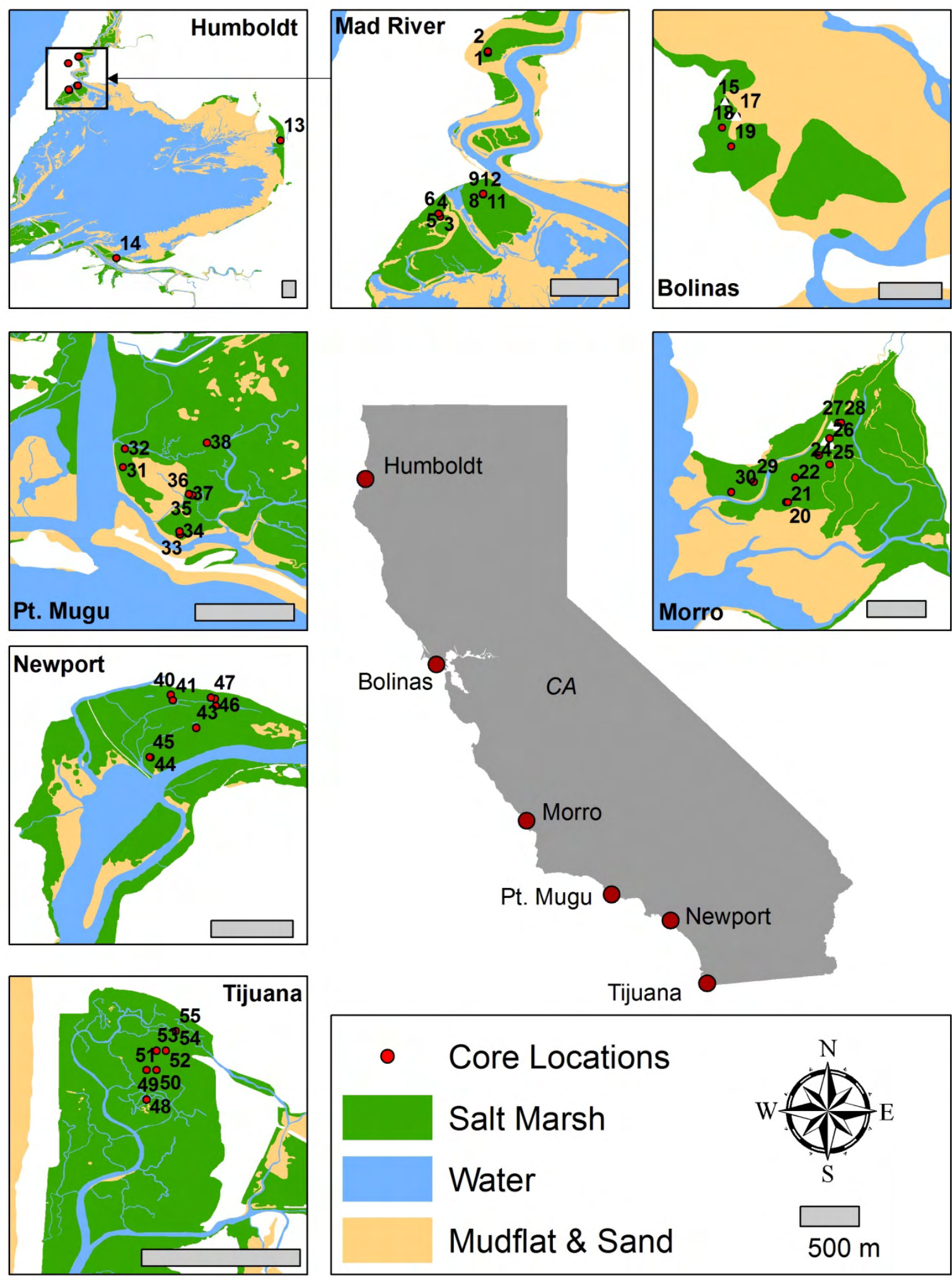

Figure 8. Location of six California coastal marsh sites where soil cores were collected. Detailed study sites show coring locations of the 55 cores analyzed for paleoenvironmental data (see table 8). 


\section{Chronology and Accretion Rates}

We sampled macrofossil samples (plant fragments and marine shells) from basal sediments in 38 cores for radiocarbon dating. We also sampled horizons of particular interest, such as abrupt color or texture transitions. As often as possible, we avoided dating plant macrofossils to minimize the error associated with dating intrusive below-ground material such as roots. However, when no other organic samples were identified in horizons of interest, we dated plant macrofossils. Plant macrofossils were limited to those deposited horizontally in the sample, with identifiable stomata, or identifiable as aboveground matter. In cores taken from Tijuana and Bodega Bay, we also used bulk sediment samples of $0.1 \mathrm{~g}$ because of the lack of plant or shell material.

We conducted ${ }^{14} \mathrm{C}$ dating at the University of California, Irvine, Keck Carbon Cycle Accelerator Mass Spectrometry Laboratory (KCCAMS/UCI) using an accelerator mass spectrometer (AMS). Plant macrofossil preparation included drying, weighing, and treatment with an acid-alkali-acid wash, followed by combustion of the sample in a sealed tube with cuprous oxide and silver wire and graphitization. We prepared marine shell samples by drying, weighing, and leaching surficial carbonates with dilute hydrochloric acid, and hydrolyzing samples using phosphoric acid, before performing graphitization according to the small-sample method used in the KCCAMS/UCI facilities (Santos and others, 2007).

We calibrated AMS dates using INTCAL13 for organic plant macrofossils and MARINE13 for marine shells and bulk soil samples (Reimer and others, 2013). We report the median age and minimum and maximum ages for the two standard deviations $(2 \sigma)$ probability distribution. Some samples were enriched with modern carbon from atmospheric fallout of nuclear weapons testing peaking in the 1960s. For these "post-bomb" dates, we used the same calibration method using the NH2 post-bomb curve instead of INTCAL13 or MARINE13.

We estimated long-term accretion as the amount of vertical accumulation divided by the time spanning the deepest ${ }^{14} \mathrm{C}$ age control (non-enriched with modern carbon) and the core collection date.

\section{Radiocesium Analysis}

To establish a consistent datum for comparing accretion across multiple cores, we analyzed several exploratory samples for radiocesium $\left({ }^{137} \mathrm{Cs}\right)$ activity as previously done for the San Francisco Bay Area in Callaway and others (2012). Peaks in atmospheric ${ }^{137} \mathrm{Cs}$ fallout are a byproduct of a peak in nuclear testing during 1963. We analyzed samples by BETA counting to calculate ${ }^{137} \mathrm{Cs}$ activity with 27 samples from five cores submitted to the Paleoecological Environmental Assessment and Research Laboratory (P.E.A.R.L.) at Queen's University in Kingston, Ontario, and 27 samples from three cores submitted to Core Scientific International in Winnipeg, Manitoba. Samples from P.E.A.R.L. were received in the units becquerels (bq) per $\mathrm{kg}$, but were converted to disintegrations per minute (dpm per $\mathrm{g}$ ), where $1,000 \mathrm{bq} / \mathrm{kg}=60 \mathrm{dpm} / \mathrm{g}$ ). For samples that had identifiable ${ }^{137} \mathrm{Cs}$ peaks, we calculated accretion rates by assuming that the bottom of the sample containing the peak represents 1963 . 


\section{Physical Sediment Characteristics}

We photographed cores and documented any visible changes in color or sediment type or content with the aid of the Munsell Sediment Color Chart. We measured the magnetic susceptibility of sediment characteristics using Bartington MS3 magnetic susceptibility equipment and software (Thompson and Battarbee, 1975).

For a subset of cores, we used color analysis, and changes in soil and organic matter and bulk density to identify the depth of modern marsh peat. After subsectioning cores at 1-cm intervals using a sharp, clean knife, we extracted a $1-\mathrm{cm}^{3}$ sample and weighed it before and after the following: dehydration at $105^{\circ} \mathrm{C}$ to a constant weight, ignition in a muffle furnace at $550{ }^{\circ} \mathrm{C}$ for $4 \mathrm{~h}$, and ignition in a muffle furnace at $950^{\circ} \mathrm{C}$ for $1 \mathrm{~h}$. We used the mass loss in these steps to calculate bulk density, organic matter content, and carbonate content, respectively (Heiri and others, 2001).

\subsection{Monitoring Marsh Elevations}

We installed deep rod Surface Elevation Tables (SETs) to quantify the relative contributions of surface and subsurface processes to present-day elevation change (that is, root growth, decomposition, compaction, water flux), shallow subsidence (accretion-elevation), and shallow subsidence between shallow (root zone) and deeper (to $>10 \mathrm{~m}$ ) parts of the soil profile (figs. 9 and 10). We installed four SETs at each marsh site, following methods described by Cahoon and others (2002) and Webb and others (2013). We established two SETs in low marsh and two in high marsh at each site after visual assessment of vegetation composition and distance from tidal source. We deployed each SET with three feldspar marker horizon plots. When the SET instrument is attached to the installed benchmark, the SET provides a constant reference plane in space from which the distance to the sediment surface can be measured by means of pins lowered to the sediment surface. SET measurements are taken by reading the heights of nine pins lowered to the sediment surface using the SET instrumentation at four directions, which are 90 degrees from each other. Repeated measurements of elevation can be made with high precision because the orientation of the table in space remains fixed for each sampling. We are conducting ongoing measurements every 3 months at all sites.

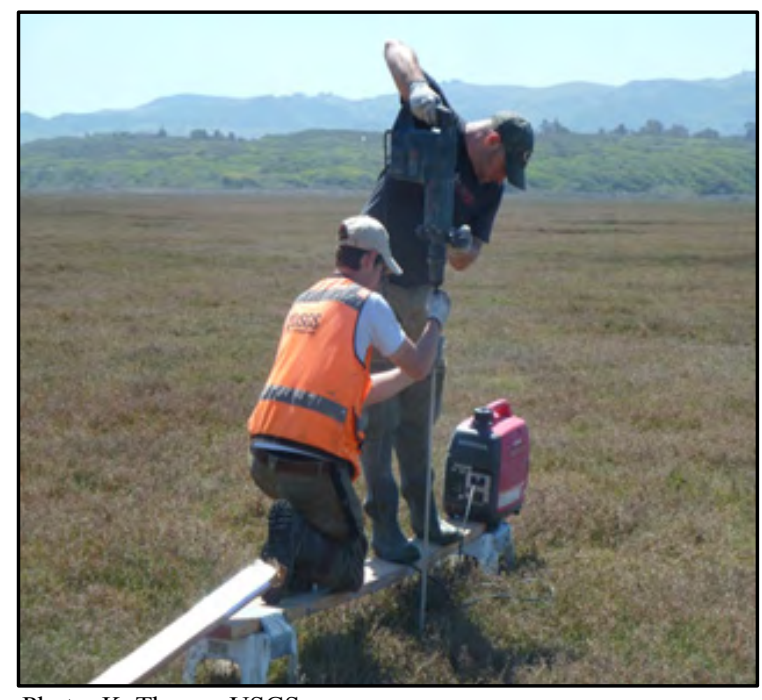

Photo: K. Thorne. USGS

Figure 9. U.S. Geological Survey technicians from Patuxent Wildlife Research Center and Western Ecological Research Center installing a Surface Elevation Table at Morro Bay, central California. 


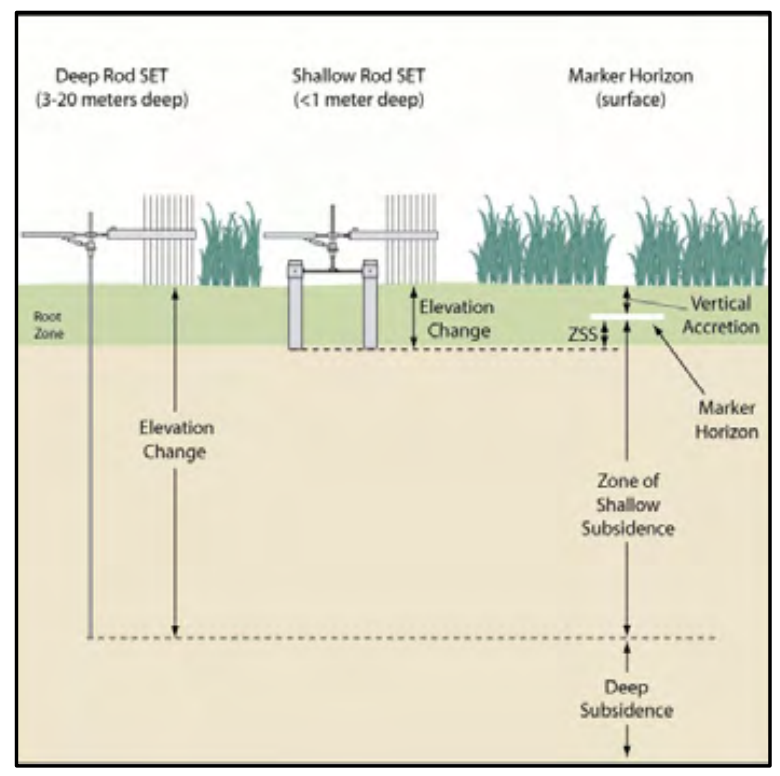

Figure 10. Conceptual diagram showing how the soil profile is measured by Surface Elevation Table and marker horizon techniques to assess different processes in marsh soils (from Cahoon and others, 2002).

\subsection{Future Storm Impacts with Sea-Level Rise}

The Coastal Storm Modeling System (CoSMoS) was developed as a general model for assessing the effects of climate change on coasts, including the influence of SLR and storms (Barnard and others, 2014). CoSMoS applies a predominantly deterministic framework to cover large geographic scales (hundreds to thousands of kilometers) but at fine-scale local resolution (approximately tens of meters) to provide coastal managers with climate-related hazard information that can be used to increase public safety, mitigate physical and ecological damage, and more effectively manage and allocate resources (Barnard and others, 2009).

We downscaled a community mesoscale model, the Weather Research and Forecasting Model 3.2 (WRF; Skamarock and others, 2008). Baseline and future (2041-2060) simulations applied dynamical downscaling of a publicly available, coarse-resolution (32-km) archive of weather and climate variations over North America from 1981 to 2000. The coarse-resolution archive contained data from the National Center for Environmental Prediction 3-hourly North American Regional Reanalysis (NARR), used to provide lateral boundary conditions of the outermost domain and ocean surface boundary conditions. 
We applied the representative concentration pathway RCP8.5 "business as usual" emissions scenario (Moss and others, 2008) from IPCC -Fifth Assessment Report (AR5) and monthly simulations from the National Center for Atmospheric Research Community Climate System Model v.4 (CCSM4; Gent and others, 2011). All variables were included in the climate-change signal (that is, threedimensional atmospheric variables - temperature, relative humidity, zonal and meridional winds, and geopotential height; and two-dimensional surface variables - temperature, relative humidity, winds, and pressure). We perturbed baseline NARR reanalysis data monthly with CCSM4-generated signals and constructed regional boundary conditions imposed on the outermost domain. We compared the simulation with baseline data to assess the impact of downscaled CCSM4 signals. Carbon dioxide $\left(\mathrm{CO}_{2}\right)$ levels were increased in the WRF to match $\mathrm{CO}_{2}$-equivalent radiative forcing in the RCP8.5 scenario. A global wave model (WaveWatch3) drove nested wave and hydrodynamic models (SWAN, Delft3D Flow, XBeach) to make parcel-scale predictions of coastal inundation, flooding, and beach erosion.

We forced CoSMoS with a suite of General Circulation Models (GCMs) driven by the latest $\mathrm{RCP}$ radiative forcing scenarios at Pt. Mugu, Newport, and Tijuana. We overlayed the resulting CoSMoS layers onto the DEM of each site. These models provide local information for future wave impacts and inundation, including frequency and depth of inundation under a range of SLR and storm scenarios covering daily to 100 -year recurrence intervals.

\subsection{Tidal Marsh Ecosystem Response Modeling}

We used WARMER, a one-dimensional cohort model of wetland accretion (Swanson and others, 2014), which is based on Callaway and others (1996), to examine the effects of three SLR projections on future habitat composition at each study site except San Pablo. Each cohort in the model represents the total organic and inorganic matter added to the soil column each year. WARMER calculates annual elevation changes relative to mean sea level (MSL) based on projected changes in relative sea level, subsidence, inorganic sediment accumulation, aboveground and belowground organic matter inputs, soil compaction, and organic matter decomposition for a representative marsh area (fig. 11, table 3). Cohort density, a function of soil mineral, organic, and water content, is calculated at each time step to account for the decay of organic material and compaction of the soil column. The change in relative elevation is then calculated as the difference between the change in modeled sea level and the change in height of the soil column, which was estimated as the sum of the volume of all cohorts. In the model, the elevation of the marsh surface, $E$, at time $t$ relative to local MSL is estimated as

$$
E(t)=E(0)-S L R(t)+\sum_{i=0}^{t} V_{i}(t)
$$

where $\quad E(0) \quad$ is the initial elevation relative to MSL,

$S L R(t) \quad$ is the sea-level at time $t$ relative to the initial sea level, and

$V_{i}(t) \quad$ is the volume per unit area, or height, at time $t$, of the cohort formed during year $i$.

We used WARMER to model decadal-scale changes in tidal wetland elevation at each site and summarized these data as changes in the spatial extent of the tidal marsh zones defined previously. 


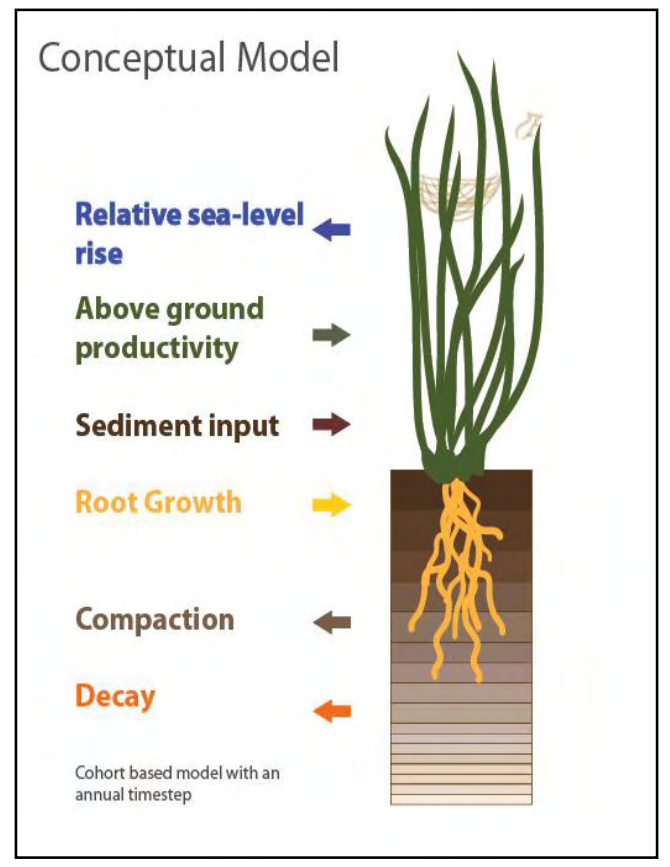

Figure 11. WARMER one-dimensional cohort conceptual model of wetland accretion showing input variables for the modeling approach (Swanson and others, 2014). 
Table 3. WARMER model parameters and soil core characteristics used for model calibration across California study sites.

[Sediment accumulation rate is reported at the elevation of mean sea level (MSL). cm, centimeter; $\mathrm{g} / \mathrm{cm}^{3}$, gram per cubic centimeter; $\left[\left(\mathrm{g} / \mathrm{cm}^{2}\right) / \mathrm{yr}\right]$, gram per square centimeter per year; $\mathrm{mm} / \mathrm{yr}$, millimeter per year]

\begin{tabular}{|c|c|c|c|c|c|c|}
\hline Model parameter & Mad River & Bolinas & Morro & Pt. Mugu & Newport & Tijuana \\
\hline${ }^{1}$ Sediment accumulation rate $\left[\left(\mathrm{g} / \mathrm{cm}^{2}\right) / \mathrm{yr}\right]$ & 0.392 & 1.05 & 0.15 & 1.44 & 0.253 & 0.193 \\
\hline Elevation of peak biomass (cm, MSL) & 110 & 91 & 93 & 87.9 & 92 & 73.2 \\
\hline $\begin{array}{l}\text { Minimum elevation of vegetation (cm, } \\
\text { MSL) }\end{array}$ & 40 & 21 & 16.2 & 30.9 & 2 & 11.2 \\
\hline $\begin{array}{l}{ }^{1} \text { Maximum aboveground organic } \\
\text { accumulation }\left[\left(\mathrm{g} / \mathrm{cm}^{2}\right) / \mathrm{yr}\right]\end{array}$ & 0.0629 & 0.0783 & 0.0550 & 0.1656 & 0.0338 & 0.0502 \\
\hline Root-to-shoot ratio & 0.458 & 0.458 & 0.458 & 0.458 & 0.458 & 0.458 \\
\hline${ }^{1}$ Porosity at the surface (percent) & 89 & 79 & 90 & 60 & 87 & 87 \\
\hline${ }^{1}$ Porosity at depth (percent) & 55 & 59 & 75 & 41 & 38 & 74 \\
\hline${ }^{1}$ Refractory carbon (percent) & 25.8 & 26 & 16.7 & 5.9 & 8.9 & 7.00 \\
\hline Maximum astronomical tide (cm, MSL) & 257 & 142 & 133 & 118 & 157 & 136.2 \\
\hline Historical sea-level rise ( $\mathrm{mm} / \mathrm{yr})$ & 4.7 & 2.10 & 0.79 & 2.33 & 2.22 & 2.06 \\
\hline Organic matter density $\left(\mathrm{g} / \mathrm{cm}^{3}\right)$ & 1.14 & 1.14 & 1.14 & 1.14 & 1.14 & 1.14 \\
\hline Mineral density $\left(\mathrm{g} / \mathrm{cm}^{3}\right)$ & 2.61 & 2.61 & 2.61 & 2.61 & 2.61 & 2.61 \\
\hline
\end{tabular}

${ }^{1}$ Parameter values were calibrated to soil core characteristics.

Model Inputs

Sea-Level Rise Scenario

In WARMER, we used the National Research Council (2012) forecast for the Pacific coast that projects low, mid, and high SLR scenarios of 44, 93, and $166 \mathrm{~cm}$ by 2110 , respectively. We used NRC average annual SLR curve as the input function for the WARMER model. In the modeling exercises, we assumed that tide range remained constant through time, with only the position of MSL relative to land changing annually. 
Inorganic Matter

The annual sediment accretion rate is a function of inundation frequency and the mineral accumulation rates measured from ${ }^{137} \mathrm{Cs}$ dating of soil cores sampled across each site. For each site, we developed a continuous model of water level from the major harmonic constituents of a nearby NOAA tide gauge. This allowed a more accurate characterization of the full tidal regime, as our water loggers were located above MLLW. Following Swanson and others (2014), we assumed that inundation frequency was directly related to sediment mass accumulation; this simplifying assumption does not account for the potential feedback between biomass and sediment deposition and holds suspended sediment concentration and settling velocity constant. Sediment accretion, $M s$, at a given elevation, $z$, is equal to

$$
(z)=S *(z)
$$

where $f(z) \quad$ is dimensionless inundation frequency as a function of elevation $(z)$, and $S \quad$ is the annual sediment accumulation rate, in $\left[\left(\mathrm{g} / \mathrm{cm}^{2}\right) / \mathrm{yr}\right]$.

We calibrated the amplitude of the logistic function to the sediment accumulation rates from the soil cores (fig. 8), which were sampled across an elevation gradient at each study site. This method allowed us to estimate an annual accumulation rate $[(\mathrm{g} / \mathrm{cm}) / \mathrm{yr}]$ for each of our study sites (fig. 12).

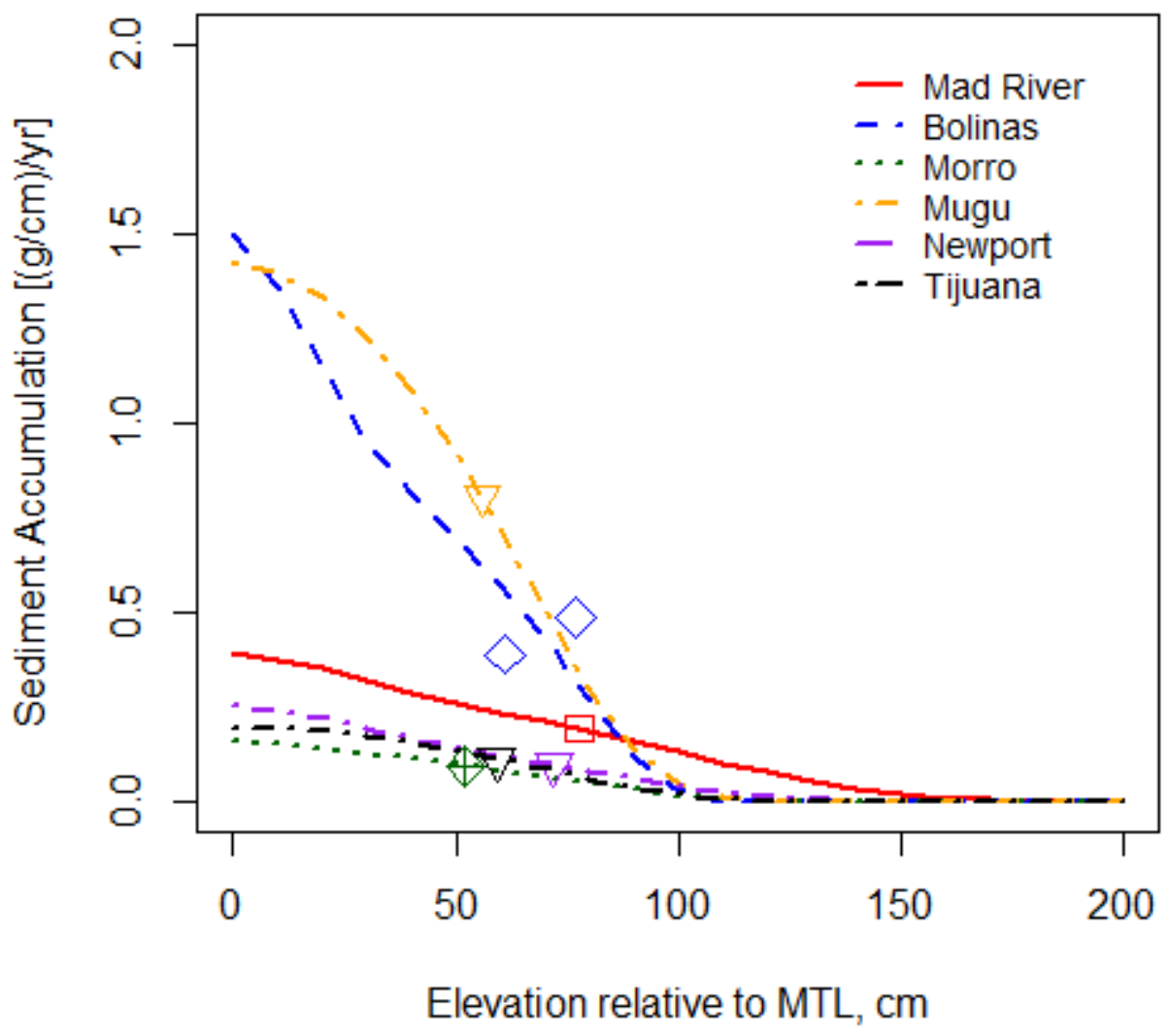

Figure 12. Annual sediment accumulation function with elevation curves (lines) and measured accumulation rates (points) at six study sites in California. 


\section{Organic Matter}

We used a unimodal functional shape to describe the relationship between elevation and organic matter inputs to new soils, based on Atlantic coast work on Atlantic cordgrass (Spartina alterniflora) (Morris and others, 2002), and developed site-specific, asymmetric elevation-productivity relationships. We used Bezier curves to draw a unimodal parabola, anchored on the low elevation by the minimum elevation of vegetation from our surveys and at the high elevation by the maximum observed water level from a nearby NOAA tide gauge. We determined the elevation of peak productivity by analyzing the Normalized Difference Vegetation Index (NDVI; [(NIR - Red)/(NIR + Red)]) from 2011 National Agriculture Imagery Program imagery (4 spectral bands, 1-m resolution; Tucker, 1979) and our interpolated DEM. We then calibrated the amplitude of the unimodal function for the organic matter input rates (determined from sediment accumulation rates and the percent organic matter in the surface layer of the core) obtained from sediment cores across an elevation range at each site (fig. 13). To partition organic matter inputs between aboveground and belowground fractions, we used a constant root-to-shoot ratio for organic matter production, determined from preliminary experimental data on flooding impacts to Pacific swampfire (Sarcocornia pacifica) growth in the San Francisco Bay estuary (Janousek and others, 2016). The mass of organic material generated belowground each year was distributed exponentially with depth, and the coefficient of exponential decay, $\boldsymbol{k d i s t}$, was set equal to 1.0 (Deverel and others, 2008).

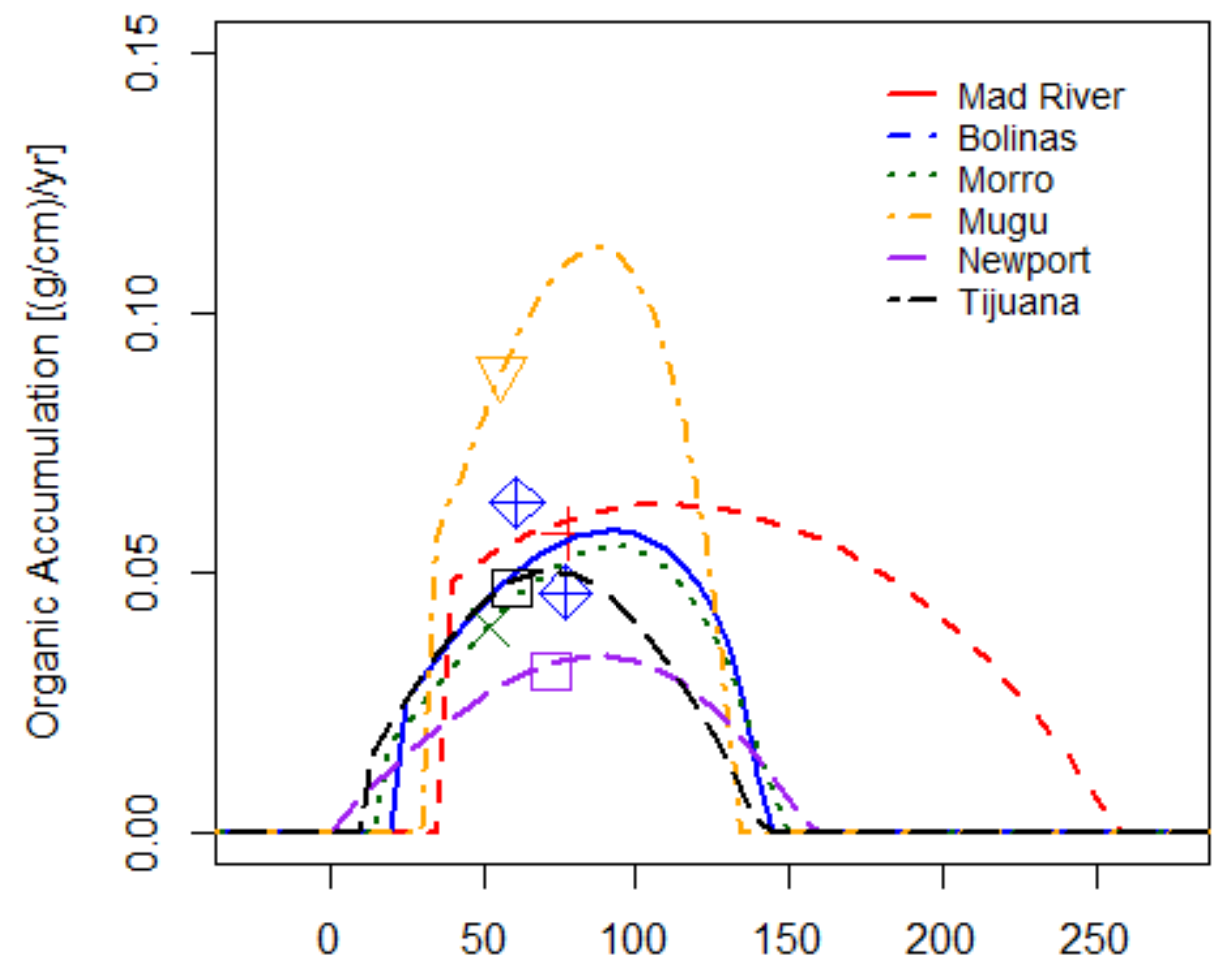

Elevation relative to $\mathrm{MTL}, \mathrm{cm}$

Figure 13. Organic matter accumulation function with elevation (lines) and measured accumulation rates (points) at six study sites in California. Site-specific elevations of low marsh-mudflat boundary, maximum observed water level, and peak aboveground biomass were used to draw the curves. The amplitude of each curve was calibrated to measured accumulation rates from sediment cores. 
Compaction and Decomposition

Compaction and decomposition functions in the WARMER model followed Callaway and others (1996). We determined sediment compaction using the difference in measured porosity between the top $5 \mathrm{~cm}$ and the bottom $5 \mathrm{~cm}$ of each sediment core. We estimated the rate of decrease, $r$, in porosity of a given cohort as a function of the density of all material above that cohort:

$$
r=1-\frac{p_{b}}{k_{1}-p_{b}}
$$

where $\quad p_{b}$ is the density of the material above a cohort and $k_{I}$ was a calibration constant.

Following Swanson and others (2014), we modeled decomposition as a three-stage process where the youngest organic material (less than one year old) decomposed at the fastest rate, organic matter one to two years old decayed at a moderate rate, and organic matter greater than two years old decayed at the slowest rate. Decomposition also decreased exponentially with depth. We determined the percentage of refractory (insoluble) organic material from the organic content measured in the sediment cores. We used constants to parameterize the compaction and decomposition functions from Deverel and others (2008). Model parameters are provided in a table for each site except San Pablo (table 3; appendix tables A4 and C4-G4). 


\section{Section 5-Project Results}

\subsection{Tidal Wetland Elevations}

Tidal marsh DEMs spanned about $2 \mathrm{~m}$ of vertical relief at most of the study sites, with most elevation data points occurring within a 1-m band centered near local MHHW (fig. 14; table 4). Individual sites varied significantly in median elevation relative to MHHW, with the highest median elevation at Pt. Mugu and Mad River and the lowest median elevation at San Pablo (figs. 14-15).

Overall topographic range was large at most sites, indicating that a range of tidal marsh vegetation zones was present (fig. 16). Mad River, however, had a relatively more constrained elevation profile; it was mostly high tidal marsh. We compared marsh topographic profiles among the seven sites with pair-wise Kolmogorov-Smirnov tests. All sites had significantly different topographic profiles (all $P<0.00001)$.

We used flooding extent to delineate tidal marsh habitats. Mad River Slough was comprised mostly of high and middle tidal marsh vegetation zones (figs. 17-18). San Pablo was comprised mostly of middle marsh, with patches of high marsh occurring throughout the site and a fringe of low marsh present immediately adjacent to San Pablo Bay. Bolinas, Morro, Pt. Mugu and Newport each supported a range of habitats from transitional marsh and upland to low marsh. Tijuana was comprised mostly of middle-elevation marsh, with a narrow fringe of high marsh at the eastern end of the site. High and transitional marsh habitats were most abundant at Bolinas and Pt. Mugu. 
Table 4. Sample size, mean elevation and elevation range of Real Time Kinetic Global Positioning System elevation points collected at all study sites in the California Coastal Ecosystem Response to Climate Change network.

[Sites are ordered from north to south. Elevations are in meters above North American Vertical Datum of 1988]

\begin{tabular}{lcccccc}
\hline Site & $\begin{array}{c}\text { Surveyed } \\
\text { area } \\
\text { (hectares) }\end{array}$ & $\begin{array}{c}\text { Elevation data } \\
\text { points } \\
\text { (number) }\end{array}$ & $\begin{array}{c}\text { Mean } \\
\text { elevation } \\
\text { (meters) }\end{array}$ & $\begin{array}{c}\text { Maximum } \\
\text { elevation } \\
\text { (meters) }\end{array}$ & $\begin{array}{c}\text { Minimum } \\
\text { elevation } \\
\text { (meters) }\end{array}$ & $\begin{array}{c}\text { Elevation } \\
\text { range } \\
\text { (meters) }\end{array}$ \\
\hline Mad River & 38.3 & 852 & 2.06 & 2.43 & 1.43 & 1.00 \\
San Pablo & 136.3 & 315 & 1.78 & 2.05 & 0.57 & 1.48 \\
Bolinas & 83.7 & 1,622 & 1.62 & 2.63 & 1.20 & 1.43 \\
Morro & 150.3 & 2,575 & 1.63 & 2.82 & 1.03 & 1.79 \\
Pt. Mugu & 109 & 1,720 & 1.74 & 2.75 & 1.13 & 1.62 \\
Newport & 59.8 & 1,037 & 1.55 & 2.81 & 0.81 & 2.00 \\
Tijuana & 61.7 & 989 & 1.56 & 2.58 & 1.17 & 1.41 \\
\hline
\end{tabular}




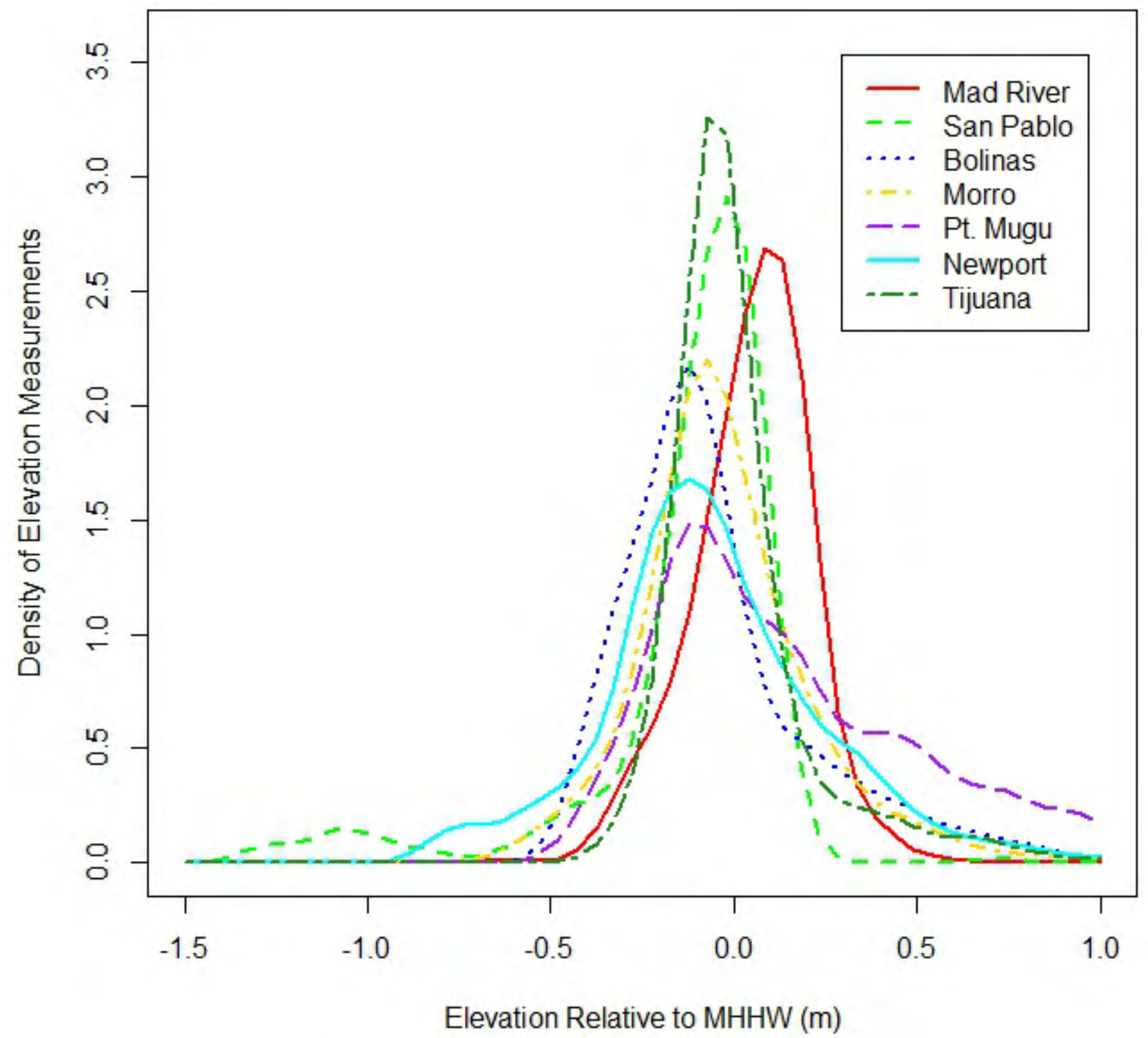

Figure 14. Density of marsh surface elevation measurements relative to mean higher high water (MHHW) across the seven study sites, California. 


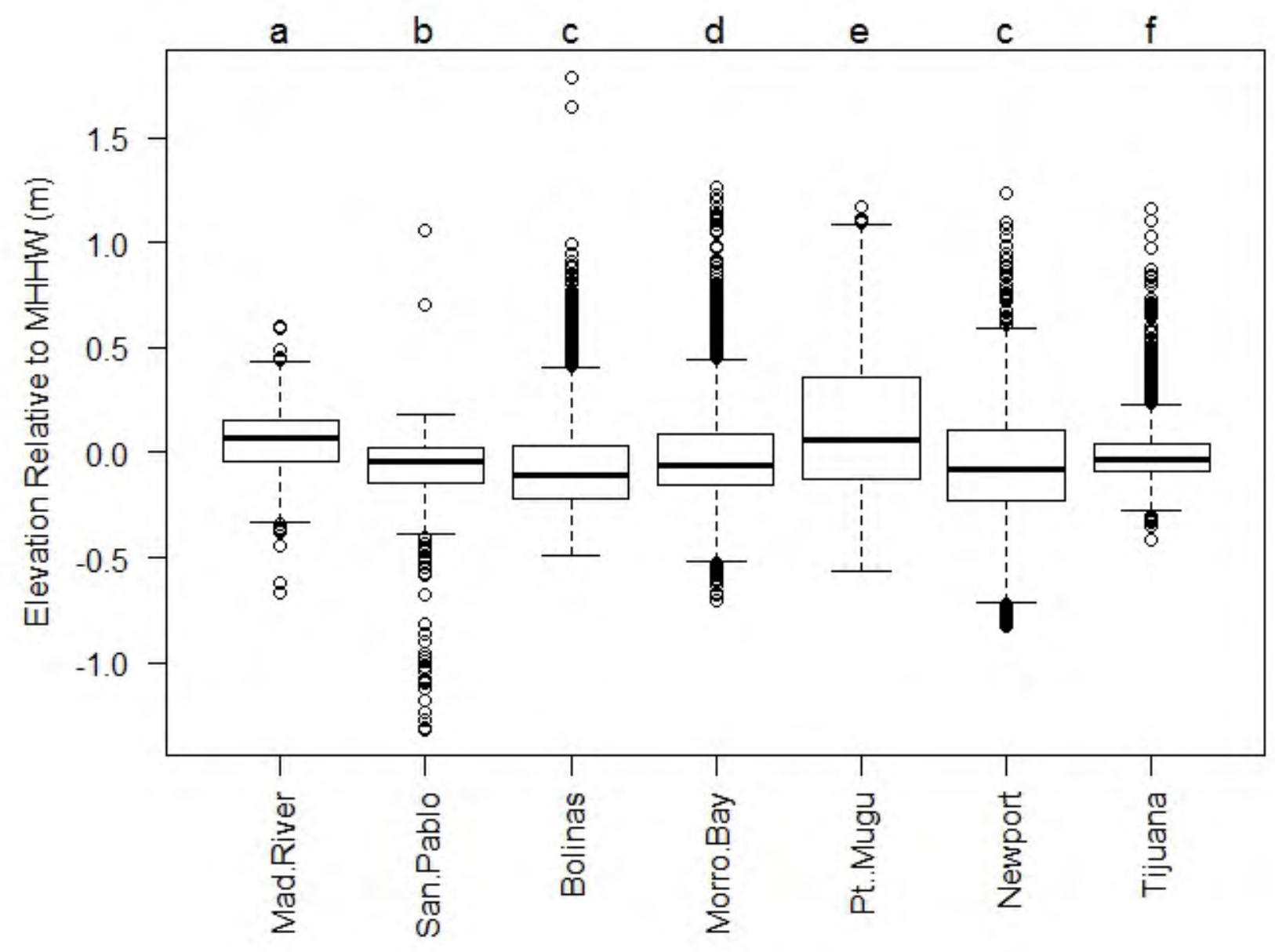

Figure 15. Boxplot showing distribution of marsh surface elevation data points across all seven California study sites (in meters [m] relative to mean higher high water [MHHW]). Black horizontal indicate median elevation, boxes indicate the 25- and 75-percent distribution quantiles, upper and lower whiskers encompass points no greater than 1.5 times the length of the box, and circles indicate outliers. Letters above the plot represent significant differences in mean elevation. 


\section{Elevation Distribution Comparison}

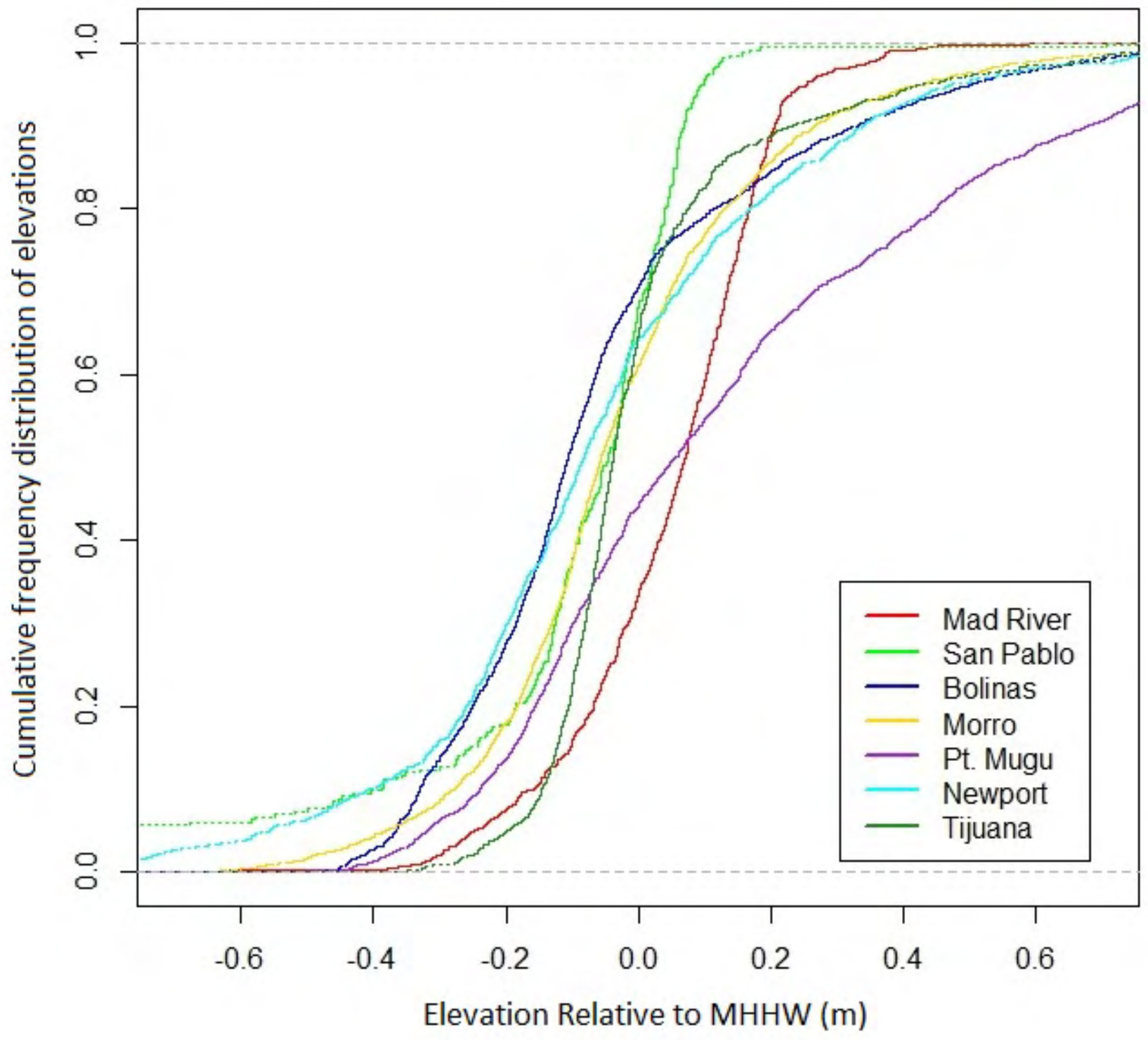

Figure 16. Cumulative frequency distribution of marsh elevation points relative to mean higher high water (MHHW, in meters [m]) across seven study sites, California. More steeply sloping curves indicate sites with more pronounced marsh platforms. Less steeply sloping curves indicate marshes with more gradual changes in elevation. 

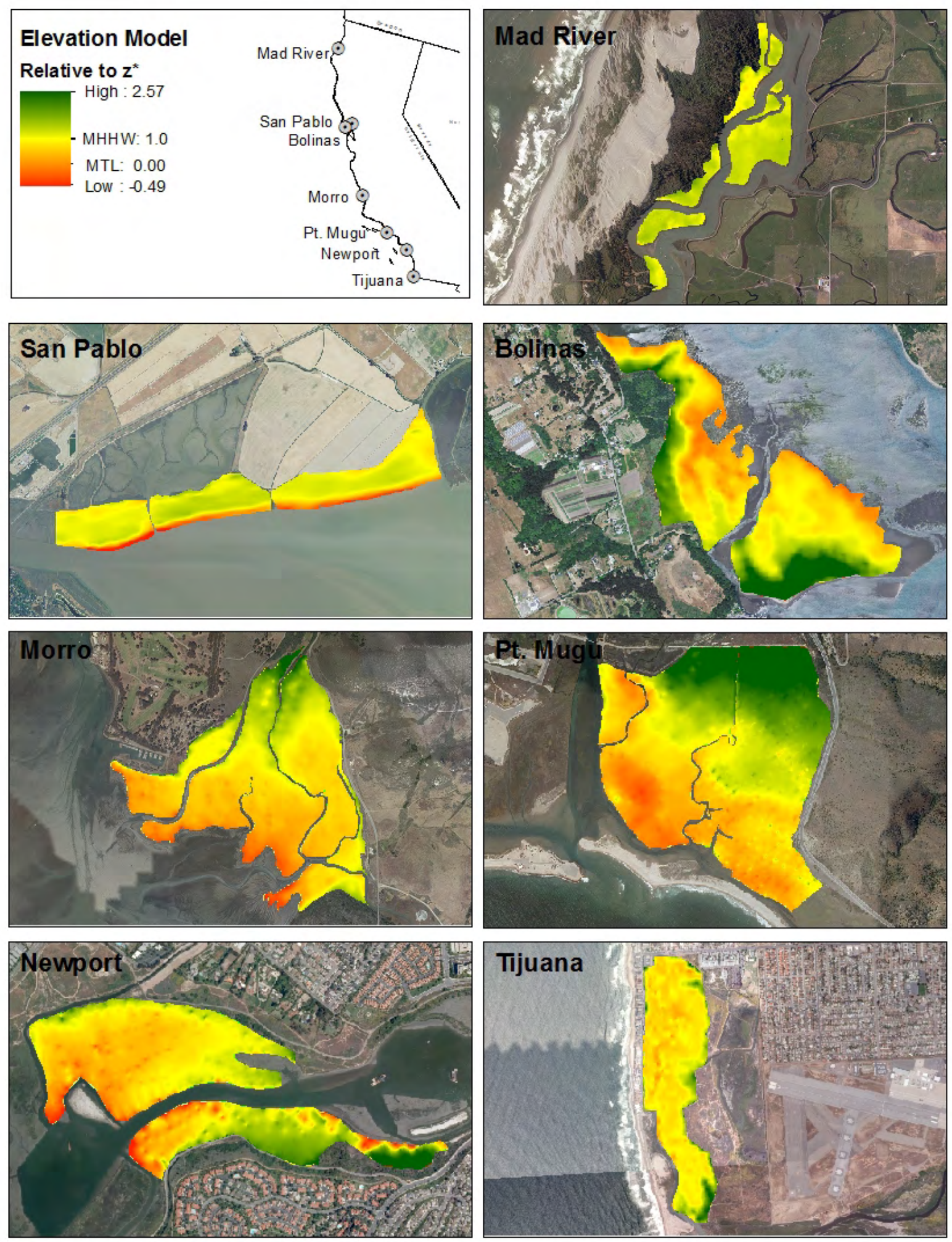

Figure 17. Tidal marsh digital elevation models across the seven study sites in the Coastal Ecosystem Response to Climate Change network, California. Elevations are represented by $z^{*}$ values, where elevation is standardized to local tidal range. 

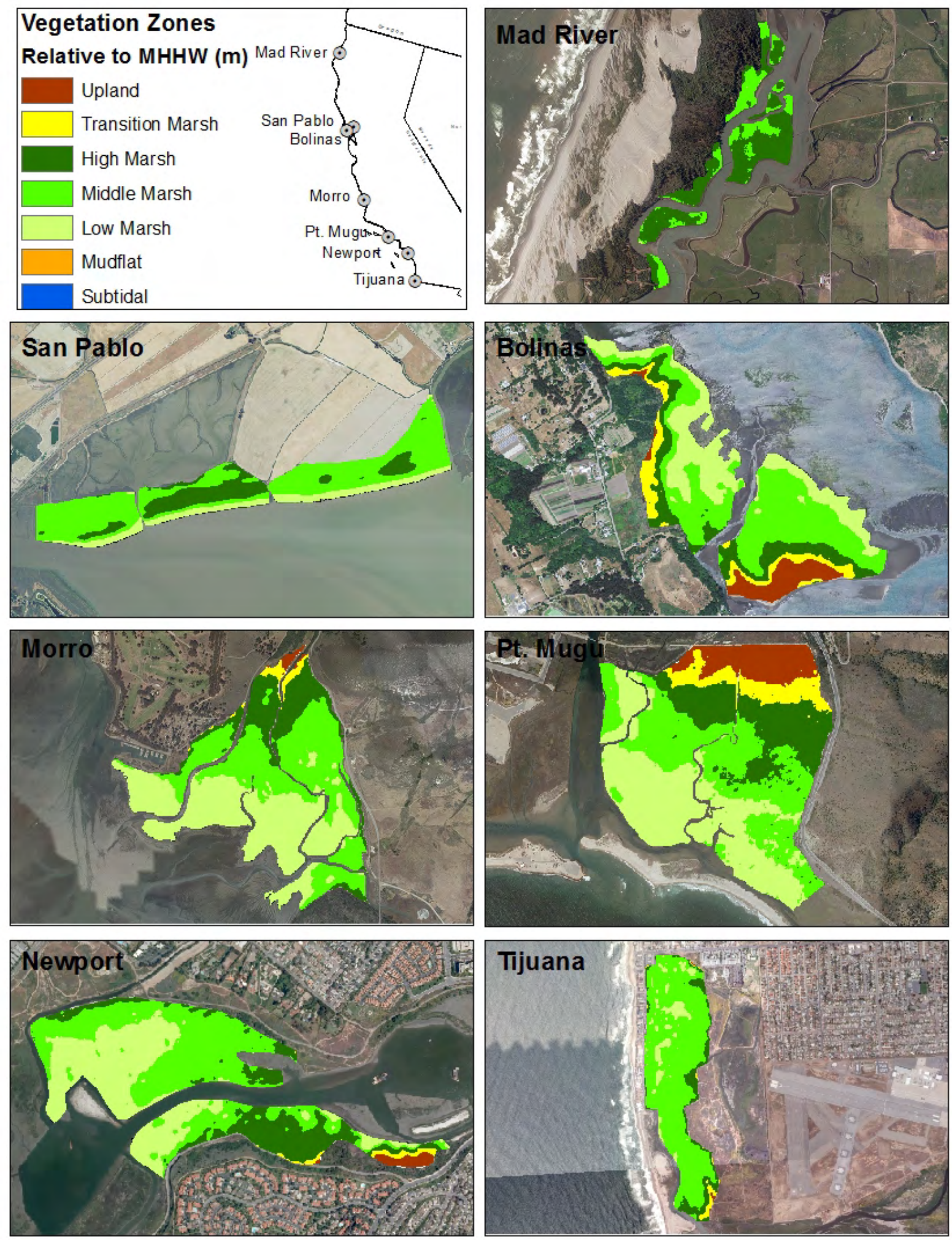

Figure 18. Distribution of tidal marsh vegetation zones across the seven study sites in the Coastal Ecosystem Response to Climate Change network, California. Vegetation zones were defined a priori by the lower extent of surveyed vegetation and long-term tidal inundation data. 


\subsection{Vegetation}

More than 2,000 intertidal plots were sampled for plant cover, frequency of occurrence, and species richness across the six study sites (table 5). Approximately 57 vascular plant species were found in the study, including grasses, rushes, forbs, and sedges. Vegetated marsh ranged in elevation from local mean tide level (MTL) to the marsh-upland transition zone (upland plots, defined as areas estimated to flood less than 1 time per year on average, were not considered for further analysis).

Pacific swampfire (Sarcocornia pacifica) was the dominant species across the marshes in this study, occurring in at least 64 percent of all plots at every study site (fig. 19). At the three sites in central and northern California, it occurred in more than 90 percent of all vegetation plots. Subdominant marsh species included saltgrass (Distichlis spicata), marsh jaumea (Jaumea carnosa), California cordgrass (Spartina foliosa), saltwort (Batis maritima) and alkali-heath (Frankenia salina). Subdominants differed in their frequency of occurrence by site. For example, Spartina foliosa was a common low-elevation species at two sites in southern California (Tijuana and Newport) and also occurred at Bolinas, but was absent from Morro and Mad River and relatively uncommon at Pt. Mugu. Distichlis spicata was very common at Mad River (present in 89 percent of plots), and relatively common at Bolinas (47 percent), but less common at all other sites ( $\leq 23$ percent). Jaumea carnosa was relatively common at all sites (ranging from 22 to 73 percent frequency). Frankenia salina was relatively common at Pt. Mugu and Tijuana (40 and 44 percent, respectively); moderately common at Newport, Morro, and Bolinas (13, 25, 23 percent, respectively); and absent from Mad River.

Total vascular plant richness was somewhat higher at Mad River in Humboldt Bay (24 species across the site) than at the other California sites we surveyed (16-21 species each), despite having the smallest sample size (table 5). At the plot level, average $( \pm \mathrm{SD})$ plant richness also was higher at Mad River $(5.1 \pm 2.4)$ than at the other California sites (fig. 20).

Vascular plant species tended to exhibit vertical zonation; however, the degree of vertical separation among co-occurring species differed by site (appendix tables A2, C2-G2). For instance, at Newport, species tended to occupy different vertical niches: Spartina foliosa was present in low and middle marsh zones; Jaumea, Sarcocornia, and Batis tended to occupy the middle marsh zone; and Frankenia generally occurred in high marsh zone (appendix figs. A5, C5-G5). In contrast, vertical zonation of common species was much less pronounced at Mad River, where most taxa tended to occupy upper middle to high marsh habitat and had broadly overlapping distributions (appendix figs. A5, C5-G5). Across the study, many common species occurred across a broad range of elevations.

Depending on the degree of vertical zonation among species and the degree of overall dominance by particular species at a site, individual marsh zones more or less differed in plant species abundance and composition within a site (appendix tables A1, C1-G1). At some sites (for example, Morro), Sarcocornia pacifica had high cover in all four tidal marsh zones, so zones tended to differ mainly in the composition of subdominant species. At Newport however, elevation zones had more distinct plant assemblages: Sarcocornia pacifica had the greatest cover in high marsh, Jaumea carnosa was the dominant species in middle marsh, and Spartina foliosa was dominant in low marsh. 
The vegetation data indicated some notable patterns with respect to species endemism and the prevalence of non-native taxa (appendix tables A1,C1-G1). Several species were present at only a single site, including the local endemic Castilleja ambigua ssp. Humboldtiensis, grouped with Chloropyron maritimum ssp. palustre during the field census) present at Mad River. We sampled a threatened species, Pt. Reyes tidal marsh bird's-beak (Choropyron maritimum ssp. palustre), at Mad River and Bolinas. About 10 non-native species occurred in the dataset, including Atriplex prostrata, Cakile edentula, Carpobrotus chilensis, Hirschfeldia incana, Lepidium draba, Lepidium latifolium, Mesembryanthemum crystallinum, and Spartina densiflora. With the exception of S. densiflora (which occurred in 35 percent of the plots at Mad River), the frequency of occurrence of most non-native taxa was relatively small in the tidal marshes investigated in this study.

Table 5. Number of vegetation plots (upland plots excluded) and total tidal marsh vascular plant richness across six study sites in California.

[Sites are ordered from north to south]

\begin{tabular}{lcc}
\hline \multicolumn{1}{c}{ Site } & $\begin{array}{c}\text { Plots } \\
\text { sampled }\end{array}$ & $\begin{array}{c}\text { Total plant } \\
\text { richness }\end{array}$ \\
\hline Mad River & 173 & 24 \\
Bolinas & 308 & 21 \\
Morro Bay & 616 & 16 \\
Pt. Mugu & 373 & 16 \\
Newport & 248 & 20 \\
Tijuana & 309 & 17 \\
\hline
\end{tabular}




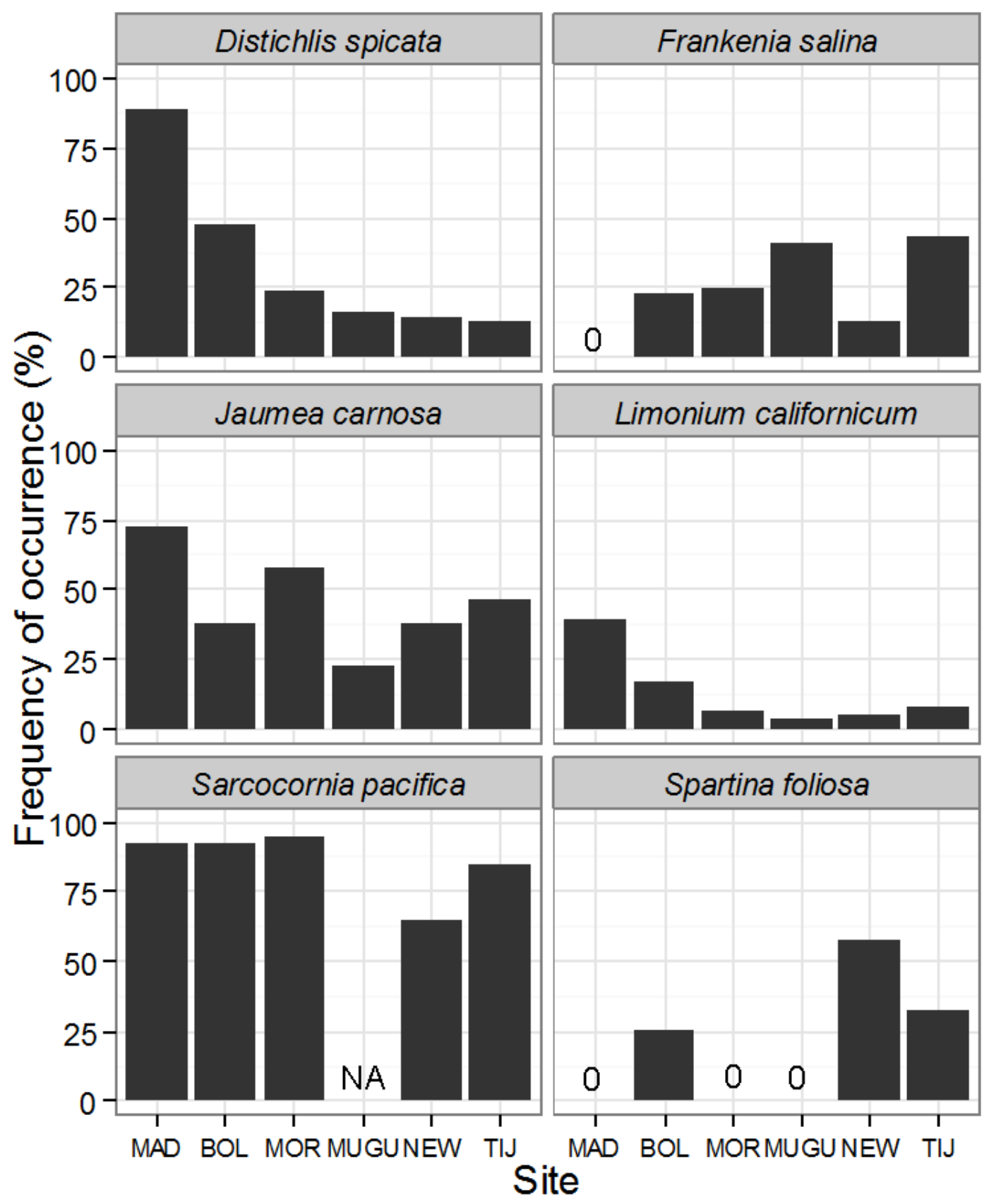

Figure 19. Frequency of occurrence (percentage of all vegetation plots [\%]) of six dominant and sub-dominant marsh species across six marshes in California. MAD, Mad River; BOL, Bolinas; MOR, Morro; MUGU, Pt. Mugu; NEW, Newport; and TIJ, Tijuana. NA indicates Not Applicable and 0 indicates that species was not present. 


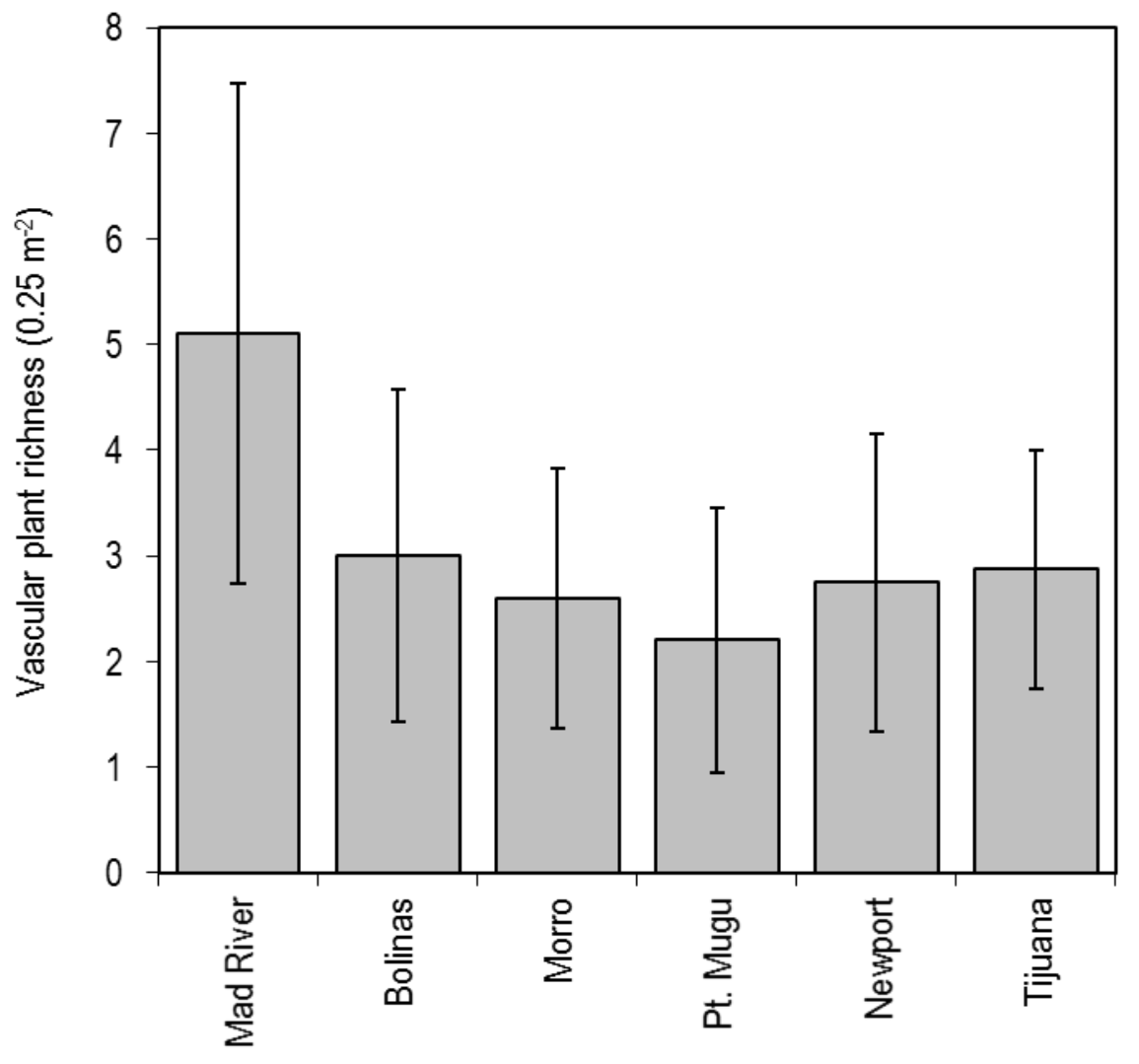

Figure 20. Mean ( \pm standard deviation) vascular plant richness (species [spp.] per 0.25 square meters [m²]) in vegetation plots at six sites in California. Sites are ordered from north to south. 


\subsection{Water Monitoring}

Water-level and salinity loggers recorded peak tide levels and salinity throughout the study duration, and we continue to monitor several sites for future analyses. Loggers did not capture the lower portions of the tidal curve because they were located in marsh channels which frequently completely drain at low tide. We used peak water levels to derive site-specific tidal datums (mean high water $[\mathrm{MHW}]$ and mean higher high water $[\mathrm{MHHW}]$ ) and information on the highest observed water level (HOWL) during the time series (table 6). Our tidal datum computations generally matched tidal datums computed at nearby NOAA stations (http://tidesandcurrents.noaa.gov), but represent site-specific conditions that may be affected by spatial differences in estuarine hydrology such as spatial variability in tidal amplitude.

Conductivity logger data show relatively high salinities (polyhaline to euhaline conditions) at most of the sites for the time period investigated (fig. 21). Weekly maximum salinity generally remained at, or close to, that of sea water, particularly for coastal sites. However, lower salinities during late winter and early spring at Mad River suggested some freshwater inputs from spring precipitation. San Pablo remained the freshest site during the period examined, possibly because of drainage of the nearby Petaluma River and the Sacramento and San Joaquin Rivers through San Pablo Bay. With recent drought conditions in California (winter 2013-summer 2015), observed salinities may have been higher than average winter conditions at these sites.

Table 6. Tidal datums calculated from water-level loggers deployed at each study site in California.

[Sites are ordered from north to south. All tidal datums are in meters, North American Vertical Datum 88 with Geoid 09. HOWL, highest observed water level; MHHW, mean higher high water; MHW, mean high water; MTL, mean tide level]

\begin{tabular}{|c|c|c|c|c|c|c|}
\hline \multirow{2}{*}{ Site } & \multirow{2}{*}{ Data source } & \multirow{2}{*}{$\begin{array}{l}\text { Time series } \\
\text { length }\end{array}$} & \multicolumn{4}{|c|}{ NAVD88 elev with Geoid 09 (m) } \\
\hline & & & HOWL & MHHW & MHW & MTL \\
\hline Mad River & CERCC, logger MAD01/02 & 9 months & 2.726 & 2.005 & 1.786 & $\begin{array}{l}1,4 \\
1,4952\end{array}$ \\
\hline Bolinas & NOAA stn 9412110 , Bolinas & 35 months & ${ }^{2} 2.427$ & ${ }^{2} 1.633$ & ${ }^{2} 1.448$ & ${ }^{2} 0.990$ \\
\hline Morro Bay & CERCC, logger Morro01 & $\begin{array}{l}\text { about } 12 \\
\text { months }\end{array}$ & 2.208 & 1.652 & 1.439 & $0.868^{\mathrm{a}}$ \\
\hline Pt. Mugu & VDATUM model & NA & NA & ${ }^{1,3} 1.600$ & ${ }^{1,3} 1.386$ & $1,30.822$ \\
\hline Newport Bay & CERCC, logger NB01 & 6 months & 2.346 & 1.599 & 1.383 & 0.780 \\
\hline Tijuana Estuary & CERCC, logger TJ04 & $\begin{array}{r}\text { about } 12 \\
\text { months }\end{array}$ & 2.131 & 1.559 & 1.365 & $1,30.769$ \\
\hline
\end{tabular}

${ }^{1}$ Derived from the VDATUM model.

${ }^{2}$ Obtained from nearby National Oceanic and Atmospheric Administration station.

${ }^{3}$ Computed at the mouth of the estuary.

${ }^{4}$ Computed at nearby logger location. 


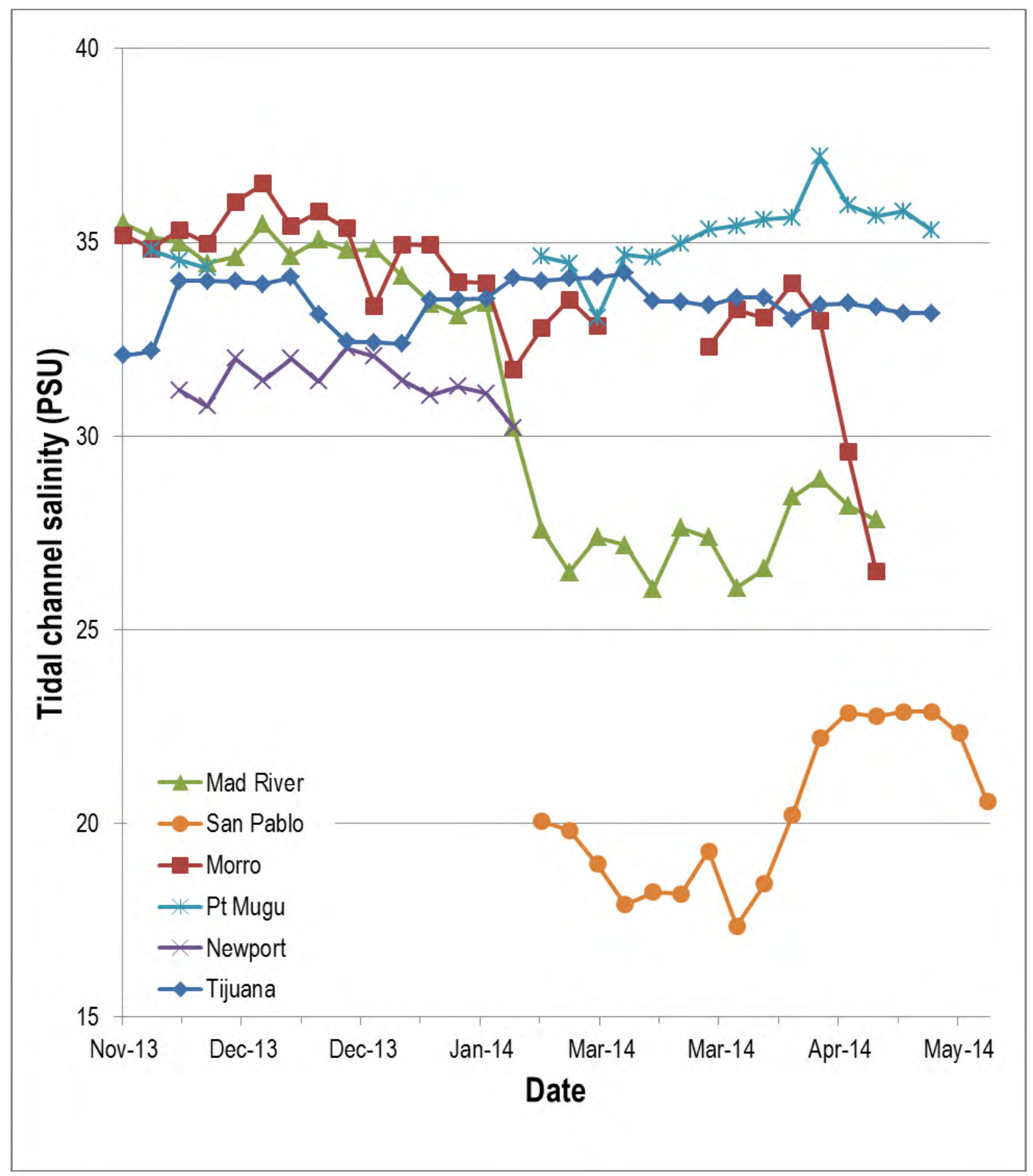

Figure 21. Weekly maximum salinity levels of all study sites where data were available, California, November 2013-June2014. Seawater has a salinity of 35 practical salinity units (PSU). 


\subsection{Bathymetry}

We collected bathymetry data at all study sites except for Tijuana, surveying a total of 811.3 ha (fig. 22; table 7). We used lidar data from the 2009-11 California Coastal Conservancy Coastal Lidar Project for Morro. Depths ranged from -7.93 and $2.81 \mathrm{~m}$ NAVD 88, due to site characteristics that included both shallow mudflat areas and deep channel systems. 


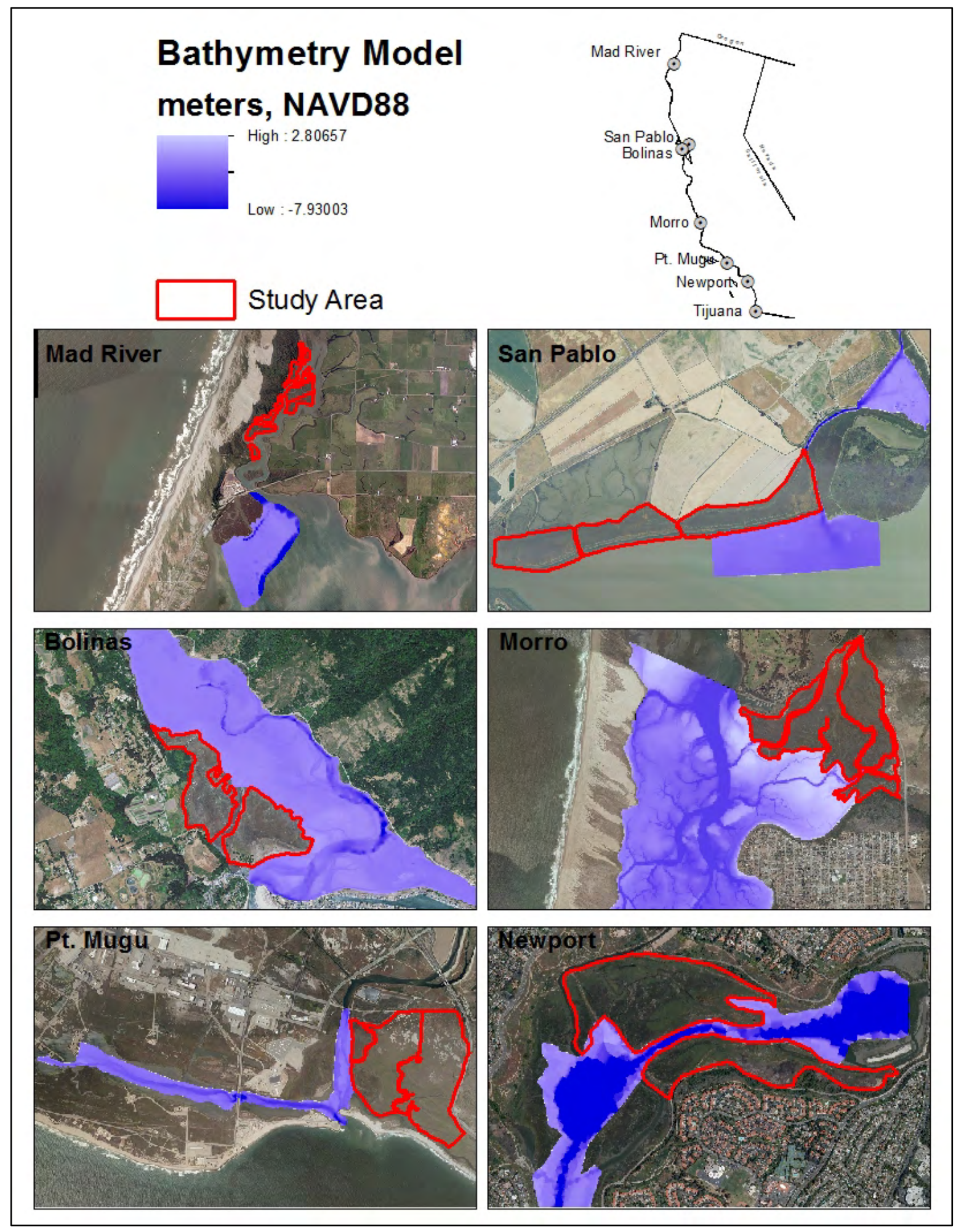

Figure 22. Bathymetry coverage across six study sites in California. Surveyed tidal marsh areas are shown as study areas. 
Table 7. Surveyed area and maximum and minimum elevations of nearshore habitat for six study sites in California.

[Sites are ordered from north to south. Elevations are in meters above North American Vertical Datum of 1988]

\begin{tabular}{|c|c|c|c|}
\hline Site & $\begin{array}{c}\text { Surveyed } \\
\text { area } \\
\text { (hectares) }\end{array}$ & $\begin{array}{l}\text { Maximum } \\
\text { elevation } \\
\text { (meters) }\end{array}$ & $\begin{array}{l}\text { Minimum } \\
\text { elevation } \\
\text { (meters) }\end{array}$ \\
\hline Mad River & 115.0 & 0.97 & -6.74 \\
\hline San Pablo & 221.6 & 2.04 & -3.81 \\
\hline Bolinas & 340.1 & 1.73 & -5.91 \\
\hline Morro $^{1}$ & 549.9 & 2.80 & -1.26 \\
\hline Pt Mugu & 54.6 & 1.21 & -7.93 \\
\hline Newport & 80.0 & 1.86 & -5.82 \\
\hline
\end{tabular}

${ }^{1}$ Bathymetry data at this site were collected using lidar.

\subsection{Paleoenvironmental Sediment Characteristics}

\section{Radiocarbon Dating Results}

Calibrated and uncalibrated ${ }^{14} \mathrm{C}$ dates from 55 sediment cores ( 71 dates) are listed in table 8 . In northern California, we obtained ${ }^{14} \mathrm{C}$ dates at Humboldt Bay and Bolinas Lagoon. Basal sediment in Humboldt Bay ranged in age from 1800 to 700 years before present (YBP) in cores 1.89-3.89 m deep. The age of the deepest sediments sampled at Eureka marsh were uncertain because of anomalous dates from marine samples in the lower $2 \mathrm{~m}$ of the core. Cores from Jacoby and Mad River Sloughs were shallower and did not show any evidence of interrupted accretion. We dated bulk sediment from one core from Bolinas Lagoon at $1.52 \mathrm{~m}$, which gave an age of about $140 \mathrm{YBP}$ after being corrected for marine carbon, which likely dominated the sample.

We also dated marsh cores from southern and central California sites using ${ }^{14} \mathrm{C}$ (Morro, Pt. Mugu, Newport, and Tijuana). The majority of samples taken from Morro were relatively young, with most plant and shell material taken from depths of 2-3 m estimated to be less than 500 years old. The oldest sample from the site (taken from a depth of $4.5 \mathrm{~m}$ ) dated to 2500 calibrated (cal) YBP. Samples from Pt. Mugu mostly dated post-1950 C.E. and probably accumulated during the last 30-60 years. The deepest sediments from Seal Beach were fairly old, ranging from $670 \mathrm{YBP}$ at $1.07 \mathrm{~m}$ to $2020 \mathrm{YBP}$ at $2.73 \mathrm{~m}$. Shells from basal sediments in Newport returned the oldest dates from this study: 5400-5600 cal YBP. The oldest sediments at Tijuana dated to 1999 cal YBP from a bulk sediment date. Dates on discrete material taken from a depth of about $1.5 \mathrm{~m}$ at Tijuana were slightly younger (as bulk sediments typically return anomalously old dates), estimated to be about 1500 cal YBP.

We obtained at least one date from each core (the lowest point) and dates from additional depths from 24 of the cores. Of the 24 multi-date cores, 10 had anomalous dates, or reversals somewhere in the core. This is troubling, as it indicates that many of these marshes were not linearly accumulating throughout their history. Anomalous dates could be due to processes such as marine radiocarbon offsets in shells due to species differences or changes in freshwater/saltwater inputs to marshes over time, older material being re-deposited by storm or wave activity, catastrophic sediment changes such as channel movement, or anthropogenic disturbance from channelization or dredging. Continued analysis of these cores will include a more nuanced modeling of marine radiocarbon offsets, additional radiocarbon dates, and Bayesian age-depth modeling to consistently eliminate outliers and identify linearly accumulating sections of marsh peat. 
Table 8. Collection data for 55 paleoenvironmental cores sampled for study sites in California.

[Plant composition: co-dom, co-dominated; dom, dominated. ${ }^{14} \mathrm{C}$ date: $\mathrm{n}$, number of radiocarbon samples. ID, identification; SET, Surface Elevation Table. $\mathrm{cm}$, centimeter, NA, Not Applicable]

\begin{tabular}{|c|c|c|c|c|c|c|c|c|c|c|c|}
\hline Site & Core ID & $\begin{array}{c}\text { Figure } \\
8 \text { ID }\end{array}$ & $\begin{array}{c}\text { Date } \\
\text { sampled }\end{array}$ & $\begin{array}{c}\text { Marsh } \\
\text { position } \\
\text { (High- } \\
\text { Middle-Low) }\end{array}$ & Plant composition & $\begin{array}{c}\text { SET } \\
\text { nearby } \\
\text { (yes/no) }\end{array}$ & $\begin{array}{l}\text { Core } \\
\text { depth } \\
(\mathrm{cm})\end{array}$ & Latitude & Longitude & $\begin{array}{l}\text { Marsh } \\
\text { peak } \\
\text { depth } \\
(\mathrm{cm}) \\
\end{array}$ & $\begin{array}{c}\text { c14 date } \\
\text { (n) }\end{array}$ \\
\hline \multirow[t]{2}{*}{$\begin{array}{l}\text { Mad } \\
\text { River }\end{array}$} & MRH14-01 & 1 & $07-15-13$ & High & $\begin{array}{l}\text { Distichlis dom. w/ } \\
\text { Frankenia }\end{array}$ & Yes & 255 & 40.873 & -124.15 & NA & NA \\
\hline & MRH14-02 & 2 & $07-15-13$ & High & $\begin{array}{l}\text { Distichlis dom. } \mathrm{w} / \\
\text { Frankenia } \\
\end{array}$ & Yes & 240 & 40.873 & -124.15 & NA & NA \\
\hline \multirow[t]{10}{*}{ Manila } & MRL14-04 & 3 & $07-15-13$ & Low & $\begin{array}{l}\text { Sarcocornia dom. } \mathrm{w} / \\
\text { Spartina densiflora }\end{array}$ & No & 100 & 40.862 & -124.15 & NA & NA \\
\hline & MRL14-05 & 4 & $07-15-13$ & Low & $\begin{array}{l}\text { Sarcocornia dom. } \mathrm{w} / \\
\quad \text { Spartina densiflora } \\
\end{array}$ & No & 146 & 40.862 & -124.15 & NA & NA \\
\hline & MRL14-06 & 5 & $07-15-13$ & Low & $\begin{array}{l}\text { Sarcocornia dom. } \mathrm{w} / \\
\text { Spartina densiflora }\end{array}$ & No & $50-150$ & 40.862 & -124.15 & NA & NA \\
\hline & MRL14-07 & 6 & $07-15-13$ & Middle & & No & 146 & 40.863 & -124.15 & NA & NA \\
\hline & MRL14-09 & 7 & $07-15-13$ & Middle & $\begin{array}{l}\text { Sarcocornia and } \\
\text { Spartina co-dom. }\end{array}$ & No & & 40.863 & -124.15 & NA & NA \\
\hline & MRL14-10 & 8 & $07-15-13$ & $\begin{array}{l}\text { Low/ } \\
\text { Middle }\end{array}$ & $\begin{array}{l}\text { Spartina densiflora } \\
\text { dom. }\end{array}$ & Yes & 100 & 40.864 & -124.15 & NA & NA \\
\hline & MRL14-11 & 9 & $07-15-13$ & $\begin{array}{l}\text { Low/ } \\
\text { Middle }\end{array}$ & $\begin{array}{l}\text { Spartina densiflora } \\
\text { dom. }\end{array}$ & Yes & 100 & 40.864 & -124.15 & NA & NA \\
\hline & MRL13-01 & 10 & $07-24-13$ & Low & Spartina densiflora & Yes & 200 & 40.864 & -124.15 & NA & ${ }^{1} 1,1$ \\
\hline & MRL13-02 & 11 & $07-24-13$ & Low & Spartina densiflora & Yes & 50 & 40.864 & -124.15 & NA & \\
\hline & MRL13-03 & 12 & $07-24-13$ & Low & Spartina densiflora & Yes & 100 & 40.864 & -124.15 & NA & ${ }^{1} 1$ \\
\hline Jacoby & JCB13-01 & 13 & $07-24-13$ & $\begin{array}{l}\text { Middle/ } \\
\text { High }\end{array}$ & $\begin{array}{l}\text { Sarcocornia } \text { and } \\
\text { Distichlis }\end{array}$ & No & 407 & 40.846 & -124.08 & NA & 2 \\
\hline Eureka & ERK13-01 & 14 & $07-24-13$ & Low & Spartina densiflora & No & 400 & 40.807 & -124.14 & NA & 4 \\
\hline \multirow[t]{4}{*}{ Bolinas } & BOL13-01 & 15 & $07-22-13$ & High & $\begin{array}{l}\text { Distichlis, sedge, } \\
\text { Sarcocornia } \mathrm{w} / \\
\text { Atriplex and } \\
\text { Grindelia }\end{array}$ & Yes & 192 & 37.92 & -122.69 & NA & 2 \\
\hline & BOL13-02 & 16 & $07-22-13$ & High & $\begin{array}{l}\text { Distichlis, sedge, } \\
\text { Sarcocornia } \mathrm{w} / \\
\text { Atriplex, Grindelia, } \\
\text { Frankenia }\end{array}$ & Yes & 200 & 37.919 & -122.69 & NA & ${ }^{\mathrm{I}} 1,1$ \\
\hline & BOL13-03 & 17 & $07-22-13$ & $\begin{array}{l}\text { Low/ } \\
\text { Middle }\end{array}$ & $\begin{array}{l}\text { Sarcocornia and } \\
\quad \text { Spartina }\end{array}$ & Yes & 141 & 37.919 & -122.69 & NA & 2 \\
\hline & BOL13-04 & 18 & $07-22-13$ & Low/ & Sarcocornia and & No & 124 & 37.918 & -122.69 & NA & NA \\
\hline
\end{tabular}




\begin{tabular}{|c|c|c|c|c|c|c|c|c|c|c|c|}
\hline Site & Core ID & $\begin{array}{l}\text { Figure } \\
8 \text { ID }\end{array}$ & $\begin{array}{l}\text { Date } \\
\text { sampled }\end{array}$ & $\begin{array}{c}\text { Marsh } \\
\text { position } \\
\text { (High- } \\
\text { Middle-Low) }\end{array}$ & Plant composition & $\begin{array}{c}\text { SET } \\
\text { nearby } \\
\text { (yes/no) }\end{array}$ & $\begin{array}{l}\text { Core } \\
\text { depth } \\
(\mathrm{cm})\end{array}$ & Latitude & Longitude & $\begin{array}{l}\text { Marsh } \\
\text { peak } \\
\text { depth } \\
(\mathrm{cm})\end{array}$ & $\begin{array}{l}\text { c14 date } \\
\text { (n) }\end{array}$ \\
\hline & & & & Middle & Spartina & & & & & & \\
\hline & BOL13-05 & 19 & $07-22-13$ & $\begin{array}{l}\text { Low/ } \\
\text { Middle }\end{array}$ & $\begin{array}{l}\text { Sarcocornia } \text { and } \\
\text { Spartina }\end{array}$ & No & 141 & 37.916 & -122.69 & NA & NA \\
\hline \multirow[t]{11}{*}{ Morro } & MOB13-01 & 20 & $03-01-13$ & Middle & $\begin{array}{l}\text { Sarcocornia dom. w/ } \\
\text { Jaumea and } \\
\text { Limonium } \\
\end{array}$ & Yes & 260 & 35.341 & -120.84 & 63 & 2 \\
\hline & MOB13-02 & 21 & $03-01-13$ & Middle & $\begin{array}{l}\text { Sarcocornia dom. w/ } \\
\text { Jaumea and } \\
\text { Limonium } \\
\end{array}$ & Yes & 320 & 35.341 & -120.84 & $\mathrm{NA}$ & 3 \\
\hline & MOB13-03 & 22 & $03-01-13$ & $\begin{array}{l}\text { Middle/ } \\
\text { High }\end{array}$ & Sarcocornia & No & 270 & 35.343 & -120.84 & NA & 1 \\
\hline & MOB13-04 & 23 & $03-01-13$ & $\begin{array}{l}\text { Middle/ } \\
\text { High }\end{array}$ & Sarcocornia & No & 200 & 35.345 & -120.83 & NA & 1 \\
\hline & MOB13-05 & 24 & 03-01-13 & $\begin{array}{l}\text { Middle/ } \\
\text { High } \\
\end{array}$ & Sarcocornia & No & 200 & 35.344 & -120.83 & NA & NA \\
\hline & MOB13-06 & 25 & $03-01-13$ & $\begin{array}{l}\text { Middle/ } \\
\text { High }\end{array}$ & Sarcocornia & No & 100 & 35.346 & -120.83 & NA & 1 \\
\hline & MOB13-07 & 26 & $03-01-13$ & $\begin{array}{l}\text { Middle/ } \\
\text { High }\end{array}$ & Sarcocornia & No & 350 & 35.346 & -120.83 & 95 & 3 \\
\hline & MOB13-08 & 27 & $03-01-13$ & $\begin{array}{l}\text { Middle/ } \\
\text { High }\end{array}$ & Sarcocornia & Yes & 150 & 35.347 & -120.83 & 137 & ${ }^{\mathrm{I}} 3,1$ \\
\hline & MOB13-09 & 28 & 03-01-13 & $\begin{array}{l}\text { Middle/ } \\
\text { High }\end{array}$ & Sarcocornia & Yes & 200 & 35.347 & -120.83 & 124 & 2,1 \\
\hline & MOB13-10 & 29 & 03-01-13 & Middle & $\begin{array}{l}\text { Sarcocornia } \text { dom. w/ } \\
\quad \text { Jaumea }\end{array}$ & No & 200 & 35.343 & -120.84 & NA & 1 \\
\hline & MOB13-11 & 30 & $03-01-13$ & Middle & $\begin{array}{l}\text { Sarcocornia dom. w/ } \\
\text { Jaumea, Frankenia, } \\
\text { Distichlis }\end{array}$ & No & 200 & 35.342 & -120.84 & NA & 1 \\
\hline \multirow[t]{6}{*}{ Pt. Mugu } & MGL13-01 & 31 & $01-18-13$ & Middle & $\begin{array}{l}\text { Sarcocornia and } \\
\quad \text { Jaumea }\end{array}$ & Yes & 106 & 34.104 & -119.09 & NA & NA \\
\hline & MGL13-02 & 32 & $01-18-13$ & Middle & $\begin{array}{l}\text { Sarcocornia and } \\
\text { Jaumea }\end{array}$ & No & 97 & 34.105 & -119.09 & NA & NA \\
\hline & MOB13-09 & 28 & $03-01-13$ & $\begin{array}{l}\text { Middle/ } \\
\text { High }\end{array}$ & Sarcocornia & Yes & 200 & 35.347 & -120.83 & 124 & ${ }^{1} 2,1$ \\
\hline & MOB13-10 & 29 & 03-01-13 & Middle & $\begin{array}{l}\text { Sarcocornia } \text { dom. w/ } \\
\quad \text { Jaumea }\end{array}$ & No & 200 & 35.343 & -120.84 & $\mathrm{NA}$ & 1 \\
\hline & MGL13-03 & 33 & $01-18-13$ & Middle & $\begin{array}{l}\text { Sarcocornia dom. w/ } \\
\text { Suaeda, Frankenia, } \\
\text { Limonium }\end{array}$ & No & 60 & 34.101 & -119.09 & NA & NA \\
\hline & MGL13-04 & 34 & $01-18-13$ & Middle & $\begin{array}{l}\text { Sarcocornia dom. w/ } \\
\text { Suaeda, Frankenia, } \\
\text { Limonium }\end{array}$ & No & 48 & 34.101 & -119.09 & NA & NA \\
\hline
\end{tabular}




\begin{tabular}{|c|c|c|c|c|c|c|c|c|c|c|c|}
\hline \multirow[t]{4}{*}{ Site } & Core ID & $\begin{array}{c}\text { Figure } \\
8 \text { ID }\end{array}$ & $\begin{array}{c}\text { Date } \\
\text { sampled }\end{array}$ & $\begin{array}{c}\text { Marsh } \\
\text { position } \\
\text { (High- } \\
\text { Middle-Low) }\end{array}$ & Plant composition & $\begin{array}{c}\text { SET } \\
\text { nearby } \\
\text { (yes/no) }\end{array}$ & $\begin{array}{l}\text { Core } \\
\text { depth } \\
\text { (cm) }\end{array}$ & Latitude & Longitude & $\begin{array}{l}\text { Marsh } \\
\text { peak } \\
\text { depth } \\
(\mathrm{cm})\end{array}$ & $\begin{array}{c}\text { c14 date } \\
\text { (n) }\end{array}$ \\
\hline & MGL13-05 & 35 & $01-18-13$ & Middle & $\begin{array}{l}\text { Sarcocornia dom., w/ } \\
\text { Frankenia }\end{array}$ & No & 110 & 34.103 & -119.09 & NA & ${ }^{1} 1$ \\
\hline & MGL13-06 & 36 & $01-18-13$ & Middle & $\begin{array}{l}\text { Sarcocornia dom., w/ } \\
\text { Frankenia }\end{array}$ & No & 64 & 34.103 & -119.09 & NA & ${ }^{1} 1$ \\
\hline & MGL13-07 & 37 & $01-18-13$ & High & $\begin{array}{l}\text { Jaumea and Distichlis } \\
\text { dom. w/ } \\
\text { Sarcocornia }\end{array}$ & Yes & 72 & 34.103 & -119.09 & NA & NA \\
\hline & MGL13-08 & 38 & $01-18-13$ & High & $\begin{array}{l}\text { Jaumea and Distichlis } \\
\text { dom. w/ } \\
\text { Sarcocornia }\end{array}$ & No & 67 & 34.105 & -119.09 & NA & ${ }^{1} 1$ \\
\hline & MGL13-07 & 37 & $01-18-13$ & High & $\begin{array}{l}\text { Jaumea and Distichlis } \\
\text { dom. w/ } \\
\text { Sarcocornia }\end{array}$ & Yes & 72 & 34.103 & -119.09 & NA & NA \\
\hline & MGL13-08 & 38 & $01-18-13$ & High & $\begin{array}{l}\text { Jaumea and Distichlis } \\
\text { dom. w/ } \\
\text { Sarcocornia }\end{array}$ & No & 67 & 34.105 & -119.09 & NA & ${ }^{1} 1$ \\
\hline & MGL13-09 & 39 & $01-18-13$ & NA & $\begin{array}{c}\text { All major marsh } \\
\text { species coexist }\end{array}$ & No & 53 & 34.099 & -119.08 & NA & NA \\
\hline \multirow[t]{8}{*}{ Newport } & UNB13-01 & 40 & $02-06-13$ & High & $\begin{array}{l}\text { Sarcocornia } \text { and } \\
\text { Jaumea } \text { dom. w/ } \\
\text { Batis }\end{array}$ & No & 100 & 33.652 & -117.88 & 100 & ${ }^{1} 1,1$ \\
\hline & UNB13-02 & 41 & $02-06-13$ & High & $\begin{array}{l}\text { Sarcocornia } \text { dom. w/ } \\
\text { Spartina, Batis, } \\
\text { Cuscuta }\end{array}$ & No & 250 & 33.652 & -117.88 & 105 & ${ }^{1} 1,1$ \\
\hline & UNB13-03 & 42 & $02-06-13$ & $\begin{array}{l}\text { High/ } \\
\text { Middle }\end{array}$ & $\begin{array}{l}\text { Spartina } \text { dom. w/ } \\
\text { Sarcocornia }\end{array}$ & No & 360 & 33.651 & -117.88 & 90 & 1 \\
\hline & UNB13-04 & 43 & $02-06-13$ & Middle & $\begin{array}{l}\text { Spartina, Batis, } \\
\text { Jaumea dom. }\end{array}$ & No & 600 & 33.65 & -117.88 & 143 & ${ }^{1} 3,1$ \\
\hline & UNB14-05 & 44 & $02-21-14$ & Low & Spartina foliosa dom. & Yes & 300 & 33.648 & -117.88 & NA & 2 \\
\hline & UNB14-06 & 45 & $02-21-14$ & Low & Spartina foliosa dom. & Yes & 300 & 33.648 & -117.88 & NA & 2 \\
\hline & UNB14-07 & 46 & $02-21-14$ & High & Sarcocornia dom. & Yes & 200 & 33.652 & -117.88 & NA & 2 \\
\hline & UNB14-08 & 47 & $02-21-14$ & High & Sarcocornia dom. & Yes & 169 & 33.652 & -117.88 & NA & ${ }^{1} 1,1$ \\
\hline \multirow[t]{4}{*}{ Tijuana } & TJE12-1 & 48 & $09-06-12$ & Low & $\begin{array}{r}\text { Sarcocornia, some } \\
\text { Spartina foliosa } \\
\end{array}$ & No & 204 & 32.573 & -117.13 & 140 & 1 \\
\hline & TJE12-2 & 49 & $09-06-12$ & Low & Spartina foliosa & No & 197 & 32.573 & -117.13 & NA & NA \\
\hline & TJE12-3 & 50 & 09-06-12 & Middle & $\begin{array}{l}\text { Sarcocornia } \text { dom. w/ } \\
\text { Jaumea, Cuscuta } \\
\text { and Batis }\end{array}$ & No & 94 & 32.574 & -117.13 & NA & ${ }^{1} 2$ \\
\hline & TJE12-4 & 51 & $09-06-12$ & Middle & $\begin{array}{l}\text { Sarcocornia } \text { dom. w/ } \\
\text { Jaumea, Cuscuta } \\
\text { and Batis }\end{array}$ & No & 79 & 32.574 & -117.13 & NA & ${ }^{1} 2$ \\
\hline
\end{tabular}




\begin{tabular}{|c|c|c|c|c|c|c|c|c|c|c|c|}
\hline Site & Core ID & $\begin{array}{l}\text { Figure } \\
8 \text { ID }\end{array}$ & $\begin{array}{c}\text { Date } \\
\text { sampled }\end{array}$ & $\begin{array}{c}\text { Marsh } \\
\text { position } \\
\text { (High- } \\
\text { Middle-Low) }\end{array}$ & Plant composition & $\begin{array}{c}\text { SET } \\
\text { nearby } \\
\text { (yes/no) }\end{array}$ & $\begin{array}{l}\text { Core } \\
\text { depth } \\
(\mathrm{cm})\end{array}$ & Latitude & Longitude & $\begin{array}{l}\text { Marsh } \\
\text { peak } \\
\text { depth } \\
(\mathrm{cm})\end{array}$ & $\begin{array}{l}\text { c14 date } \\
\text { (n) }\end{array}$ \\
\hline & TJE12-5 & 52 & 09-06-12 & $\begin{array}{l}\text { Middle/ } \\
\text { High }\end{array}$ & Sarcocornia & Yes & 40 & 32.575 & -117.13 & NA & NA \\
\hline & TJE12-6 & 53 & $09-06-12$ & $\begin{array}{l}\text { Middle/ } \\
\text { High }\end{array}$ & Sarcocornia & Yes & 98 & 32.575 & -117.13 & NA & 2 \\
\hline & TJE12-7 & 54 & $09-06-12$ & $\begin{array}{l}\text { Middle/ } \\
\text { Low }\end{array}$ & Jaumea, Sarcocornia & Yes & 136 & 32.575 & -117.13 & 67 & 2 \\
\hline & TJE12-8 & 55 & $09-06-12$ & $\begin{array}{l}\text { Middle/ } \\
\text { Low }\end{array}$ & $\begin{array}{l}\text { Jaumea and } \\
\text { Sarcocornia dom., } \\
\text { w/ Spartina foliosa }\end{array}$ & Yes & 148 & 32.575 & -117.13 & 87 & 1 \\
\hline
\end{tabular}

${ }^{1}$ Accretion rates inferred from post-1950 Common Era ${ }^{14} \mathrm{C}$ dates. 


\section{Radiocesium Dating Results}

Of the eight cores submitted for ${ }^{137} \mathrm{Cs}$ analysis, five had definite peaks indicating the 1963 C.E. time horizon (table 9). Results from Bolinas Lagoon, UNB13-04, and TJE12-07 presently are inconclusive because of low atmospheric fallout of radioisotopes, mobility of ${ }^{137} \mathrm{Cs}$ in sediments following deposition, or coarse sampling resolution. Future analysis would include resolving 1963 C.E. peaks to resolutions of $1-2 \mathrm{~cm}$.

Table 9. Collection data for radiocesium samples taken from five cores from four study sites in California.

[Sites are ordered from north to south. Cesium-137 $\left({ }^{137} \mathrm{Cs}\right)$ activity is shown in disintegrations per minute per gram $(\mathrm{dpm} / \mathrm{g})$ for each sample submitted. Peak ${ }^{137} \mathrm{Cs}$ (about 1963) indicated in bold for three of the five cores that showed definitive results. We calculated short-term accretion rates using the ${ }^{137} \mathrm{Cs}$ peak. ID, identification; $\pm \mathrm{SD}$, plus or minus standard deviation. cm, centimeter; mm/yr, millimeter per year, NA, Not Applicable]

\begin{tabular}{|c|c|c|c|c|c|}
\hline Site & Core ID & $\begin{array}{c}\text { Sample } \\
\text { depth } \\
\text { (cm) }\end{array}$ & $\begin{array}{c}{ }^{137} \text { Cs activity } \\
(\mathrm{dpm} / \mathrm{g})\end{array}$ & $\begin{array}{c} \pm \text { SD } \\
(\mathrm{dpm} / \mathrm{g})\end{array}$ & $\begin{array}{c}\text { Accretion rate } \\
(\mathrm{mm} / \mathrm{yr})\end{array}$ \\
\hline \multirow[t]{6}{*}{ Bolinas } & \multirow[t]{6}{*}{ BOL13-01 } & 3 & 0.23 & 0.20 & NA \\
\hline & & 9 & 0.23 & 0.11 & NA \\
\hline & & 15 & 0.11 & 0.09 & NA \\
\hline & & 19 & 0.01 & 0.08 & NA \\
\hline & & 23 & 0.31 & 0.09 & NA \\
\hline & & 29 & 0.26 & 0.11 & NA \\
\hline \multirow[t]{5}{*}{ Morro } & \multirow[t]{5}{*}{ MOB13-01 } & 2 & 1.07 & 0.24 & NA \\
\hline & & 10 & 1.10 & 0.20 & 2.0 \\
\hline & & 20 & 0.05 & 0.16 & NA \\
\hline & & 40 & 0.00 & 0.19 & NA \\
\hline & & 60 & 0.00 & 0.09 & NA \\
\hline \multirow[t]{11}{*}{ Newport } & \multirow[t]{6}{*}{ UNB13-03 } & 3 & 0.00 & 0.30 & NA \\
\hline & & 5 & 0.00 & 0.23 & NA \\
\hline & & 9 & 0.27 & 0.14 & NA \\
\hline & & 11 & 0.32 & 0.13 & NA \\
\hline & & 13 & 0.50 & 0.18 & 2.6 \\
\hline & & 17 & 0.00 & 0.10 & NA \\
\hline & \multirow[t]{5}{*}{ UNB13-04 } & 3 & 0.15 & 0.23 & NA \\
\hline & & 11 & 0.31 & 0.19 & NA \\
\hline & & 17 & 0.00 & 0.10 & NA \\
\hline & & 19 & 0.32 & 0.14 & NA \\
\hline & & 23 & 0.02 & 0.13 & NA \\
\hline \multirow[t]{5}{*}{ Tijuana } & \multirow[t]{5}{*}{ TJE12-07 } & 2 & 0.35 & 0.27 & NA \\
\hline & & 4 & 0.26 & 0.18 & NA \\
\hline & & 8 & 0.55 & 0.17 & NA \\
\hline & & 10 & 0.47 & 0.20 & NA \\
\hline & & 12 & 0.69 & 0.19 & $>4.1$ \\
\hline
\end{tabular}




\section{Accretion Rates}

Accretion rates for all cores are shown in tables 10 and 11 and summarized as mean long-term accretion and accretion since the 1950 s by site in table 11. Long-term accretion rates for southern California marshes generally were lower than rates for northern California marshes (fig. 23; table 11). Humboldt Bay accretion rates were moderate over the last 1,000-500 years, averaging $3.5 \pm 0.2 \mathrm{~mm} / \mathrm{yr}$. Bolinas had the most variable accumulation rates within a site (a maximum of $6.1 \mathrm{~mm} / \mathrm{yr}$ and a minimum of $0.6 \mathrm{~mm} / \mathrm{yr}$ ) because of high dating uncertainty and possibly the effects of earthquakes.

Morro presented a different sedimentation environment than the other marshes in this study and showed a high amount of variability in mean accretion rate from core to core $(8.1 \pm 4.6 \mathrm{~mm} / \mathrm{yr})$. Tijuana had the lowest rates of accretion of all study sites $(1.1 \pm 0.8 \mathrm{~mm} / \mathrm{yr})$. Newport had somewhat higher rates of accretion at $2.8 \pm 2.3 \mathrm{~mm} / \mathrm{yr}$.

We also reported accretion rates since the $1960 \mathrm{~s}$ using ${ }^{137} \mathrm{Cs}$ dates and post-bomb ${ }^{14} \mathrm{C}$ dates (tables 10 and 11). Post-bomb ${ }^{14} \mathrm{C}$ from Humboldt Bay cores indicated that recent accretion has ranged from 4.9 to $5.7 \mathrm{~mm} / \mathrm{yr}$. A single core from Bolinas suggested high rates of recent accretion $(21.2$ $\mathrm{mm} / \mathrm{yr}$ ). Morro Bay had a $1963{ }^{137} \mathrm{Cs}$ peak at relatively shallow depth, indicating low accretion. Pt. Mugu had the highest accretion rates of the study, averaging $14.4 \pm 6.4 \mathrm{~mm} / \mathrm{yr}$, based on post-bomb ${ }^{14} \mathrm{C}$ dates. One core from Newport suggested low accretion since 1963 C.E. (2.6 mm/yr). At Tijuana, ${ }^{137} \mathrm{Cs}$ dating was inconclusive, but accretion was greater than $4.1 \mathrm{~mm} / \mathrm{yr}$, and ranged from 2.1 to $12.3 \mathrm{~mm} / \mathrm{yr}$ in a previous study (Weis and others, 2001). In future studies, we plan to increase the number of cores with ${ }^{137} \mathrm{Cs}$ dates to characterize differences among high, middle, and low marsh habitats at each site.

Our ${ }^{14} \mathrm{C}$ and ${ }^{137} \mathrm{Cs}$-inferred accretion rate estimates show that recent accretion rates tended to be higher than multi-centennial to millennial accretion rates. Of the 14 cores that had multiple reliable ${ }^{14} \mathrm{C}$ dates, 11 of them showed an increase in accretion rates during the most recent time period (average of 5 $\mathrm{mm} / \mathrm{yr}$ ). The same pattern was true for the three cores that had both reliable ${ }^{137} \mathrm{Cs}$ and ${ }^{14} \mathrm{C}$ dates; accretion rates calculated from the ${ }^{137} \mathrm{Cs}$ dates were $2.2 \mathrm{~mm} / \mathrm{yr}$ higher on average. Apparent acceleration in accretion in the recent past may be due to increased compaction and belowground carbon loss in deeper sediments, increased sedimentation because of recent colonization of sediment by marsh vegetation, increased upland erosion starting approximately 200 years ago from the introduction of ranching, or a combination of factors. 
Table 10. Collection data for 71 radiocarbon samples taken from 37 cores and submitted to the University of California, Irvine, Keck Carbon Cycle Accelerator Mass Spectrometry Laboratory for analysis.

[Sites are ordered from north to south. These results were used to calculate long-term accretion rates given on the right side of the table. The mean probable age for each sample was used to calculate the number of years of accretion from the collection date to the sample. C.E., Common Era; ID, identification; \pm SD, plus or minus standard deviation; YBP, years before present. $\mathrm{cm}$, centimeter; $\mathrm{mm} / \mathrm{yr}$, millimeter per year]

\begin{tabular}{|c|c|c|c|c|c|c|c|c|c|c|c|}
\hline Site & Core ID & $\begin{array}{c}\text { Collection } \\
\text { year } \\
\text { (C.E.) } \\
\end{array}$ & $\begin{array}{l}\text { Sample } \\
\text { depth } \\
\text { (cm) }\end{array}$ & Material & $\begin{array}{c}{ }^{14} \mathrm{C} \\
\text { age } \\
\text { (YBP) }\end{array}$ & $\begin{array}{l} \pm \text { SD } \\
\text { (YBP) }\end{array}$ & & $\begin{array}{l}\text { ge range } \\
\text { YBP) }\end{array}$ & $\begin{array}{c}\text { Median } \\
\text { age } \\
\text { (YBP) }\end{array}$ & $\begin{array}{l}\text { Years of } \\
\text { accretion }\end{array}$ & $\begin{array}{c}\text { Accretion } \\
\text { rate } \\
\text { (mm/yr) }\end{array}$ \\
\hline \multirow[t]{4}{*}{ Eureka } & ${ }^{1}$ ERK13-01 & 2013 & 73 & Organic & 125 & 20 & 12 & to 269 & 115 & 178 & 4.1 \\
\hline & & & 130 & Organic & 435 & 20 & 479 & to 520 & 504 & 567 & 2.3 \\
\hline & & & 272 & Marine & 1760 & 20 & 828 & to 1252 & 1039 & 1102 & 2.5 \\
\hline & & & 389 & Marine & 1740 & 20 & 798 & to 1232 & 1019 & 1082 & 3.6 \\
\hline \multirow[t]{2}{*}{ Jacoby } & JCB13-01 & 2013 & 140 & Marine & 735 & 20 & 1 & to 270 & 119 & 182 & 7.7 \\
\hline & & & 228 & Organic & 675 & 20 & 564 & to 673 & 655 & 718 & 3.2 \\
\hline \multirow[t]{3}{*}{ Manila } & MRL13-01 & 2013 & 23 & Organic & -3550 & 25 & -13 & to -20 & -17 & 46 & 4.9 \\
\hline & & & 198 & Organic & 400 & 20 & 334 & to 508 & 485 & 548 & 3.6 \\
\hline & MRL13-03 & 2013 & 24 & Organic & -1990 & 20 & -12 & to -32 & -22 & 41 & 5.7 \\
\hline \multirow[t]{6}{*}{ Bolinas } & ${ }^{1}$ BOL13-01 & 2013 & 47 & Marine & 160 & 25 & 1 & to 285 & 182 & 245 & 1.9 \\
\hline & & & 141 & Marine & 815 & 20 & 1 & to 360 & 170 & 233 & 6.1 \\
\hline & BOL13-02 & 2013 & 96 & Organic & -3205 & 25 & -13 & to -24 & -18 & 45 & 21.1 \\
\hline & & & 176 & Marine & 3365 & 20 & 2687 & to 3146 & 2879 & 2942 & 0.6 \\
\hline & ${ }^{1} \mathrm{BOL} 13-03$ & 2013 & 55 & Marine & 430 & 20 & 475 & to 518 & 502 & 565 & 1.0 \\
\hline & & & 97 & Marine & 695 & 20 & 283 & to 411 & 341 & 404 & 2.4 \\
\hline \multirow[t]{8}{*}{ Morro } & MOB13-01 & 2013 & 198 & Organic & 765 & 15 & 1 & to 254 & 120 & 183 & 10.8 \\
\hline & & & 256 & Marine & 780 & 15 & 1 & to 262 & 131 & 194 & 13.2 \\
\hline & $\begin{array}{c}{ }^{\mathrm{T}} \text { MOB13- } \\
02^{*}\end{array}$ & 2013 & 51 & Organic & 175 & 15 & 1 & to 283 & 186 & 249 & 2.0 \\
\hline & & & 199 & Marine & 810 & 15 & 1 & to 285 & 155 & 218 & 9.1 \\
\hline & & & 317 & Marine & 975 & 20 & 145 & to 483 & 341 & 404 & 7.8 \\
\hline & MOB13-03 & 2013 & 268 & Marine & 825 & 15 & 1 & to 303 & 167 & 230 & 11.7 \\
\hline & MOB13-04 & 2013 & 249 & Organic & 80 & 20 & 32 & to 256 & 97 & 160 & 15.6 \\
\hline & MOB13-06 & 2013 & 98 & Marine & 1030 & 15 & 254 & to 511 & 383 & 446 & 2.2 \\
\hline
\end{tabular}




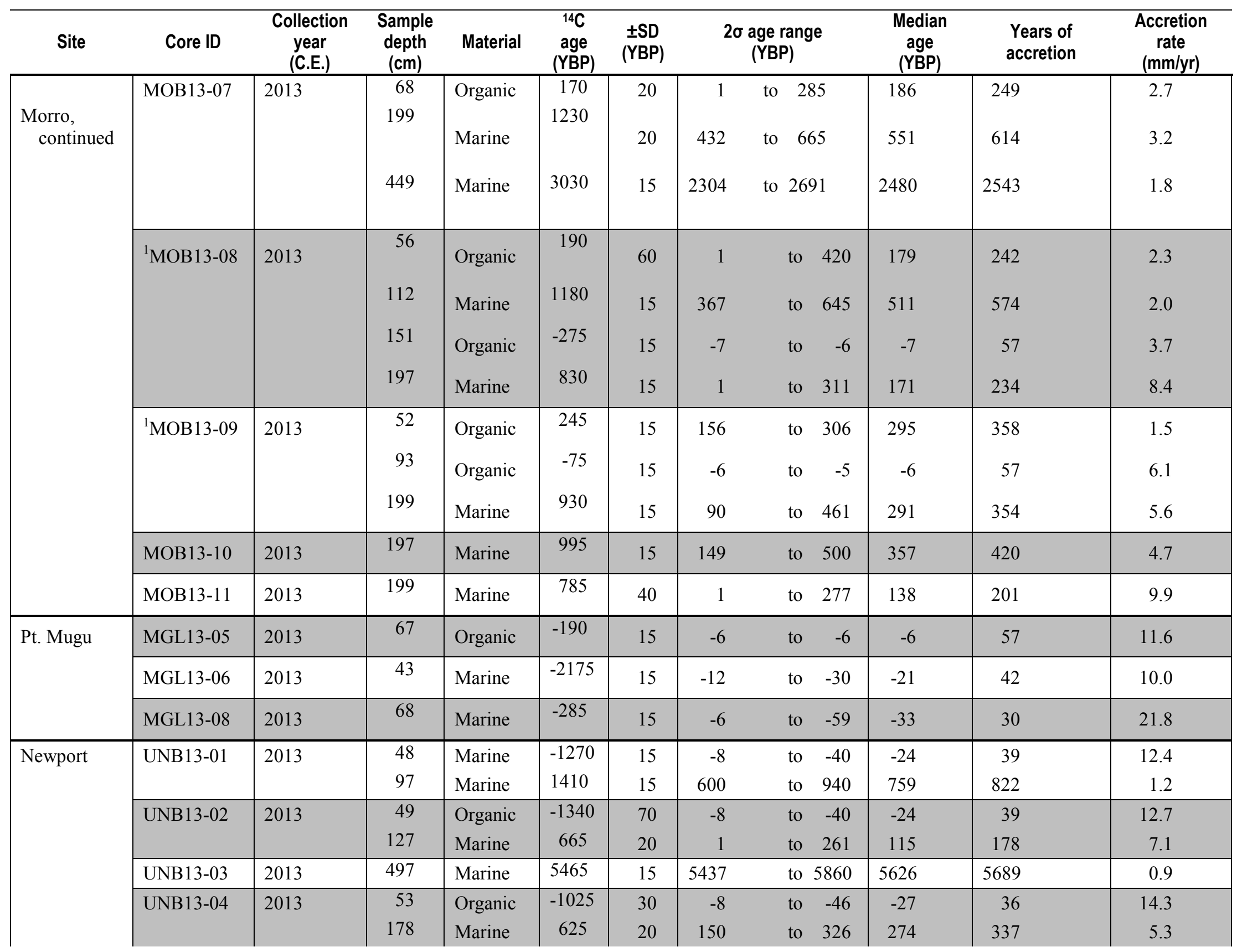




\begin{tabular}{|c|c|c|c|c|c|c|c|c|c|c|c|}
\hline Site & Core ID & $\begin{array}{l}\text { Collection } \\
\text { year } \\
\text { (C.E.) }\end{array}$ & $\begin{array}{c}\text { Sample } \\
\text { depth } \\
\text { (cm) }\end{array}$ & Material & $\begin{array}{c}{ }^{14} \mathrm{C} \\
\text { age } \\
\text { (YBP) }\end{array}$ & $\begin{array}{c} \pm S D \\
\text { (YBP) }\end{array}$ & & $\begin{array}{l}\text { range } \\
\text { D) }\end{array}$ & $\begin{array}{c}\text { Median } \\
\text { age } \\
\text { (YBP) }\end{array}$ & $\begin{array}{l}\text { Years of } \\
\text { accretion }\end{array}$ & $\begin{array}{c}\text { Accretion } \\
\text { rate } \\
\text { (mm/yr) }\end{array}$ \\
\hline \multirow{10}{*}{$\begin{array}{l}\text { Newport, } \\
\text { continued }\end{array}$} & \multirow[t]{2}{*}{$\begin{array}{l}\text { UNB13-04, } \\
\text { Cont. }\end{array}$} & & 232 & & 830 & 20 & 1 & & 259 & 322 & 7.2 \\
\hline & & & 600 & Marine & 5240 & 25 & 5119 & to 5587 & 5385 & 5448 & 1.1 \\
\hline & \multirow[t]{2}{*}{ UNB14-05 } & \multirow[t]{2}{*}{2014} & 119 & Marine & 635 & 20 & 238 & to 354 & 280 & 344 & 3.5 \\
\hline & & & 297 & Marine & 2620 & 20 & 1842 & to 2295 & 2054 & 2118 & 1.4 \\
\hline & \multirow[t]{2}{*}{ UNB14-06 } & \multirow[t]{2}{*}{2014} & 130 & Marine & 800 & 20 & 1 & to 404 & 220 & 284 & 4.6 \\
\hline & & & 293 & Marine & 2230 & 20 & 1370 & to 1813 & 1592 & 1656 & 1.8 \\
\hline & \multirow[t]{2}{*}{${ }^{1} \mathrm{UNB} 14-07$} & \multirow[t]{2}{*}{2014} & 56 & Organic & 255 & 20 & 154 & to 421 & 299 & 363 & 1.5 \\
\hline & & & 150 & Marine & 825 & 20 & 1 & to 440 & 252 & 316 & 4.7 \\
\hline & \multirow[t]{2}{*}{ UNB14-08 } & \multirow[t]{2}{*}{2014} & 50 & Marine & -1075 & 20 & -8 & to -44 & -26 & 38 & 13.1 \\
\hline & & & 163 & Marine & 875 & 20 & 85 & to 488 & 312 & 376 & 4.3 \\
\hline \multirow[t]{9}{*}{ Tijuana } & TJE12-01 & 2012 & 144 & Organic & 560 & 15 & 533 & to 630 & 555 & 617 & 2.3 \\
\hline & TJE12-03 & 2012 & 54 & Organic & -980 & 50 & -8 & to $\quad-46$ & -27 & 35 & 14.6 \\
\hline & ${ }^{1}$ TJE12-04 & 2012 & 54 & Organic & -3000 & 90 & -13 & to $\quad-25$ & -19 & 43 & 12.5 \\
\hline & ${ }^{1}$ TJE12-04 & & 74 & Organic & -530 & 30 & -7 & to $\quad-60$ & -33 & 29 & 24.2 \\
\hline & \multirow[t]{2}{*}{${ }^{1}$ TJE12-06 } & \multirow[t]{2}{*}{2012} & 47 & Organic & 2320 & 40 & 2163 & to 2459 & 2340 & 2402 & 0.2 \\
\hline & & & 97 & Bulk & 2070 & 45 & 1905 & to 2149 & 2040 & 2102 & 0.5 \\
\hline & \multirow[t]{2}{*}{ TJE12-07 } & \multirow[t]{2}{*}{2012} & 65 & Marine & 550 & 20 & 114 & to 265 & 193 & 255 & 2.5 \\
\hline & & & 131 & Organic & 1575 & 20 & 1411 & to 1526 & 1468 & 1530 & 0.9 \\
\hline & TJE12-08 & 2012 & 142 & Organic & 1610 & 30 & 1413 & to 1557 & 1488 & 1550 & 0.9 \\
\hline
\end{tabular}

${ }^{1}$ Accretion rates inferred from post-1950 Common Era ${ }^{14} \mathrm{C}$ dates. 
Table 11. Mean long-term accretion rates calculated from radiocarbon, and short-term accretion rates calculated from radiocesium collection data for six study sites in California.

[Sites are ordered from north to south. ${ }^{14} \mathrm{C}$, carbon-14 (radiocarbon); ${ }^{137} \mathrm{Cs}$, cesium-13 (radiocesium); NA, not measured; $\pm \mathrm{SD}$, plus or minus standard deviation. $>$, greater than. $\mathrm{mm} / \mathrm{yr}$, millimeter per year]

\begin{tabular}{|c|c|c|c|c|c|c|}
\hline \multirow[b]{2}{*}{ Site } & \multirow[b]{2}{*}{$\begin{array}{l}\text { Number } \\
\text { of } \\
\text { samples }\end{array}$} & \multicolumn{3}{|c|}{ Long-term accretion (14C) } & \multicolumn{2}{|c|}{$\begin{array}{c}\text { Short-term accretion } \\
\text { (137Cs/post-bomb 14C) }\end{array}$} \\
\hline & & $\begin{array}{c}\text { Mean } \\
\text { time span } \\
\text { (years) }\end{array}$ & $\begin{array}{l}\text { Mean } \\
\text { accretion } \\
\text { rate } \\
(\mathrm{mm} / \mathrm{yr}) \\
\end{array}$ & $\begin{array}{c} \pm S D \\
(\mathrm{~mm} / \mathrm{yr})\end{array}$ & $\begin{array}{c}\text { Mean accretion } \\
\text { rate } \\
(\mathrm{mm} / \mathrm{yr})\end{array}$ & $\begin{array}{l}\text { Range } \\
\text { (mm/yr) }\end{array}$ \\
\hline Humboldt & 3 & 597 & 3.5 & 0.2 & ${ }^{1} 5.3$ & ${ }^{1} 4.9-5.7$ \\
\hline Bolinas & 3 & 1,193 & 3.0 & 2.8 & ${ }^{1} 21.2$ & NA \\
\hline Morro & 10 & 519 & 8.1 & 4.6 & 2.0 & NA \\
\hline Pt. Mugu & 3 & 43 & NA & NA & ${ }^{1} 14.4$ & ${ }^{1} 10.0-21.8$ \\
\hline Newport & 8 & 2,075 & 2.8 & 2.3 & 2.6 & NA \\
\hline Tijuana & 4 & 977 & 7.2 & 9.9 & $>4.1 ;{ }^{2} 9.1$ & ${ }^{2} 2.1-12.3$ \\
\hline
\end{tabular}

${ }^{1}$ Accretion rates inferred from post-1950 Common Era ${ }^{14} \mathrm{C}$ dates.

${ }^{2}$ Data from Weis and others (2001).

\section{Long-Term Accretion Relative to Sea-Level Rise}

Sediment accretion rates in California coastal marshes generally have kept pace with, or have exceeded, rates of SLR over the last 1,000-5,000 years according to the SLR estimates of 0.06-2.1 $\mathrm{mm} / \mathrm{yr}$ cited by Kemp and others (2011). We compared our site-specific estimates of mean long term accretion rates with estimated past and future SLR projections by the IPPC-AR5 and the National Research Council (2012) (fig. 23). Although historical rates of sedimentation cannot be used to predict future accretion (Kirwan and Mudd, 2012), our results indicate close agreement between rates of accretion in southern California marshes and past rates of SLR. 


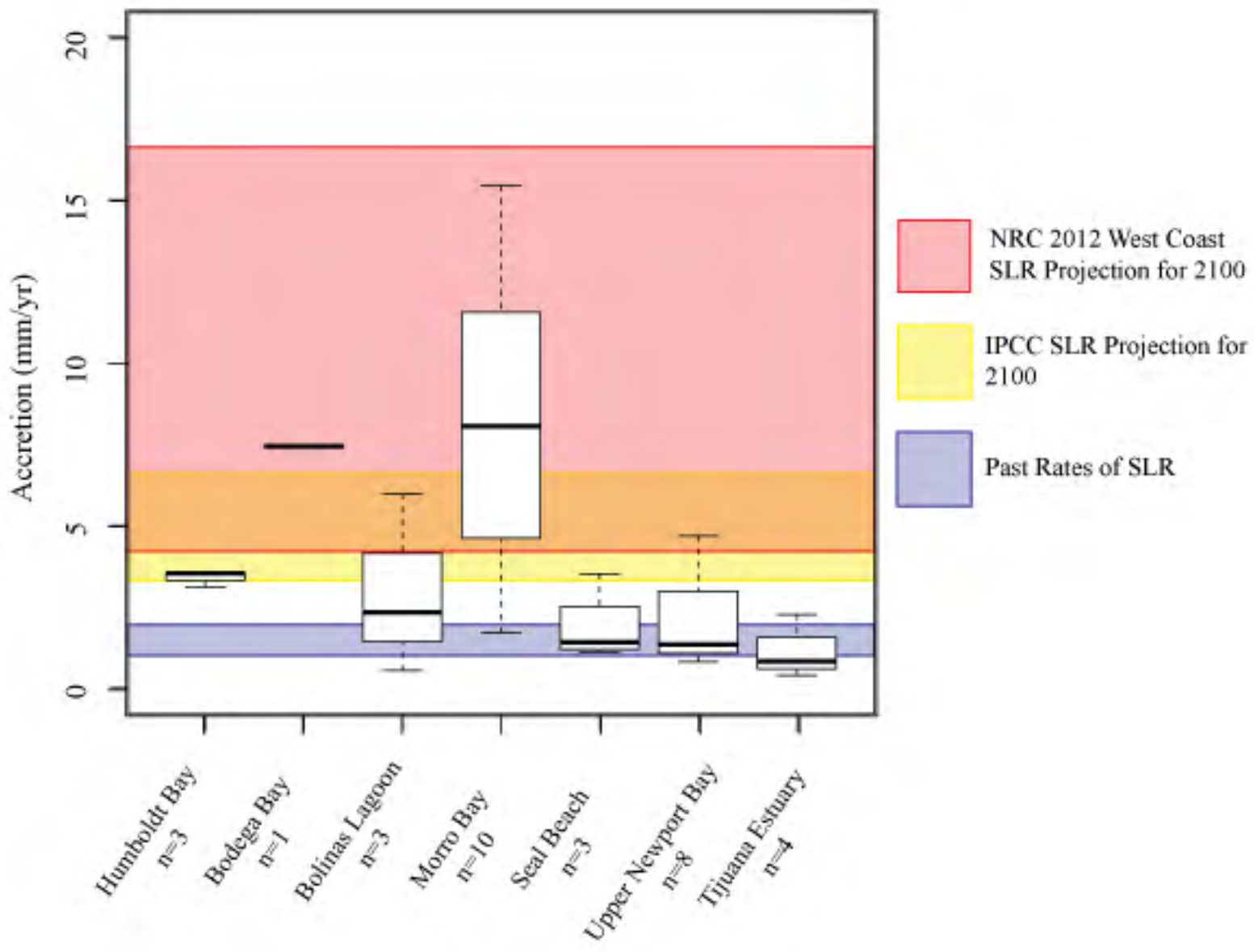

Figure 23. Boxplot showing site-specific ranges of long-term accretion rates compared with past and projected rates of sea-level rise (SLR) at seven California study sites. Accretion rates were obtained using the lowest radiocarbon age (non-enriched with modern carbon) and the date on which the core was collected (with $n$ showing number of cores per site). 


\subsection{Marsh Elevation Change Monitoring}

We installed Surface Elevation Tables (SETs) at our seven study sites between September and December $2013(n=24)$ to evaluate present-day changes in marsh surface elevation. As of June 2014, we have collected two to seven baseline readings at each site (fig. 24; table 12). Early results suggested that the magnitude of change in marsh surface elevation varied within sites and between low and high tidal marsh. Cumulative change in marsh surface elevation was positive in both high and low marsh at Bolinas and Mad River sites. In contrast, surface elevation decreased in high marsh locations at Morro, Pt. Mugu, San Pablo, and Tijuana sites. These initial findings should be considered inconclusive until several additional years of data have been collected.

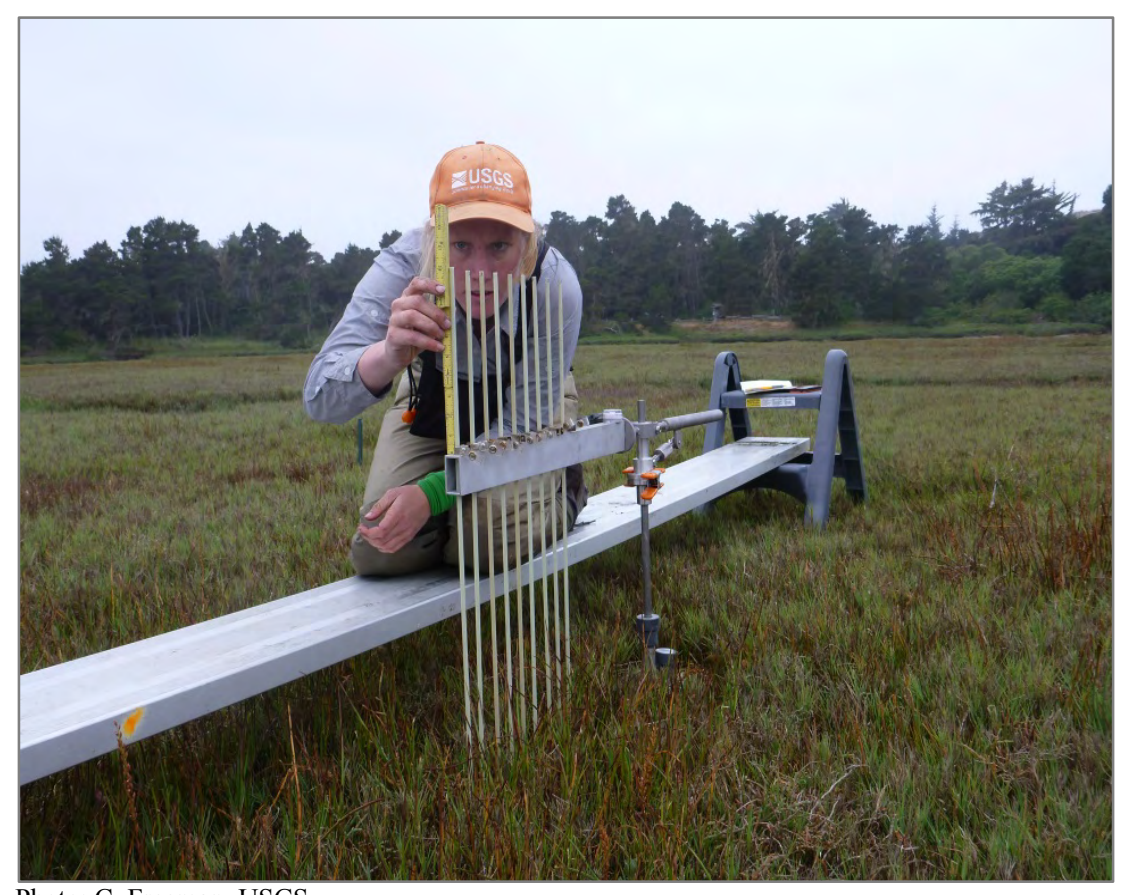

Photo: C. Freeman, USGS

Figure 24. U.S. Geological Survey technician measuring surface elevation change at a Surface Elevation Table, Mad River, Humboldt Bay, northern California. 
Table 12. Average cumulative net change in marsh surface elevation at Surface Elevation Table locations in California tidal marshes.

[All values are in centimeters. -, baseline reading]

\begin{tabular}{|c|c|c|c|c|c|c|c|c|c|}
\hline \multirow[b]{2}{*}{ Site } & \multirow[b]{2}{*}{$\begin{array}{l}\text { Sampling } \\
\text { date }\end{array}$} & \multicolumn{4}{|c|}{ Low marsh locations (number $=2$ ) } & \multicolumn{4}{|c|}{ High marsh locations (number $=2$ ) } \\
\hline & & $\begin{array}{c}\text { Cumulative } \\
\text { change }\end{array}$ & $\begin{array}{c}\text { Standard } \\
\text { Error }\end{array}$ & $\begin{array}{l}\text { Upper } \\
\text { bound }\end{array}$ & $\begin{array}{l}\text { Lower } \\
\text { bound }\end{array}$ & $\begin{array}{c}\text { Cumulative } \\
\text { change }\end{array}$ & $\begin{array}{c}\text { Standard } \\
\text { Error }\end{array}$ & $\begin{array}{l}\text { Upper } \\
\text { bound }\end{array}$ & $\begin{array}{l}\text { Lower } \\
\text { bound }\end{array}$ \\
\hline \multirow{4}{*}{$\begin{array}{l}\text { Mad } \\
\text { River }\end{array}$} & $06-20-13$ & - & - & - & - & - & - & - & - \\
\hline & $10-31-13$ & 1.84 & 0.87 & 2.71 & 0.97 & 0.89 & 0.33 & 1.22 & 0.56 \\
\hline & 01-09-14 & 2.64 & 0.19 & 2.83 & 2.45 & 1.42 & 0.3 & 1.71 & 1.12 \\
\hline & $06-04-14$ & 3.86 & 0.03 & 3.88 & 3.83 & 0.89 & 0.01 & 0.9 & 0.89 \\
\hline \multirow{5}{*}{$\begin{array}{l}\text { San } \\
\text { Pablo }\end{array}$} & $06-05-13$ & - & - & - & - & - & - & - & - \\
\hline & $09-26-13$ & -5.34 & 2.69 & -2.65 & -8.03 & 3.75 & 0.5 & 4.25 & 3.24 \\
\hline & $11-01-13$ & -8.44 & 1.56 & -6.88 & -10.01 & -0.83 & 0.71 & -0.12 & -1.53 \\
\hline & $02-05-14$ & -6.96 & 0.17 & -6.79 & -7.12 & 6.39 & 1.87 & 8.26 & 4.52 \\
\hline & $05-30-14$ & 0.38 & 0.64 & 1.03 & -0.26 & -8.8 & 2.6 & -6.2 & -11.39 \\
\hline \multirow[t]{5}{*}{ Bolinas } & $06-05-13$ & - & - & - & - & - & - & - & - \\
\hline & $07-22-13$ & 1.73 & 1.35 & 3.08 & 0.38 & 0.43 & 1.34 & 1.76 & -0.91 \\
\hline & $09-26-13$ & 7.5 & 1.58 & 9.08 & 5.92 & -0.07 & 0.13 & 0.06 & -0.2 \\
\hline & $12-17-13$ & 9.52 & 1.55 & 11.07 & 7.96 & 2.44 & 0.62 & 3.06 & 1.82 \\
\hline & $03-25-14$ & 9.86 & 0.34 & 10.2 & 9.52 & 0.95 & 1.6 & 2.55 & -0.65 \\
\hline \multirow[t]{4}{*}{ Morro } & $04-17-13$ & - & - & - & - & - & - & - & - \\
\hline & $09-10-13$ & 1.25 & 0.3 & 1.55 & 0.95 & -0.85 & 0.03 & -0.81 & -0.88 \\
\hline & $10-25-13$ & 3.48 & 1.25 & 4.73 & 2.23 & -0.73 & 0.14 & -0.59 & -0.86 \\
\hline & $01-21-14$ & 3.14 & 1.3 & 4.44 & 1.84 & -0.1 & 0.34 & 0.24 & -0.44 \\
\hline \multirow[t]{4}{*}{ Pt. Mugu } & $04-27-13$ & - & - & - & - & - & - & - & - \\
\hline & $08-15-13$ & -0.41 & 0.29 & -0.12 & -0.7 & -0.76 & 0.49 & -0.27 & -1.25 \\
\hline & $11-11-13$ & 1.05 & 0.68 & 1.74 & 0.37 & -0.72 & 0.41 & -0.31 & -1.13 \\
\hline & $02-14-14$ & 2.88 & 0.78 & 3.66 & 2.09 & 0.01 & 0.19 & 0.2 & -0.18 \\
\hline \multirow[t]{2}{*}{ Newport } & $12-6-13$ & - & - & - & - & - & - & - & - \\
\hline & $02-13-14$ & 1.59 & 0.59 & 2.18 & 1 & -1 & 0 & -1 & -1 \\
\hline \multirow[t]{7}{*}{ Tijuana } & 09-07-12 & - & - & - & - & - & - & - & - \\
\hline & $12-04-12$ & 2.75 & 0.28 & 3.03 & 2.47 & 2.44 & 0.34 & 2.78 & 2.1 \\
\hline & $03-11-13$ & 1.84 & 0.52 & 2.36 & 1.32 & 3.49 & 0.09 & 3.58 & 3.39 \\
\hline & $06-04-13$ & 1.68 & 1.6 & 3.28 & 0.07 & 1.45 & 0.15 & 1.6 & 1.3 \\
\hline & 09-06-13 & 1.52 & 0.32 & 1.83 & 1.2 & 0.71 & 0.44 & 1.15 & 0.27 \\
\hline & $12-04-13$ & 4.41 & 0.83 & 5.24 & 3.58 & 0.16 & 0.35 & 0.51 & -0.18 \\
\hline & $03-05-14$ & 5.54 & 0.57 & 6.1 & 4.97 & -0.2 & 0.29 & 0.08 & -0.49 \\
\hline
\end{tabular}




\subsection{Coastal Storm Modeling}

The Coastal Storm Modeling System (CoSMoS) is a multidimensional, deterministic modeling system that can scale down from global atmospheric forcing to local hazards assessments. Along the California coast, this modeling approach has been shown to adequately predict waves, water levels, coastal flooding, and coastal change over vast geographic regions with resolution and accuracy fine enough to aid local coastal management planning in real time or for future climate-induced changes impacts.

The El Niño-fueled storm of January 18-25, 2010, produced large waves (maximum deep water Hsig $=9 \mathrm{~m}$ ) that remained elevated for 1 week, producing some of the most extreme coastal erosion observed for several decades throughout California (Barnard and others, 2011). The recent timing of this event provided numerous observations both for model forcing and validation from a known severe storm and, thus, served as an optimal extreme storm test case for CoSMoS. In addition to running a hindcast of the January 2010 storm, the same storm-forcing conditions were combined with 2050 and 2100 SLR scenarios of +0.5 and $+1.4 \mathrm{~m}$ from Rahmstorf (2007). These water levels were added to the tidal forcing for the January 2010 storm to better understand the potential for increased flooding that could result from various SLR scenarios combined with a recent, well-documented coastal storm.

The accuracy of modeled wave heights and water levels was investigated in detail for the January 2010 storm and for a longer period (January and February 2011). A comparison of modeled and measured water level and nontidal residuals for the tide gauge on Scripps Pier in La Jolla, California, shows CoSMoS skill in predicting wave parameters, water levels, and surge for a large storm event (figs. 25-26). The timing of the storm peaks generally is captured well by the models throughout the hindcast period. 


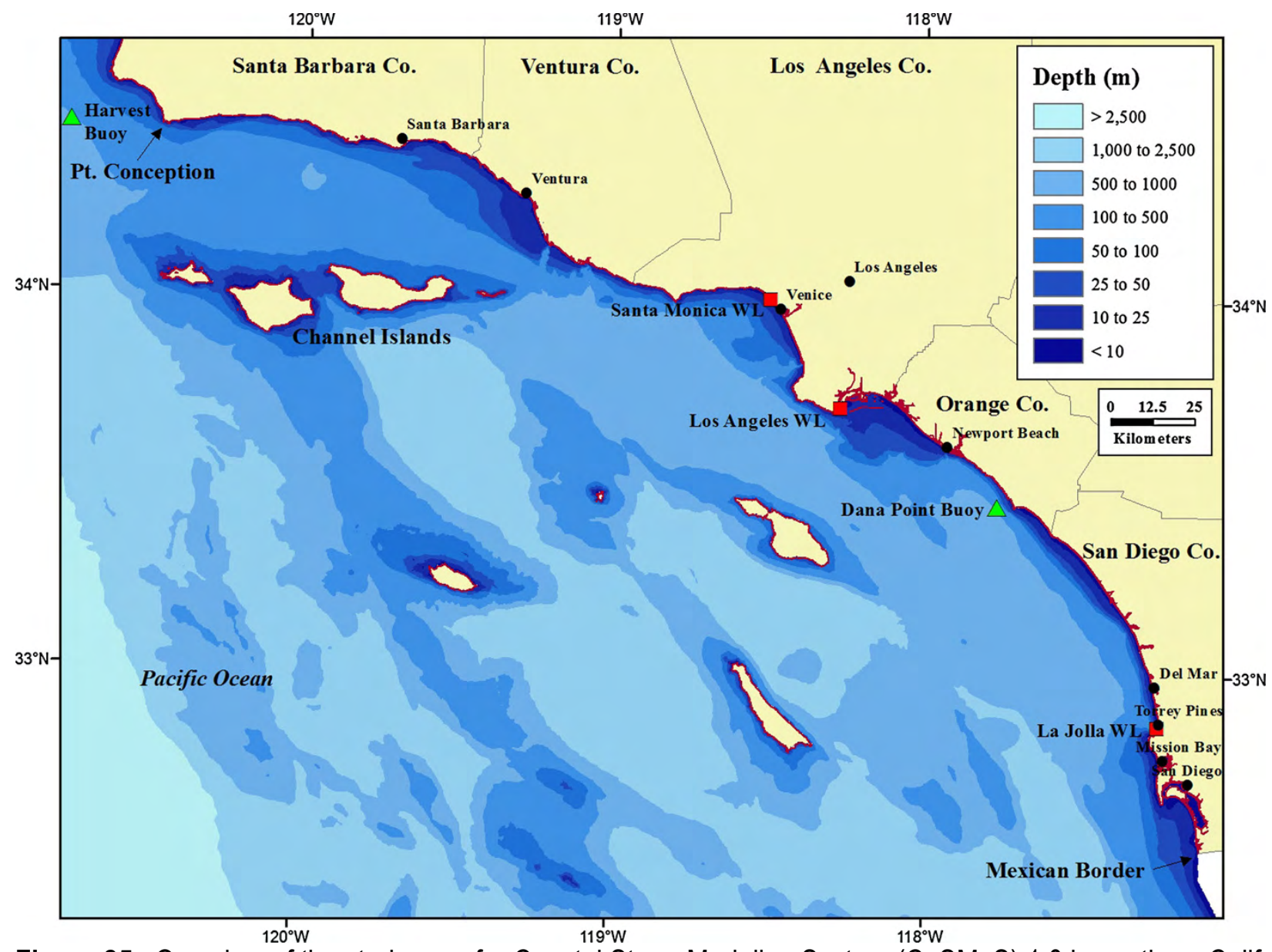

Figure 25. Overview of the study area for Coastal Storm Modeling System (CoSMoS) 1.0 in southern California, with locations of wave buoys (triangles) and water-level stations (squares) described in section 5.7,"Coastal Storm Modeling" (modified from Barnard and others, 2009). 


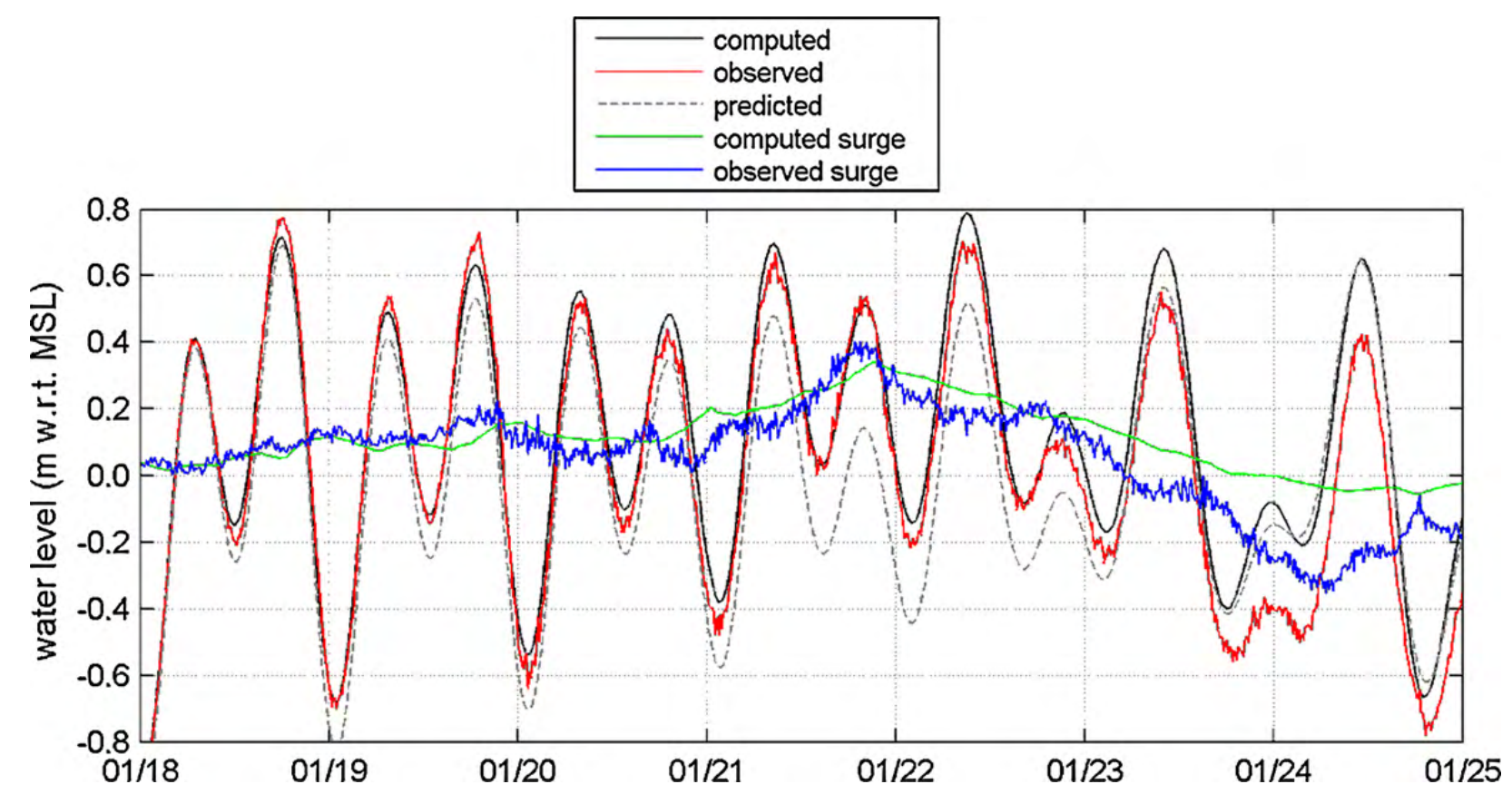

Figure 26. Nearshore water-level model-data from the water-level station for the storm hindcast (see fig. 25 for location), La Jolla, California, January 2010. Water-level data were obtained from National Oceanic and Atmospheric Administration (NOAA, 2013, modified from Barnard and others, 2009).

One of the difficulties in testing a coastal hazards model is a lack of validation information for the hazards themselves. Flood extents in particular are rarely measured except under the most extreme scenarios (for example, New Orleans following Hurricane Katrina). Although waves were not a significant factor, an extreme tide event coupled with an atmospheric low-pressure system caused significant flooding in Newport Harbor, on January 10, 2005. The tide was forecast to be $2.19 \mathrm{~m}$ above MLLW at 8:12 a.m. Local Standard Time at the NOAA Los Angeles tide gauge (National Oceanic and Atmospheric Administration, 2013). However, the actual tide measured $2.42 \mathrm{~m}, 0.22 \mathrm{~m}$ above forecast. Newport Beach officials extensively documented the flooding with photographs. Gallien and others $(2011,2012)$ georeferenced 85 photographs to delineate the flood extent in $\operatorname{ArcGIS}^{\mathrm{TM}}$. This represents the only known location and event where a coastal flooding event has been quantitatively determined along the entire United States West Coast. 
CoSMoS was run for this scenario, and the flood hazard map was overlaid with the groundtruthed flood determined from city photographs (fig. 27). By using wave run-up on the outer coast for a flood that primarily was confined to a protected embayment, CoSMoS conservatively overpredicted the flood extent, but there was a 52-percent overlap between CoSMoS predictions and what was measured on the ground, and the spatial coherence of the modeled and observed flood predictions is satisfactory. Gallien and others $(2011,2012)$ showed that local flood predictions improve by applying a hydrodynamic model to Newport Harbor and a highly refined local DEM that includes land-based realtime kinematic GPS surveys of important flood protection structures (for example, $15-\mathrm{cm}$ wide flood walls) that are not resolved by remotely sensed surveys (for example, lidar). Nevertheless, given the vast spatial scale CoSMoS covers, the accuracy of the projections for this small area is sufficient and accurate enough to suggest that the modeling system would support effective emergency response planning. In CoSMoS 2.0, all protected embayments are explicitly modeled with high-resolution nested grids to improve water-level predictions in these locations.

Perhaps the most useful examples of flooding extents predicted by CoSMoS are the progressive flooding caused by the hindcast of the January 2010 storm combined with the additional SLR scenarios of 0.5 and $1.4 \mathrm{~m}$. Over the vast expanse of southern California, this can clearly identify regions that are vulnerable to coastal flooding now or in the future, and broadly identify water elevation thresholds where SLR tips the balance of coastal vulnerability (fig. 27). At the local scale, as in the examples from Pt. Mugu, Newport, and Tijuana (fig. 27), in addition to the identification of SLR thresholds where flooding vulnerability might become extensive, the pathways for local flooding also can be clearly delineated to guide coastal management planning.

Although current limitations exist, $\mathrm{CoSMoS}$ can provide reasonably accurate projections to aid emergency response managers and coastal planners over large geographic regions in identifying local sites with notable storm and (or) SLR vulnerabilities. Despite a lack of available data and tools to address future impacts, consideration of climate change is increasingly becoming a requirement for any entity with coastal jurisdiction. 

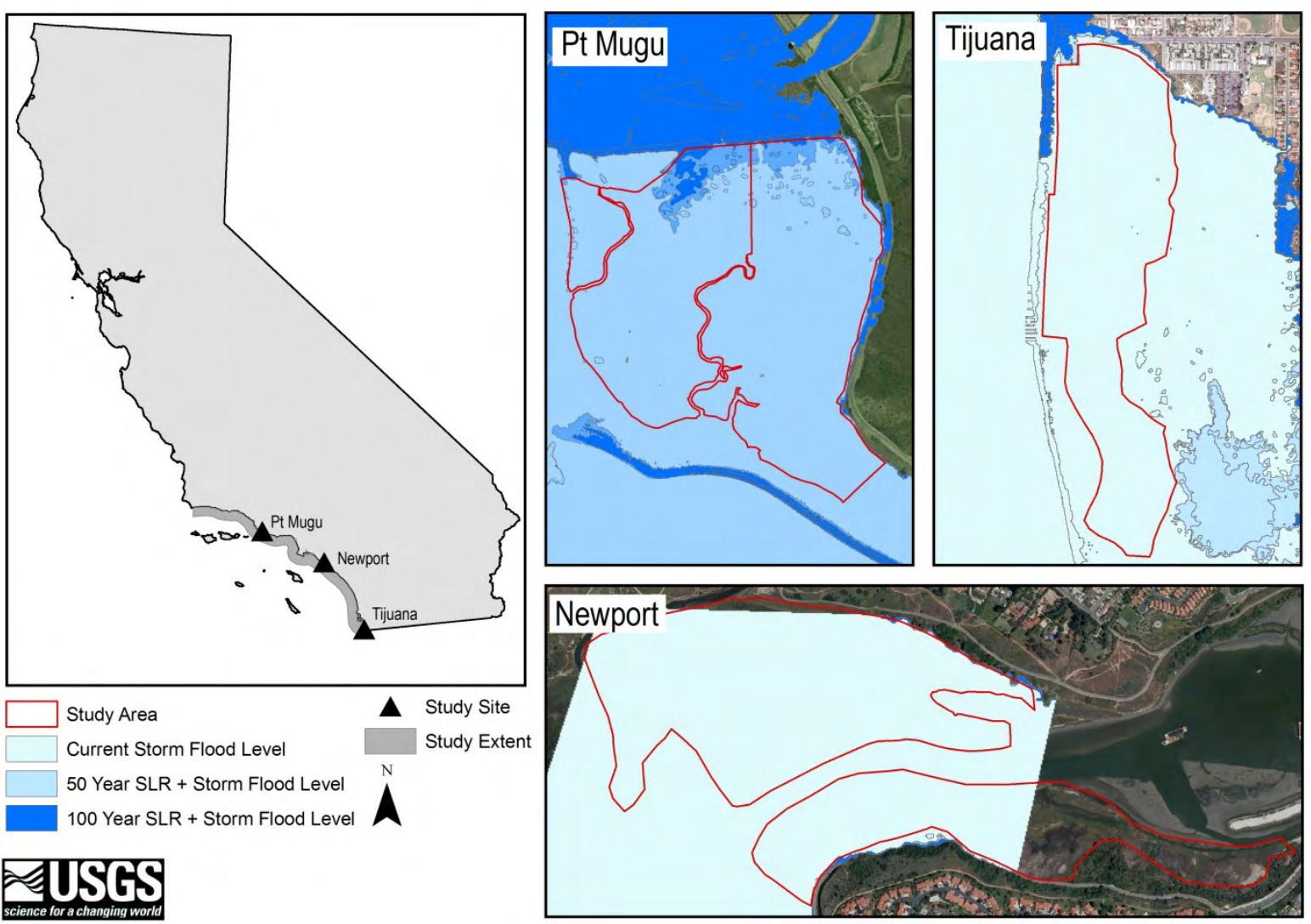

Figure 27. Flooding projected for three southern California study sites (Pt. Mugu, Newport, and Tijuana) for the January 2010 storm and the overlaid sea-level rise (SLR) scenarios. 


\subsection{Tidal Marsh Modeling Results}

We used National Research Council (2012) low, mid, and high SLR projections of $+44,+93$, and $+166 \mathrm{~cm}$, respectively, at all sites, except for Mad River where we used $+12,+63$, and $+142 \mathrm{~cm}$. Application of the WARMER model to our site-specific DEMs showed decreases in mean marsh elevation at all sites by the year 2110 under mid $(+63$ or $+93 \mathrm{~cm})$ and high SLR scenarios $(+166$ or +142 $\mathrm{cm}$ ) (fig. 28). However, most study sites had little or no loss of elevation relative to sea level under the low SLR projection $(+12$ or $+44 \mathrm{~cm})$ for most of the century. For example, at Mad River and Bolinas, the low SLR scenario had a small positive (or neutral) effect on mean marsh elevation over the coming century. Projected marsh elevation at Morro, Pt. Mugu, Newport, and Tijuana decreased under all SLR scenarios, but the timing of when that occurred differed depending on which SLR scenario was used. Under the NRC mid SLR scenario, elevation decreased at most study sites, but were projected to retain some low marsh habitat by the end of the century. Under the NRC high SLR scenario, all study sites were submerged by the end of the century (see appendixes $A-G$ for site-specific results). These sites were projected to shift from vegetated marsh to unvegetated mudflat and subtidal habitats.

We used consistently defined marsh elevation zones to compare projected SLR effects on tidal marsh habitat distribution among sites and across the coming century. In central and southern California, we found large shifts in habitat composition (figs. 29-30) and distribution (appendix figs. A13, A14, C12, C13, D13, D14, E13, E14, F12, F13, G13, G14) under mid and high SLR scenarios. For example, under mid SLR at Morro Bay, Newport and Tijuana, the current mixture of low, middle, and high marsh habitat is gradually replaced by low marsh around 2030-2050 and then by intertidal mudflat toward end of the century. At each of these sites, transitional marsh is essentially lost between 2050 and 2070, and high marsh remains present at the site only as a very small fraction of overall habitat composition before complete loss around 2090-2100. Under mid SLR, low marsh is projected to expand at all sites with a gradual decrease in high and middle marsh habitats by 2110 . Under mid and high SLR, mudflat is modeled to expand considerably at Morro Bay, Pt. Mugu, Newport, and Tijuana by 2110 . Only Mad River remained mostly vegetated by 2110 under the NRC mid SLR scenario.

All study sites were projected to be highly vulnerable under high SLR rates. Under the NRC high SLR scenario, Bolinas, Morro, Pt. Mugu, Newport, and Tijuana all undergo rapid loss of elevation and shifts in habitat zones around 2060-2080. Around 2080, Morro, Pt. Mugu, Newport, and Tijuana were all projected to transition to mudflat by the end of the century. More detailed results at each modeled site are presented in the appendixes.

We used a boosted regression tree (BRT) analysis to evaluate the relative contributions of different model factors to model outcomes (table 13). When SLR rate was included in the BRT analysis, it accounted for 85 percent of the variation in final elevation, which is not surprising considering the wide range of SLR rates tested in this study. Without SLR rate in the BRT analysis, initial elevation had the greatest relative impact (65.9 percent) on final elevation outputs in the modeling. Mineral and organic matter accumulation inputs accounted for a total of 23.3 percent of the variance, highlighting the importance of both internal and external sources of marsh accretion. Each of the other model parameters contributed less than 10 percent to the final variation in the results. The factors over which managers may have some control (initial elevation, and mineral and organic accumulation inputs) accounted for over one-half (89.2 percent) of the total variance. 
Sites

Bolinas Mad River Morro Mugu Newport Tijuana
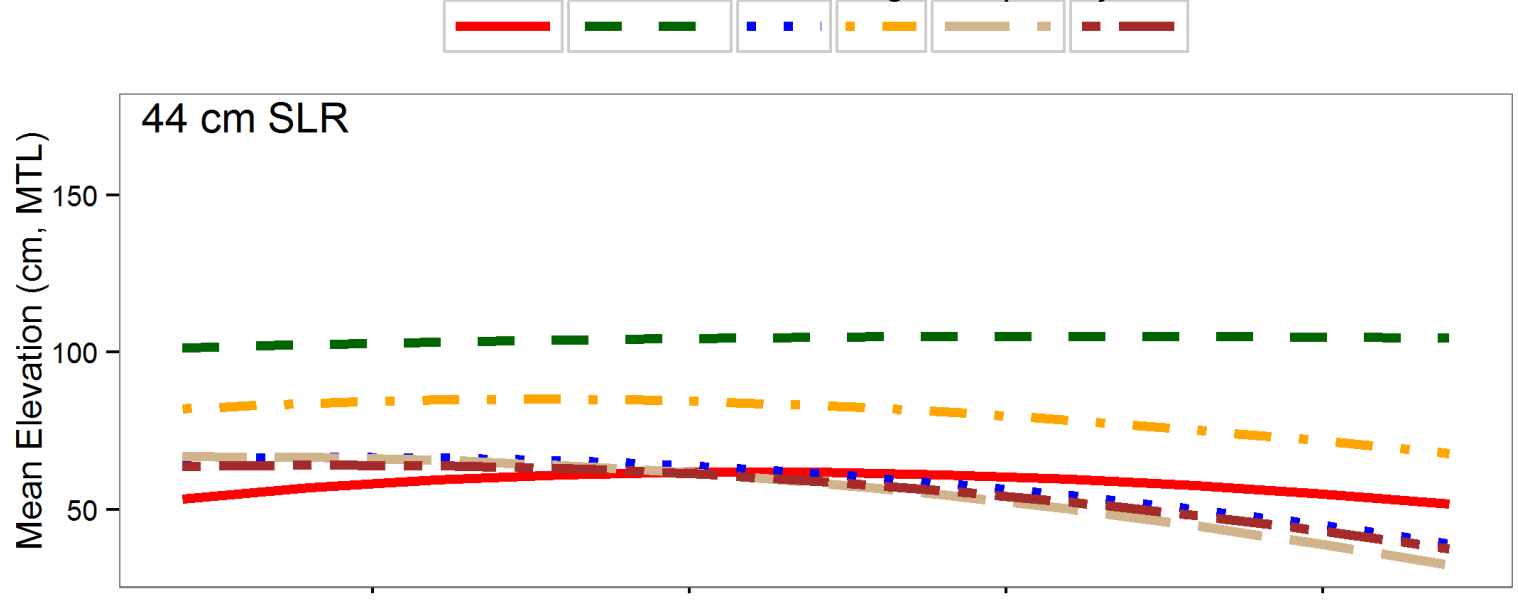

$93 \mathrm{~cm} \mathrm{SLR}$

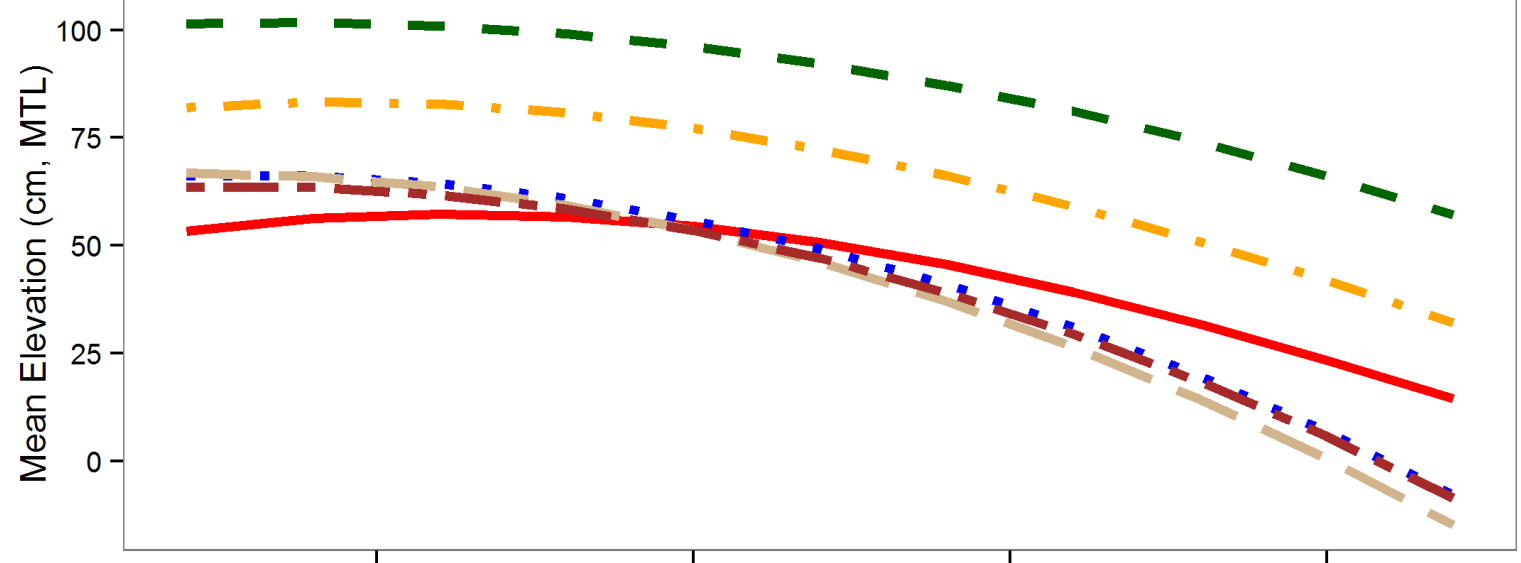

$166 \mathrm{~cm} \mathrm{SLR}$

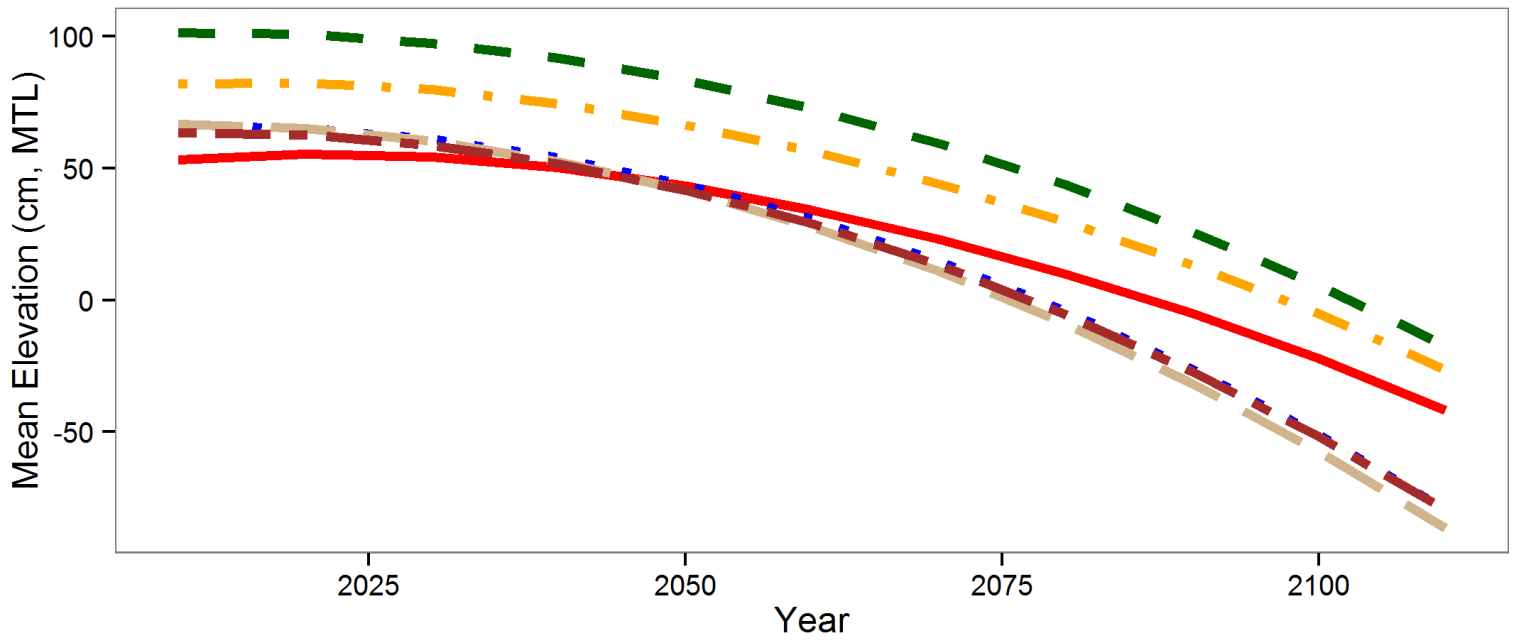

Figure 28. Projected changes in mean site elevation (centimeters relative to mean sea-level) for all California study sites using the WARMER model. Low, mid and high sea-level rise (SLR) scenarios are $+12,+63$, and +142 centimeters $(\mathrm{cm})$ at Mad River and $+44,+93$, and $+166 \mathrm{~cm}$ for all other sites by the year 2110 , respectively. 

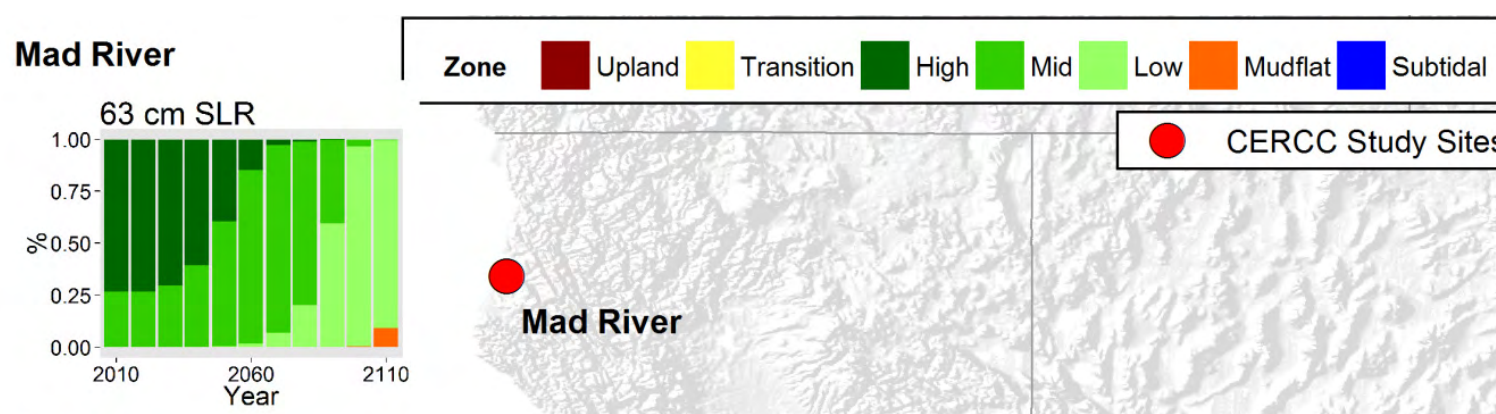

Bolinas
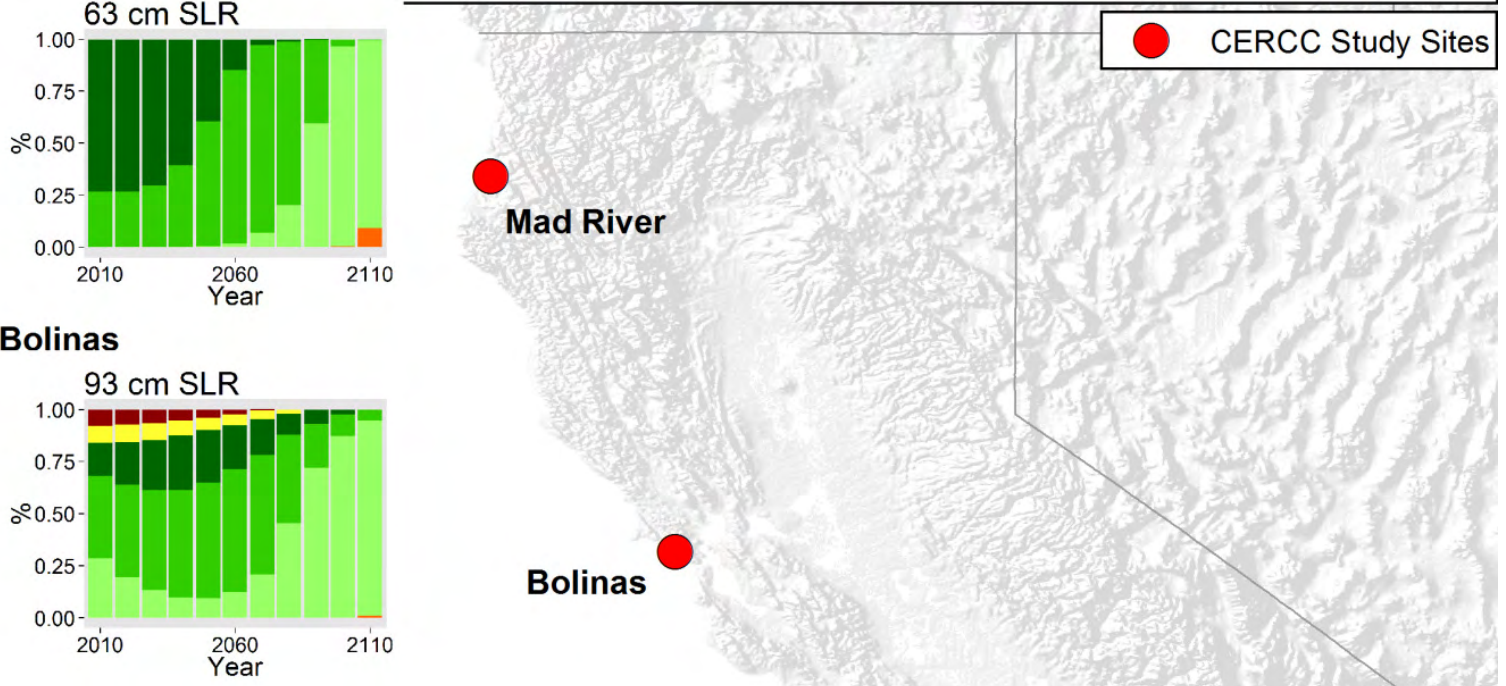

Mad River

Bolinas

\section{Morro}

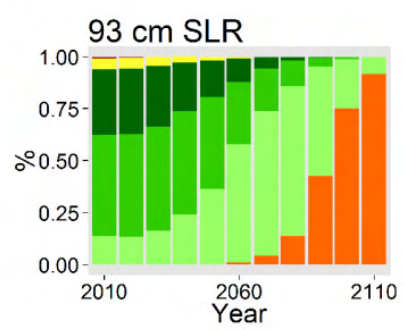

Pt. Mugu

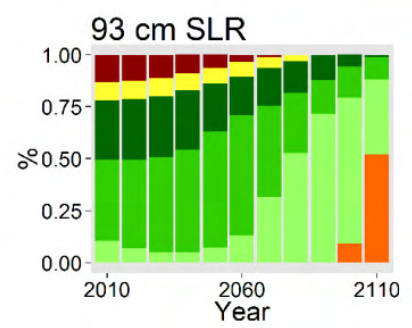

Newport

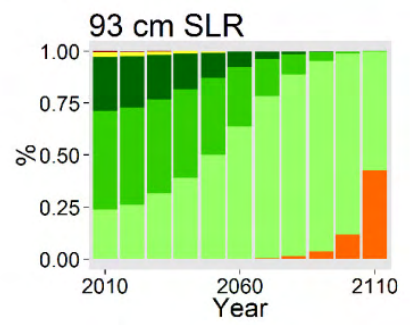

Tijuana

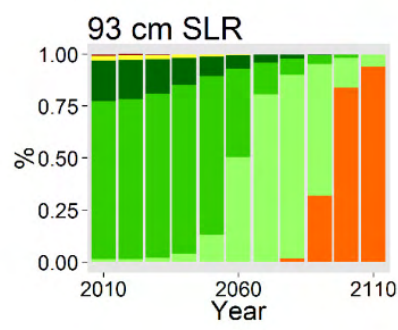

Figure 29. Projected changes in habitat composition under the National Research Council mid sea-level rise (SLR) scenario (63 centimeters [cm] for Mad River; $93 \mathrm{~cm}$ for all other California study sites), 2010-2110. CERCC, Coastal Ecosystem Response to Climate Change. 

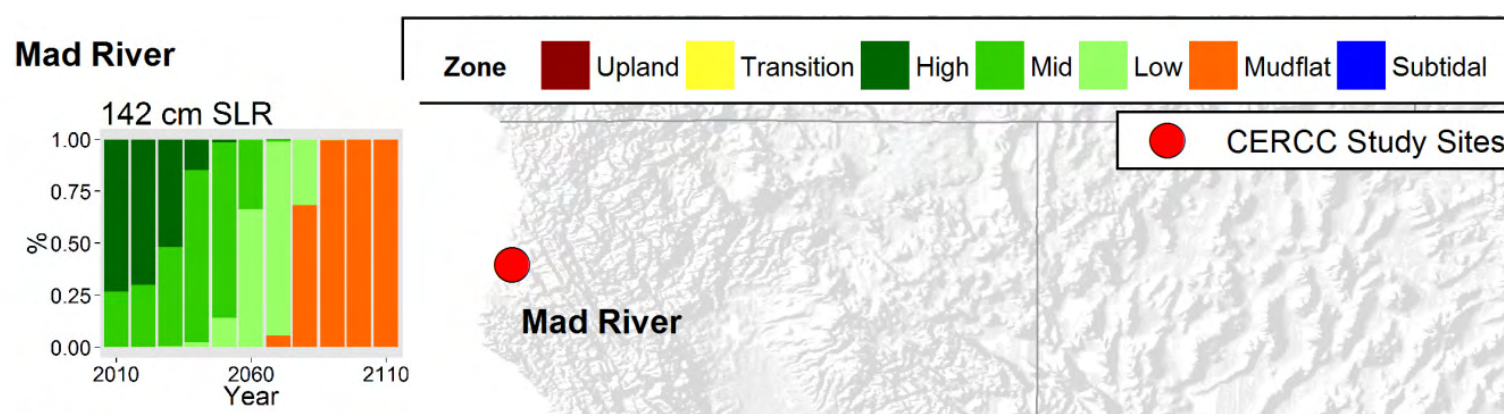

\section{Bolinas}
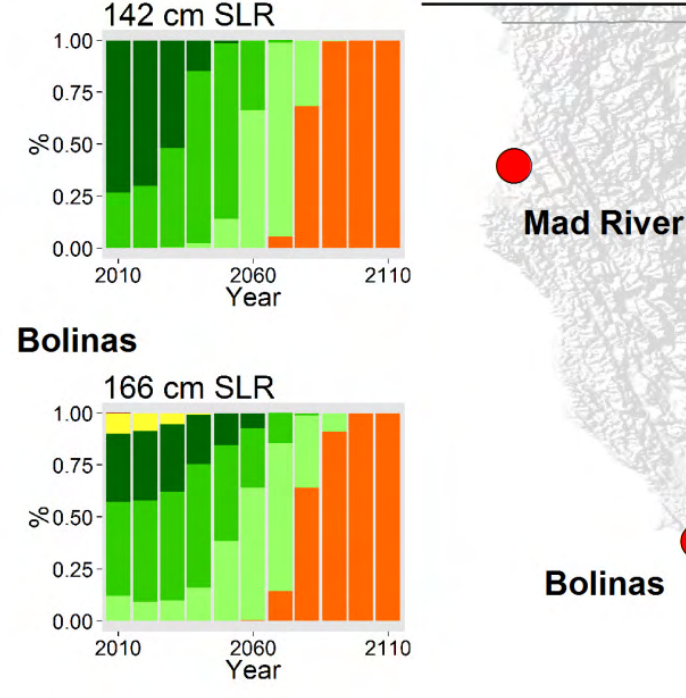

\section{Morro}

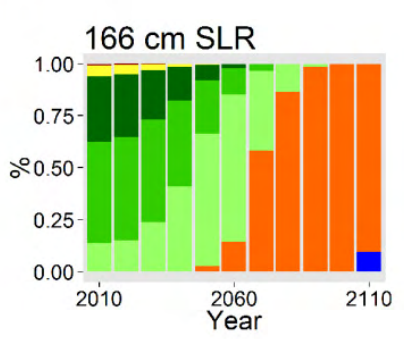

\section{Pt. Mugu}

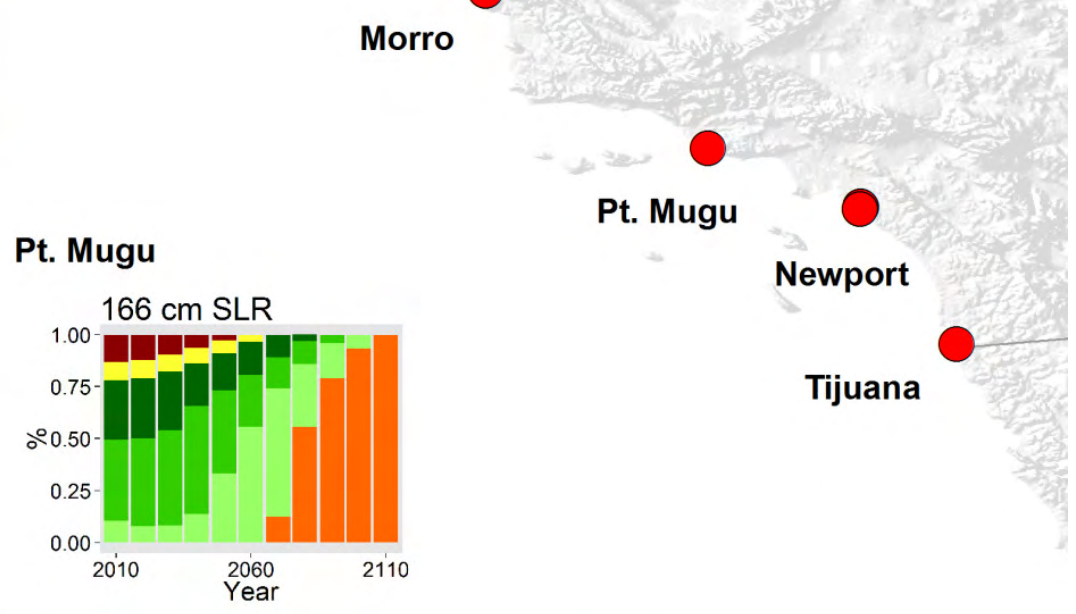

Pt. Mugu

CERCC Study Sites

Bolinas

\section{Newport}
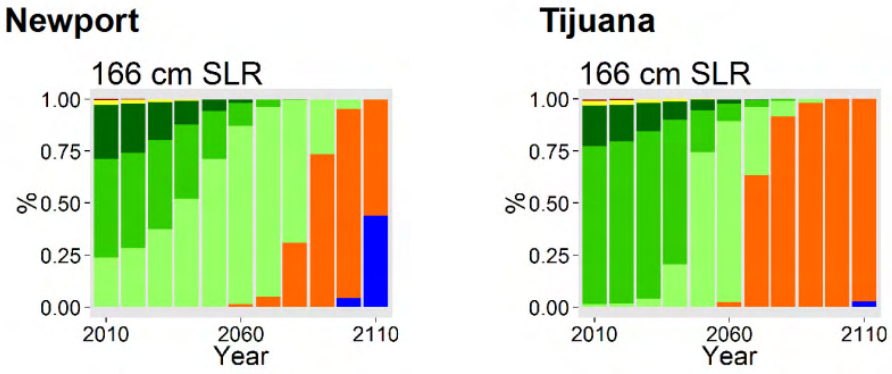

Figure 30. Projected changes in habitat composition under the National Research Council high sea-level rise (SLR) scenario (142 centimeters [cm] for Mad River; $166 \mathrm{~cm}$ for all other California study sites), 2010-2110. CERCC, Coastal Ecosystem Response to Climate Change. 
Table 13. Relative influence of key model parameters on final elevation in the WARMER modeling.

[Results at 2110 under the mid sea-level rise scenario were analyzed to determine the relative influence of model components on final elevations using a boosted regression tree analysis]

\begin{tabular}{lc}
\hline \multicolumn{1}{c}{ Independent variable } & $\begin{array}{c}\text { Relative Influence } \\
\text { (percentage) }\end{array}$ \\
\hline Initial elevation & 65.9 \\
Organic matter accumulation rate & 11.7 \\
Mineral accumulation rate & 11.6 \\
Tide range & 8.6 \\
Sediment refractory carbon & 1.8 \\
Sediment porosity & 0.4 \\
\hline
\end{tabular}




\section{Section 6-Analysis and Findings}

\section{Marsh Elevation, Accretion, and Modeling}

In this study, we combined intensive ground sampling with a mechanistic SLR model at a series of sites along the California coast to assess local and regional differences in tidal marsh vulnerability to SLR and storms. We documented site-specific differences in mean marsh elevation, vegetation composition and diversity, accretion rates, and water-level characteristics (tidal range and salinity). Using historical accretion data and monitoring of SETs, we determined that sites along the coast had variable historical accretion rates and that there were potential differences in present-day accretion between high and low marsh habitat.

We used the baseline data to parameterize the WARMER SLR model to evaluate potential changes in marsh elevation and habitat composition over the coming century using three major SLR projections for the West Coast of the United States from the National Research Council (2012). Our modeling results suggest that tidal marsh persistence at a range of sites spanning the California coast is threatened over the coming century, but that the timing and degree of projected impacts varies among locations and SLR scenarios. Under the NRC mid SLR scenario, sites in southern California (particularly Morro and Tijuana) tended to be the most vulnerable, losing most of their vegetated marsh habitat by 2110 . Sites in northern California also became relatively lower in elevation, tending to switch principally to low marsh habitat over the next 50-100 years. Our findings suggest that persistence of vegetated tidal marshes within existing marsh footprints is threatened if recent projections of coastal SLR are actualized over the coming century. However, more data are needed on these important ecosystems to fully determine their vulnerability to SLR, including understanding variation in sediment accretion within sites, variation in plant contributions to soil organic matter buildup, and how surrounding land-use practices may impede or facilitate migration of tidal wetlands in the future.

The highest rates of recent accretion were at Morro Bay $(>10 \mathrm{~mm} / \mathrm{yr})$, the only site where accretion exceeds recent SLR estimates by more than an order of magnitude. Morro also was the only site with accretion in the middle and upper elevations of the same marsh. These high rates may be caused, in part, by sediment inputs from the Chorro River delta system at the site. Deltaic marshes tend to have higher rates of sedimentation without significant elevation changes because of their higher energy, whereas back-barrier marshes (such as Newport) and estuaries (such as the north arm of Tijuana) have lower sedimentation and show good concordance between accretion and elevation change (Cahoon and others, 2006).

We sampled multiple sites in Morro with accretion rates from 10 to $20 \mathrm{~mm} / \mathrm{yr}$ (an order of magnitude higher than Tijuana, Newport, and past SLR rates). Because most of the radiocarbon dates from Morro are from the past 500 years, the higher rate of accretion there compared to other study sites may be a result of the different time period covered by the Morro sediment cores. However, accretion rates at the site also tended to vary by habitat type. Compared to other habitat types, high marsh at Morro had lower rates of accretion $(2.0 \pm 0.15 \mathrm{~mm} / \mathrm{yr})$ that are within the range of past SLR rates. Overall, the range of accretion rate estimates obtained in California marshes shows that sediment dynamics in these ecosystems may be highly temporal and spatial, even in periods of relatively stable sea levels. With accelerated SLR, marshes may face conditions in which the long-term average accretion rates will no longer be sufficient to mitigate habitat submergence. Potential acceleration in accretion rates observed in the recent past from the ${ }^{137} \mathrm{Cs}$ and post-bomb ${ }^{14} \mathrm{C}$ dating results suggest that wetlands have the capacity to accommodate accelerated SLR, but continued monitoring of coastal sedimentation is needed to assess resilience. 
Our present-day elevation surveys indicated that each marsh site had unique elevation profiles. Sites varied in mean elevation and the slope of elevation change (gradual compared to flat, bench-like marshes). For instance, Mad River was relatively higher than other sites in the local tidal frame. Tijuana occupied a narrower band of elevations, but at a lower elevation, below MHHW. Marsh habitat was more broadly distributed with elevation at sites such as Newport and Pt. Mugu where a range of elevations and thus habitat types, occurred.

Present-day elevation profiles and future SLR scenarios had the largest effects on WARMER model outcomes. Under a mid SLR scenario, however, most coastal marsh sites in this study were projected to decrease in mean elevation over the coming century. Because modeling outcomes appeared to be less affected by mineral sediment inputs or in situ productivity than by existing topography, internal processes in marshes may not be sufficient to help keep marsh accretion on par with local SLR. The paleo core data suggest that historical rates of accretion may meet or exceed present rates of SLR, but accelerated SLR over the coming century may eventually outpace marsh vertical growth.

Under the NRC high SLR scenario, the modeling results show high vulnerability of California marshes to habitat loss. Mean elevation at all sites was projected to decrease more than $100 \mathrm{~cm}$ between present day conditions and 2110. At most sites, projected mean elevation was well below MSL by 2110 , an elevation that generally only supports mudflat or Spartina foliosa-dominated marsh at selected sites in California.

\section{Marsh Vegetation}

Tidal marshes on the outer coast of California are dominated by perennial pickleweed, Sarcocornia pacifica, a highly salt-tolerant species (Pennings and Callaway, 1992; Ryan and Boyer, 2012). This species occurred across most elevation zones at most of the sites in the study, implying that it has some tolerance of variation in flooding as well. Sarcocornia occurs in California marshes as both as a monoculture and in combination with other subdominant species such as Jaumea and Frankenia. In addition to pickleweed, approximately a half dozen species were present in the California tidal marsh flora as subdominants. Most of these species - Distichlis spicata, Jaumea carnosa, and Frankenia salina-co-occur with Sarcocornia.

Zonation of vascular plant species is a feature of many California marshes (for example, Zedler, 1977). Typical high marsh species in California include Frankenia salina, Distichlis littoralis, Baccharis pilularis and Arthrocnemum subterminale. At certain sites, Spartina foliosa can be a dominant species forming monocultures in low marsh habitat. However, in some California marshes, pickleweed dominates the entire vertical gradient of salt marsh, so plant zonation may only be evident only as differences in the elevation distribution of subdominant or rarer species. Like previous studies, our research shows relatively broad overlap of species across the flooding (elevation) continuum (Vogl, 1966; Zedler, 1977). Species zonation seemed to be least pronounced at Mad River where 10 common species co-occurred in a relatively narrow elevation band within the high marsh zone. Vegetation patterns at Mad River may be due in part to recovery of the flora after recent disturbance of the site because Spartina densiflora removal was a recent (and ongoing) effort in Humboldt Bay marshes (Pickart, 2012).

Our modeling results suggested significant changes in the relative abundance of different marsh habitat zones at mid and high rates of SLR over the coming century. Many high and middle marsh areas are projected to become low marsh habitat given model assumptions about in situ productivity and accretion. Based on our understanding of the current distributions of tidal marsh plants in California, conversion of middle or high marsh areas to low marsh areas is expected to result in some expansion of Spartina foliosa habitat. Other areas may remain dominated by Sarcocornia pacifica because it frequently occurs across a wide range of elevations. Jaumea and Batis also may persist in these wetlands. 
Loss of high marsh and transitional habitat may threaten the persistence of species such as Distichlis littoralis, Arthrocnemum subterminale and Frankenia salina, which tend to occur only at higher elevations in California marshes. These species are more likely to remain present in the California tidal marsh flora, however, if there is room for lateral migration of high and transitional marshes onto upland habitat over the coming decades (for example, Schile and others, 2014). Without room for wetland movement (for example, restricted movement due to human development of upland), our modeling results suggest that there will be much less habitat available for high marsh species over the coming 50-100 years. Because middle and higher marsh zones generally tend to host the greatest plant diversity (for example, Onuf, 1987), this phenomenon of "coastal squeeze" (Torio and Chmura, 2013) and submergence is likely to reduce overall plant diversity in California's tidal marshes.

In addition to elevation, other factors including soil salinity, soil drainage, and species interactions are known to impact plant distribution in tidal marshes along the West Coast of North America (Pennings and Callaway 1992; Morzaria-Luna and others, 2004; Watson and Byrne, 2009; Janousek and Folger, 2014). Climate-driven changes to such gradients and processes also may affect the future distribution of tidal marsh plants within and among sites in California. For instance, increased evapotranspiration due to elevated coastal temperatures may increase soil salinity, affecting plant composition and productivity. Callaway and Sabraw (1994) noted that variation in freshwater input had effects on species composition and productivity at Carpinteria marsh in southern California.

\section{Future Marsh Function}

Our results suggest that California marshes may undergo large changes in habitat composition with moderate to high projections of SLR over the coming century. More wetland habitat may persist as tidal marsh (albeit usually as low marsh) if low rates of SLR are realized. Regardless of the magnitude of future SLR, we expect that changes in marsh structure also will lead to effects on the ecosystem processes and services supported by tidal marshes. For instance, studies conducted along the West Coast of the United States and elsewhere suggest that greater periods of tidal inundation leading to prolonged soil saturation may have negative effects on the productivity of future vegetation (Mahall and Park, 1976; Schile and others, 2011; Kirwan and Guntenspergen, 2012; Janousek and Mayo, 2013). Reduced plant productivity may decrease the habitat value of future marshes for species dependent on marshbased food webs or it may affect the three-dimensional structure of vegetation for refuge by marshdependent wildlife.

\section{Local Mitigation}

As the sea level rises along the California coast in the coming decades, in situ processes of marsh production and mineral sedimentation may be insufficient to keep marsh vertical growth on par with local SLR at some sites. To promote habitat persistence (especially in high marshes and transitional habitat), it may be necessary to take one or more proactive management steps to ensure marsh persistence. For instance, protecting existing upland habitat adjacent to existing tidal marshes may ensure that high marsh habitat can persist locally (by enabling marsh migration), and also may reduce the threat of flooding damage to human infrastructure. Additional management actions such as sediment enhancement on existing marshes may be desirable in some instances. 


\section{Section 7-Conclusions and Recommendations}

In this study, we used intensive local sampling at a series of sites along the California coast to model local and regional differences in tidal marsh vulnerability to sea-level rise (SLR). We documented site-specific differences in elevation, vegetation composition, mineral and organic matter accretion, and water level and salinity. Using paleocore data, we determined that California tidal marshes have had variable historical accretion rates. Ongoing monitoring of Surface Elevation Tables suggests differences in contemporary accretion rates between high and low marsh zones, and will enable future quantification of site-specific differences in sediment input to tidal marshes. Integrating the elevation, vegetation, and accretion data into elevation modeling (WARMER) under the National Research Council (NRC) SLR scenarios, we determined that tidal marsh persistence is likely to vary between estuaries and between SLR scenarios.

Under low SLR rates, our modeling suggested that tidal marsh persisted at all sites, but mid and high SLR rates threatened the persistence of vegetated marsh at most locations over the coming century. The timing and degree of projected impacts varied among sites. Under mid SLR projections, all sites lost high marsh habitat by 2110 , and most sites became dominated by either low marsh or mudflat habitat. Under mid SLR scenarios, Morro and Tijuana in southern California were the most vulnerable areas in the study, with the majority of the marsh area converting to mudflat by 2100 . However, all other study sites also became relatively lower in elevation, tending to transition to low marsh habitat over the next 50-100 years.

Changes in tidal marsh habitat composition with SLR may affect a variety of wetland-dependent organisms. For instance, changes in relative elevation across these marshes are expected to result in changes in plant community composition because of existing patterns of plant zonation along inundation gradients. Loss of mid and high marsh habitat loss across the region could have negative effects on terrestrial wildlife (that is, Ridgway Rail [Railus longirostris obsoletus] Ridgeway, salt-marsh harvest mouse [Reithrodontomys raviventris], and Belding's Savanah Sparrow [Passerculus sandwichensis beldingi]) that use less frequently inundated tidal marsh for foraging and nesting. However, corresponding gains in low marsh and mudflat may increase habitat available for estuarine fish, shellfish, or shorebirds. 
Future sediment supply and marsh productivity are likely to be key determinants of future marsh persistence in California. At all study sites, the high SLR scenario resulted in eventual transition from tidal marsh to mudflat habitat, suggesting that historical rates of net accretion are less than what is needed to keep pace with increasing sea level. Our preliminary findings suggest that California tidal marsh persistence over the coming century is threatened if mid and high projections of coastal SLR are realized. However, more data are needed on these important ecosystems to fully determine their vulnerability to SLR, including understanding the degree to which accretion varies within estuaries, how inundation impacts productivity in dominant vegetation species, and how surrounding land use practices may impede or allow the migration of wetlands in the future.

As sea-level rises along the Pacific coast in the coming decades, existing rates of marsh accretion at some sites may be insufficient to keep pace with local SLR. Proactive management may help promote habitat persistence (especially in transitional, high, and middle marsh habitats). For instance, protecting and restoring habitat adjacent to existing tidal marshes may ensure that marshes are able to migrate to former upland areas. Management of watershed practices may help downstream marshes obtain adequate sediment supply.

This project was successful in evaluating SLR vulnerability across a range of California tidal marshes. Our results inform both local and regional perspectives on potential tidal marsh vulnerability to SLR. We successfully partnered with local and regional resource managers to help provide information relevant to their climate-change planning process. Recommended next steps for this research program include:

- Incorporating marsh migration processes in coastal modeling;

- Researching processes inherent in marsh accretion potential, including organic matter contributions to soils and suspended sediment availability;

- Understanding changes in marsh function due to SLR, including vegetation responses to inundation and wildlife use of marsh habitats;

- Assessing suspended sediment delivery to estuaries that vary in size, geographic location, and salinity regime;

- Understanding storm impacts on sediment delivery;

- Linking intertidal mudflat processes with tidal marsh accretion rates;

- Developing vulnerability assessments for key management resources; and

- Integrating site-specific results with landscape-scale SLR modeling to assess estuarywide impacts.

Success of a regional project such as the U.S. Geological Survey Coastal Ecosystem Response to Climate Change network requires local manager and stakeholder engagement. Tidal marsh SLR response results were translated into vegetation zones to make the information more accessible to managers and their decision making processes. This project was successful in modeling SLR impacts to existing tidal marshes; however, better integration of our results with data from adjacent habitats (for example, mudflats and upland areas) would broaden the scope of our efforts to the broader estuarine environment. 


\section{Section 8-Outreach}

Our results will be made available in final report form (for example, U.S. Geological Survey Open-File Report) to agencies considering climate-induced change impacts to coastal estuaries, such as the California Landscape Conservation Cooperatives (LCCs), the U.S. Fish and Wildlife Service (FWS) National Wildlife Refuges, the FWS Inventory and Monitoring Program, the National Oceanic and Atmospheric Administration National Estuarine Research Reserve, the California Department of Fish and Wildlife, California State Parks, the U.S. Navy, and other interested land managers. Our study also will be valuable to future wetland restoration planning efforts throughout California.

We hosted three science delivery workshops in California in the Southwest Climate Science Center (SWCSC) region that were funded by the North Pacific and California LCCs (table 11). The workshop objectives were to:

1. Disseminate site-specific baseline data and modeling results, reveal coast-wide trends, and identify data gaps;

2. Identify how local climate science results may be incorporated in habitat conservation, planning, and adaptation strategies; and

3. Develop a coast-wide climate-change science needs assessment to inform the California and North Pacific LCCs. A final report will be compiled and provided to the SWCSC and California Landscape Conservation Cooperative in fiscal year 2016.

Table 14. Three California workshops to disseminate site-specific sea-level rise modeling results were hosted by the U.S. Geological Survey to engage resource managers and their partners.

\begin{tabular}{cclc}
\hline Site & Dates & $\begin{array}{c}\text { Workshop } \\
\text { location }\end{array}$ & $\begin{array}{c}\text { Number of } \\
\text { participants }\end{array}$ \\
\hline $\begin{array}{c}\text { San Pablo Bay National } \\
\text { Wildlife Refuge }\end{array}$ & $09-25-14$ & Petaluma & 15 \\
$\begin{array}{c}\text { Humboldt Bay - Mad } \\
\text { River }\end{array}$ & $10-02-10-03-14$ & Eureka & 44 \\
$\begin{array}{c}\text { San Diego Bay - } \\
\text { Tijuana River }\end{array}$ & $12-15-14$ & $\begin{array}{c}\text { Imperial } \\
\text { Beach }\end{array}$ & 26 \\
\hline
\end{tabular}

\section{Acknowledgments}

We thank the USGS DOI on the Landscape, California and North Pacific Landscape Conservation Cooperatives, and the Northwest and Southwest Climate Science Centers for support. We would like to thank the resource management staff of numerous agencies for providing assistance and site access, including Eric Nelson (USFWS), Kenneth Griggs (USFWS), Bill Carmen (Marin County Parks), Adrienne Harris (Morro Bay National Estuary Program [MBNEP]), Ann Kitajima (MBNEP), Martin Ruane (Naval Base Ventura County [NBVC]), Carla Navarro (CDFW), Brian Collins (USFWS), Jeff Crooks (Tijuana River NERR), Don Brubaker (USFWS), Meg Marriott (USGWS), Anne Morkill (USFWS), and Andy Yuen (USFWS). Additionally, we thank Ari Goodman, Pia Gabriel, Justin McCullough, Laura Hollander, Laurel Ann Curry, Tristan Edgarian, Marcus Thompson, Katherine Lovett, and Scott Lydon, who assisted with data collection or analyses. We also thank Kathryn Hargan and John Smol from Queen's University, and Alexander Simms, Laura Reynolds, and John Southon for sediment core dating. 


\section{References Cited}

Baldwin, B.G., Goldman, D.H., Keil, D.J., Patterson, R., Rosatti, T.J., and Wilken, D.H., 2012, The Jepson manual-Vascular plants of California (2d ed.): Berkeley, University of California Press, $1,600 \mathrm{p}$.

Barnard, P.L., O'Reilly, Bill, van Ormondt, Maarten, Elias, Edwin, Ruggiero, Peter, Erikson, L.H., Hapke, Cheryl, Collins, B.D., Guza, R.T., Adams, P.N., and Thomas, J.T., 2009, The framework of a coastal hazards model; a tool for predicting the impact of severe storms: U.S. Geological Survey Open-File Report 2009-1073, 21 p. [http://pubs.usgs.gov/of/2009/1073/].

Barnard, P.L., van Ormondt, M., Erikson, L.H., Eshleman, J., Hapke, C., Ruggiero, P., Adams, P.N., and Foxgrover, A.C., 2014, Development of the Coastal Storm Modeling System (CoSMoS) for predicting the impact of storms on high-energy, active-margin coasts: Natural Hazards, v. 74, no. 2 , p.1-31, doi:10.1007/s11069-014-1236-y.

Brand, L.A., Smith, L.M., Takekawa, J.Y., Athearn, N.D., Taylor, K., Shellenbarger, G.G., Schoellhamer, D.H., and Spenst, R., 2012, Trajectory of early tidal marsh restoration- Elevation, sedimentation and colonization of breached salt marsh ponds in the northern San Francisco Bay: Ecological Engineering, v. 42, p. 19-29.

Cahoon, D.R., Hensel, P.F., Spencer, T., Reed, D.J., Mckee, K.L., and Saintilan, N., 2006, Coastal wetland vulnerability to relative sea-level rise-Wetland elevation trends and process controls: Ecological Studies, v. 190, p, 271-292.

Cahoon, D.R., Lynch, J.C., Hensel, P., Boumans, R., Perez, B.C., Segura, B., and Day, J.W., 2002, High precision measurements of wetland sediment elevation-I, recent improvements to the sedimentationerosion table: Journal of Sedimentary Research, v. 72, p. 730-733.

California Natural Resources Agency, 2010, California climate adaptation strategy-2010 progress report: Report to the Governor of California, 9 p.

Callaway, J.C., Borgnis, E.L., Turner, R.E., and Milan, C.S., 2012, Carbon sequestration and sediment accretion in San Francisco Bay tidal wetlands: Estuaries and Coasts, v. 35, p. 1,163-1,181, doi: 10.1007/s12237-012-9508-9.

Callaway, J.C., Delaune, R.D., and Patrick, W.H., 1996, Chernobyl 137Cs used to determine sediment accretion rates at selected northern European coastal wetlands: Limnology and Oceanography, v. 41, p. 444-450.

Callaway, R.M., and Sabraw, C.S., 1994, Effects of variable precipitation on the structure and diversity of a California salt marsh community: Journal of Vegetation Science, v. 5, p. 433-438, doi: $10.2307 / 3235867$.

Deverel, S.J., Drexler, J.Z., Ingrum, T., and Hart, C., 2008, Simulated Holocene, recent, and future accretion in channel marsh islands and impounded marshes for subsidence mitigation, SacramentoSan Joaquin Delta, California, USA: REPEAT Project Final Report to the CALFED Science Program of the Resources Agency of California, $60 \mathrm{p}$.

Gallien, T.W., Schubert, J.E., and Sanders, B.F., 2011, Predicting tidal flooding of urbanized embayments - a modeling framework and data requirements: Coast Engineering, v. 58, p.567-577.

Gallien, T.W., Barnard, P.L., van Ormondt, M., Foxgrover, A.C., and Sanders, B.F., 2012, A parcelscale coastal flood forecasting prototype for a Southern California urbanized embayment: Journal of Coastal Research, v. 29, no. 3, p. 642-656, doi:10.2112/JCOASTRES-D-12-00114.1.

Gedan, K.B., Silliman, B.R., and Bertness, M.D., 2009, Centuries of human-driven change in salt marsh ecosystems: Annual Review of Marine Science, v. 1, p. 117-141, doi:

10.1146/annurev.marine.010908.163930. 
Gent, P.R., Danabasoglu, G., Donner, L.J., Holland, M.M., Hunke, E.C., Jayne, S.R., Lawrence, D.M., Neale, R.B., Rasch, P.J., Vertenstein, M., Worley, P.H., Yang, Z.-L., and Zhang, M., 2011, The community climate system model version 4: Journal of Climate, v. 24, p. 4,973-4,991, doi: 10.1175/2011JCLI4083.1.

Heiri, O., Lotter, A.F., and Lemcke, G., 2001, Loss on ignition as a method for estimating organic and carbonate content in sediments - Reproducibility and comparability of results: Journal of Paleolimnology, v. 25, p. 101-110.

Huppert, D.D., Moore, A., and Dyson, K., 2009, Impacts of climate change on the coasts of Washington State, chap. 8 of Littell, J.S., Elsner, M. McGuire, Binder, L.C. Whitely, and Snover, A.K., eds., The Washington climate change impacts assessment-Evaluating Washington's future in a changing climate: Seattle, University of Washington, Climate Impacts Group, p. 285-309, , http://cses.washington.edu/cig/outreach/waccia/.

Intergovernmental Panel on Climate Change, 2014, Summary for policymakers, in Field, C.B., Barros, V.R., Dokken, D.J., Mach, K.J., Mastrandrea, M.D., Billir, T.E., Chatterjee, M., Ebi, K.L., Estrada, Y.O., Genova, R.C., Girma, B., Kissel, E.S., Levy, A.N., MacCracken, S., Mastrandrea, P.R., and White, L.L. eds., Climate change 2014-Impacts, adaptation, and vulnerability, part A-Global and sectoral aspects, Contribution of working group II to the fifth assessment report of the Intergovernmental Panel on Climate Change Cambridge, United Kingdom, and New York, United States, Cambridge University Press, p. 1-32.

Janousek, C.N., Buffington, K.J., Thorne, K.J., Guntenspergen , G.R., Takekawa, J.Y., and Dugger, B.D., 2016, Potential effects of sea-level rise on plant productivity- species-specific responses in northeast Pacific tidal marshes: Marine Ecology, v. 548, p. 111-125, doi: 10.3354/meps11683.

Janousek, C.N., and Folger, C.L., 2014, Variation in tidal wetland plant diversity and composition within and among coastal estuaries-Assessing the relative importance of environmental gradients: Journal of Vegetation Scienc, v. 25, p. 534-545.

Janousek, C.N., and Mayo, C., 2013, Plant responses to increased inundation and salt exposureInteractive effects on tidal marsh productivity: Plant Ecology, v. 214, p. 917-928, doi: 10.1007/s11258-013-0218-6.

Kemp, A.C., Horton, B.P., Donnelly, J.P., Mann, M.E., Vermeer, M., and Rahmstorf, S., 2011, Climate related sea-level variations over the past two millennia: Proceedings of the National Academy of Sciences, v. 108, p. 11,017-11,022, doi: 10.1073/pnas.1015619108.

Kirwan, M.L., and Megonigal, J.P., 2013, Tidal wetland stability in the face of human impacts and sealevel rise: Nature, v. 504, p. 53-60, doi: 10.1038/nature12856.

Kirwan, M.L., and Mudd, S.M., 2012, Response of salt-marsh carbon accumulation to climate change: Nature, v. 489, p. 550-553, doi: 10.1038/nature11440.

Mahall, B.E., and Park, R.B., 1976, The ecotone between Spartina foliosa Trin. and Salicornia virginica L. in salt marshes of Northern San Francisco Bay: Journal of Ecology, v. 64, p. 793-809.

Morris, J.T., Sundareshwar, P.V., Nietch, C.T., Kjerfve, B., and Cahoon, D.R., 2002, Responses of coastal wetlands to rising sea level: Ecology, v. 83, p. 2,869-2,877.

Morzaria-Luna, H., Callaway, J.C., Sullivan, G., and Zedler, J.B., 2004, Relationship between topographic heterogeneity and vegetation patterns in a Californian salt marsh: Journal of Vegetation Science, v. 14, p. 523-530.

Moss, R., Babiker, M., Brinkman, S., Calvo, E., Carter, T., Edmonds, J., Elgizouli, I., Emori, S., Erda, L., Hibbard, K.A., et al, 2008. Towards new scenarios for analysis of emissions, climate change, impacts, and response strategies. Intergovernmental Panel on Climate Change, p. 132.

National Fish, Wildlife and Plants Climate Adaptation Partnership. 2012. National fish, wildlife and plants climate adaptation strategy: Association of Fish and Wildlife Agencies, Council on 
Environmental Quality, Great Lakes Indian Fish and Wildlife Commission, National Oceanic and Atmospheric Administration, and U.S. Fish and Wildlife Service, Washington, D.C.

National Oceanic and Atmospheric Administration, 2003, Computational techniques for tidal datums handbook: National Oceanic and Atmospheric Administration, Special Publication NOS CO-OPS 2, $98 \mathrm{p}$.

National Oceanic and Atmospheric Administration, National Centers for Environmental Information, State of the Climate - National Overview for Annual 2013, published online January 2014.

National Research Council, 2012, Sea-level rise for the coasts of California, Oregon, and Washington-

Past, present, and future: National Academy of Sciences, The National Academies Press, 201 p.

Onuf, C.P., 1987, The ecology of Mugu Lagoon, California-An estuarine profile: U.S. Fish and Wildlife Service Biological Report, v. 85, p. 122.

Pennings, S.C., and Callaway, R.M., 1992, Salt marsh plant zonation-The relative importance of competition and physical factors: Ecology, v. 73, p. 681-690.

Pickart, A.J., 2012, Spartina densiflora invasion ecology and the restoration of native salt marshes at Humboldt Bay National Wildlife Refuge: U.S. Fish and Wildlife Service Report, 54 p.

Rahmstorf, S., 2007, A semi-empirical approach to projecting future sea-level rise. Science, v. 315, p. 368-370.Reimer, P.J., Bard, E., Bayliss, A., Beck, J.W., Blackwell, P.G., Bronk Ramsey, C., Buck, C.E., Cheng, H., Edwards, R.L., Friedrich, M., Grootes, P.M., Guilderson, T.P., Haflidason, H., Hajdas, I., and others, 2013, Intcal13 and marine13 radiocarbon age calibration curves $0-50,000$ years cal bp: Radiocarbon, v. 55, p. 1,869-1,887.

Ryan, A.B., and Boyer, K.E., 2012, Nitrogen further promotes a dominant salt marsh plant in an increasingly saline environment: Journal of Plant Ecology, v. 5, p. 429-441, doi: 10.1093/jpe/rts001.

Santos, G.M., Moore, R.B., Southon, J.R., Griffin, S., Higner, E., and Zhang, D., 2007, AMC 14C sample preparation at the KCCAMS/UCI facility-Status report and performance of small samples: Radiocarbon, v. 49, p. 255-269.

Scavia, D., Field, J.C., Boesch, D.F., Buddemeier, R.W., Burkett, V., Cayan, D.R., Fogarty, M., Harwell, M.A., Howarth, R.W., Mason, C., Reed, D.J., Royer, T.C., Sallenger, A.H., and Titus, J.G., 2002, Climate change impacts on U.S. coastal and marine ecosystems: Estuaries, v. no. 25, p. 149164.

Schile, L.M., Callaway, J.C., Morris, J.T., Stralberg, D., Parker, V.T., and Kelly, M., 2014, Modeling tidal marsh distribution with sea-level rise - Evaluating the role of vegetation, sediment, and upland habitat in marsh resiliency: PloS One, http://dx.doi.org/10.1371/journal.pone.0088760.

Schile, L.M., Callaway, J.C., Parker, V.T., and Vasey, M.C., 2011, Salinity and inundation influence productivity of the halophytic plant Sarcocornia pacifica: Wetlands, v. 31, p. 1,165-1,174, doi: 10.1007/s13157-011-0227-y.

Seafloor Mapping Lab, 2013, Mugu Lagoon Survey-Multibeam bathymetry data and derived products, September 2012: California State University, Monterey Bay, http://seafloor.otterlabs.org/.

Skamarock, W.C., Klemp, J.B., Dudhia, J., Gill, D.O., and Barker, D.M., 2008, A description of the Advanced Research WRF version 3: National Center for Atmospheric Research Technical Note NCAR/TN-475+STR, 113 p.

Slangen, A.B.A., Carson, M., Katsman, C.A., van de Wal, R.S.W., Köhl, A., Vermeersen, L.L.A., and Stammer, D., 2014, Projecting twenty-first century regional sea-level changes: Climatic Change, v. 124, p. 317-332, doi: 10.1007/s10584-014-1080-9.

Swanson, K.M., Drexler, J.Z., Schoellhamer, D.H., Thorne, K.M., Casazza, M.L., Overton, C.T., Callaway, J.C., and Takekawa, J.Y., 2013, Wetland accretion rate model of ecosystem resilience (WARMER) and its application to habitat sustainability for endangered species in the San Francisco Estuary: Estuaries and Coasts, v. 37, p. 476-492, doi: 10.1007/s12237-013-9694-0. 
Takekawa, J.Y., Thorne, K.M., Buffington, K.J., Spragens, K., Swanson, K., Drexler, J., Schoellhamer, D., Overton, C.T., and Casazza. M.L., 2012, Final report for sea-level rise response modeling for San Francisco Bay estuary tidal marshes. U.S. Geological Survey Open-File Report 2012. Retrieved from: www.werc.usgs.gov/SFBaySLR.

Takekawa, J.Y., Woo, I., Athearn, N.D., Demers, S., Gardiner, R.J., Perry, W.M., Ganju, N.K., Shellenbarger, G.G., and Schoellhamer, D.H., 2010, Measuring sediment accretion in early tidal marsh restoration: Wetlands Ecology and Management, v. 18, p. 297-305.

Thompson, R., and Battarbee, R., 1975, Magnetic susceptibility of lake sediments: Limnology and Oceanography, v. 20, p. 687-698.

Thorne, K.M., Buffington, K.J., Elliott-Fisk, D.L., Takekawa, J.Y., 2015, Tidal marsh susceptibility to sea-level rise: importance of local-scale models. Journal of Fish and Wildlife Management, v. 6, no. 2 , p. 290-304; e1944-687X. doi: 10.3996/062014-JFWM-048

Torio, D.D., and Chmura, G.L., 2013, Assessing coastal squeeze of tidal wetlands: Journal of Coastal Research, v. 29, p. 1,049-1,061, doi: 10.2112/JCOASTRES-D-12-00162.1.

Tucker, C.J., 1979, Red and photographic infrared linear combinations for monitoring vegetation: Remote Sensing of Environment, v. 8, p. 127-150.

United Nations Educational, Scientific and Cultural Organization, 1983, Algorithms for computation of fundamental properties of seawater: United Nations Educational, Scientific and Cultural Organization, Technical papers in marine science, v. 44, p. 1-55.

U.S. Fish and Wildlife Service, 2010, Rising to the urgent challenge-Strategic plan for responding to accelerating climate change: U.S. Fish and Wildlife Service, $32 \mathrm{p}$.

Vermeer, M., and Rahmstorf, S., 2009, Global sea level linked to global temperature: Proceedings of the National Academy of Sciences, v. 106, p. 21,527-21,532, doi: 10.1073/pnas.0907765106.

Vogl, R.J., 1966, Salt-marsh vegetation of upper Newport Bay, California: Ecology, v. 47, p. 80-87.

Watson, E.B., and Byrne, R., 2009, Abundance and diversity of tidal marsh plants along the salinity gradient of the San Francisco Estuary-Implications for global change ecology: Plant Ecology, v. 205, p. 113-128, doi: 10.1007/s11258-009-9602-7.

Webb, E.L., Friess, D.A., Krauss, K.W., Cahoon, D.R., Guntenspergen, G.R., and Phelps, J., 2013, A global standard for monitoring coastal wetland vulnerability to accelerated sea-level rise: Nature Climate Change, v. 3, p. 458-465, doi: 10.1038/nclimate1756.

Weis, D., Callaway, J., and Gersberg, R., 2001, Vertical accretion rates and heavy metal chronologies in wetland sediments of the Tijuana Estuary: Estuaries and Coasts, v. 24, p. 840-850.

Zedler, J.B., 1977, Salt marsh community structure in the Tijuana Estuary, California: Estuarine and Coastal Marine Science, v. 5, p. 39-53, doi: 10.1016/0302-3524(77)90072-X. 


\section{Appendixes. Detailed Site-Specific Results}

Appendixes A-G are available for download in PDF format from http://dx.doi.org/10.3133/ofr20161125. 
Publishing support provided by the U.S. Geological Survey Science Publishing Network, Tacoma Publishing Service Center

For more information concerning the research in this report, contact the Director, Western Ecological Research Center U.S. Geological Survey 3020 State University Drive East Sacramento, California 95819 http://www.werc.usgs.gov/ 
